Universidade de São Paulo

Programa de Pós-Graduação em Direito

Departamento de Direito Econômico, Financeiro e Tributário. SubÁrea de Direito Ambiental.

Políticas Públicas Ambientais: ConServação da Biodiversidade e GESTÃo dOS SERVIÇOS ECOLÓGICOS

Dissertação De MeSTRAdo

Discente: Ana Luiza Garcia Campos

Orientadora: Ana Maria de Oliveira de Nusdeo

São Paulo

Agosto de 2013 
Ana Luiza Garcia Campos

\section{Políticas Públicas Ambientais: ConServação da Biodiversidade e GESTÃo dOS SERVIÇOS ECOLÓGICOS}

Dissertação apresentada à Faculdade de Direito da Universidade de São Paulo como requisito à obtenção do título de Mestre em Direito Econômico, Financeiro, Tributário e Ambiental sob a orientação da professora Associada Ana Maria de Oliveira Nusdeo.

Universidade de São Paulo

Faculdade de Direito

São Paulo - 2013 
Banca Examinadora:

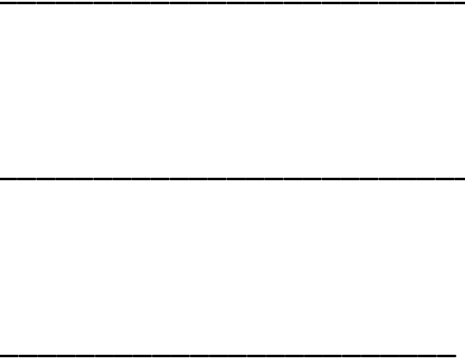




\section{Agradecimentos}

Gostaria de agradecer a cada um que de uma forma ou de outra esteve presente durante este período de estudos.

Primeiramente, a minha orientadora, Profa. Dra. Ana Maria de Oliveira Nusdeo, pela compreensão, pelos ensinamentos, pelas sugestões e críticas, mas acima de tudo pela dedicação e exemplo de profissionalismo.

À Fundação de Amparo a Pesquisa do Estado de São Paulo (FAPESP), agradeço a bolsa de pesquisa conferida para a realização deste mestrado, que permitiu que eu me dedicasse prioritariamente à atividade acadêmica.

Aos demais professores do Programa de Pós-Graduação da Faculdade de Direito e das outras Faculdades da Universidade de São Paulo, pela transmissão de conhecimento, troca de experiências e pela dedicação à docência.

Aos amigos e colegas de mestrado, em especial aos membros do GPDAES, pelas conversas, discussões e sugestões.

A todos os meus amigos, pelas partilhas, pela torcida e especialmente por darem um sentido especial à minha vida.

A todos os meus familiares, em especial às minhas avós Ana e Ivanilde, por suas orações e por se esforçarem em compreender minhas ausências.

Ao Lucas Ferreira, pelo carinho, respeito e companheirismo durante todos estes anos.

Aos meus pais, Fernando e Silvana, por todo amor e dedicação, por sonharem junto comigo.

Aos meus amados irmãos José Eduardo e Maria Gabriela, por serem a razão dos meus melhores sorrisos.

E, sobretudo, a Deus por me amparar nos momentos difíceis, me dar força para superar as dificuldades, iluminar os meus caminho nas horas incertas e me suprir em todas as minhas necessidades. 


\section{Resumo}

A diversidade biológica ao mesmo tempo em que indica possibilidades releva um enorme desafio no desenvolvimento de instrumentos destinados à conservação. A perda e a degradação de habitats, aliadas ao desmatamento e a introdução de espécies exóticas desenham um cenário preocupante, que pode conduzir a homogeneização biótica. A criação de espaços territoriais especialmente protegidos é uma das principais estratégias de conservação da biodiversidade. A lei 9.985/00 sistematizou a legislação sobre as unidades de conservação, mas não solucionou os problemas com a falta de recursos, com os planos de manejo e com a gestão do entorno das unidades. Ainda, em relação aos espaços protegidos, destacam-se as áreas de preservação permanente e reservas legais, destinadas à manutenção de áreas sensíveis e reabilitação de processos ecológicos. O Novo Código Florestal flexibilizou as disposições destes espaços, colocando-os em risco. Lado outro, a conservação de áreas isoladas não é suficiente, é preciso uma visão integrada, na qual as unidades de conservação estejam interligadas ao seu entorno, propiciando usos de terra amistosos com a biodiversidade. Aliados aos instrumentos acima, os pagamentos por serviços ambientais tem o caráter de indutores de comportamento e podem complementar as estratégias de conservação. A efetividade das políticas públicas para a conservação da biodiversidade depende cada vez mais de um mix de instrumentos.

Palavras - Chave: Biodiversidade, Gestão Integrada, Instrumentos de Comando e Controle e de Incentivo Positivo. 


\section{Résumé}

En même temps que la diversité biologique indique des possibilités, elle relève un défi dans Le développement d'instruments destinés à la préservation. La perte et la dégradation d'habitats, conjointement à la déforestation et l'introduction d'espèces exotiques, nous dévoilent un scénario préoccupant, pouvant conduire à l'homogénéisation biotique. La création d'espaces territoriaux spécialement protégés est une des principales stratégies de préservation de la biodiversité. La loi 9.985/00 a systématisé la législation concernant les unités de préservation, mais n'a pas solutionné les problèmes comme le manque de ressources, le plan de maniement, ainsi que la gestion extérieure des unités. De plus, en relation aux espaces protégés, on peut remarquer des zones de préservation permanentes et des réserves légales, destinées à la manutention de zones sensibles ainsi qu'à la réhabilitation de processus écologiques. Le nouveau code forestier a rendu plus flexible les mises à dispositions de ces espaces, les mettant par conséquent en risque. D'un autre côté, la conservation de zones isolées n'est pas suffisante, Il faut en effet, une vision intégrée dans laquelle les unités de conservation soient interconnectées au reste, proportionnant la convivialité des mises à disposition de la terre avec la biodiversité. Associés aux Instruments ci-dessus, Les paiements pour des services environnementaux ont le caractère d'inducteurs de comportements et peuvent complémenter les stratégies de préservation. L'efficacité des politiques pour la préservation de la biodiversité dépend chaque fois plus d'une mixité d'instruments.

Mots- Clé: Biodiversité, Gestion Intégrée, Instruments de Commande et de Contrôle et d'Encouragement positif. 


\section{Lista de Abreviaturas}

ABC - Associação Brasileira Científica

APA - Área de Proteção Ambiental

APP - Área de Preservação Permanente

ARIE - Área de Relevante Interesse Ecológico

CAR - Cadastro Ambiental Rural

CCA - Corredor Central da Amazônia

CCMA - Corredor Central da Mata Atlântica

CDB - Convenção sobre Diversidade Biológica

CNUC - Cadastro Nacional de Unidades de Conservação

CNUMAD - Conferência das Nações Unidas sobre Meio Ambiente e Desenvolvimento CONABIO - Comissão Nacional da Biodiversidade

CONAMA - Conselho Nacional do Meio Ambiente

DETER - Detecção de Desmatamento em Tempo Real

DIPUC - Diagnóstico Participativo em Unidades de Conservação

FUNATRA - Fundação Pró-Natureza

IBAMA - Instituto Brasileiro do Meio Ambiente e dos Recursos Naturais Renováveis

IBDF - Instituto Brasileiro de Desenvolvimento Florestal

ICMS - Imposto sobre Circulação de Mercadorias e Prestação de Serviços

IEF - Instituto Estadual de Florestas

IPEA - Instituto de Pesquisa Econômica Aplicada

MDU - Ministério do Desenvolvimento Urbano e Meio Ambiente 
MFS - Manejo Florestal Sustentável

MMA - Ministério do Meio Ambiente

ONG - Organização não Governamental

PICD - Projetos Integrados de Conservação e Desenvolvimento

PNAP - Plano Estratégico Nacional de Áreas Protegidas

PNUMA - Programa das Nações Unidas para o Meio Ambiente

PRA - Programa de Regularização Ambiental

PROBIO - Projeto Nacional de Ações Integradas Público-Privadas

PRODES - Programa de Despoluição de Bacias Hidrográficas

PROMATA - Programa para Conservação da Mata Atlântica

PSA - Pagamento por Serviços Ambientais

RL - Reserva Legal

RPPN - Reservas Particulares de Patrimônio Natural

SEMA - Secretaria Especial de Meio Ambiente

SEMAD - Secretaria de Meio Ambiente e Desenvolvimento Sustentável

SEMAM - Secretaria de Meio Ambiente da Presidência da República

SISNAMA - Sistema Nacional do Meio Ambiente

SNUC - Sistema Nacional de Unidades de Conservação

UC - Unidades de Conservação

UICN - União Internacional para Conservação da Natureza

UNESCO - Organização das Nações Unidas para a Educação, Ciência e Cultura.

ZEE - Zoneamentos Ecológico-Econômico 


\section{Sumário}

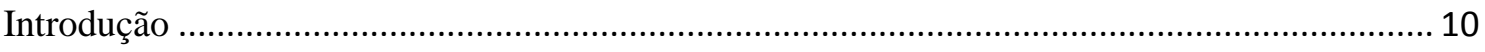

1) Biodiversidade, crise contemporânea e regime jurídico .................................................... 18

1.1)Biodiversidade: conceito, caracterização e ameaças. ..................................................... 18

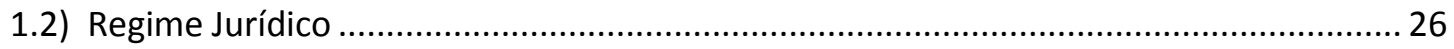

1.2.1) Convenção sobre Diversidade Biológica e Política Nacional sobre Biodiversidade...... 26

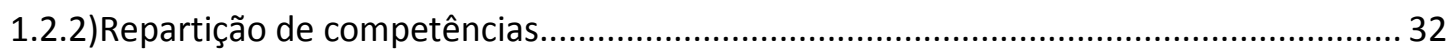

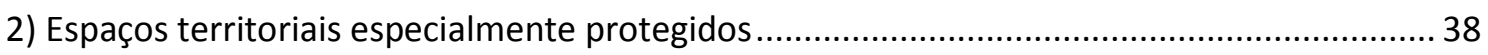

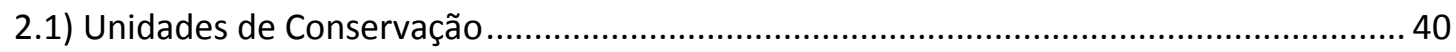

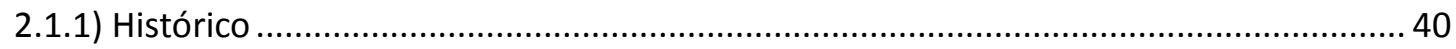

2.1.2) Regime Jurídico das Unidades de Conservação ................................................................ 44

2.1.3) Situação atual e perspectivas para as unidades de conservação .................................. 48

2.2) Código Florestal: Áreas de Preservação Permanente e Reserva Legal ............................ 53

2.1 ) Histórico e Regime Jurídico do Código Floresta de 1965 ................................................ 53

2.2.2) Áreas de Preservação Permanente e Reserva Legal: principais mudanças do Novo

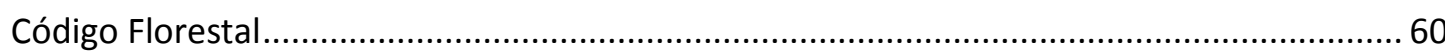

2.2.3) Conclusões e perspectivas para às áreas de preservação permanente e reserva legal71

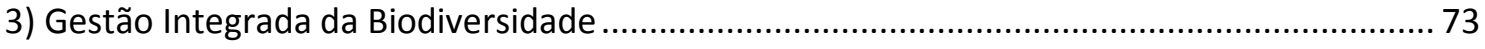

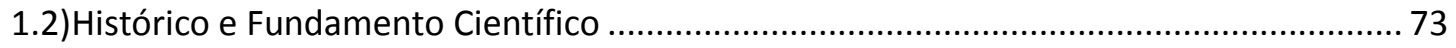

3.2) Corredores, Mosaicos e Reservas de Biosfera …………................................................ 76

3.3) Gestão integrada da biodiversidade: conclusões e desafios ............................................ 83

4) Instrumentos de incentivo posito: pagamento por serviços ambientais.............................. 85

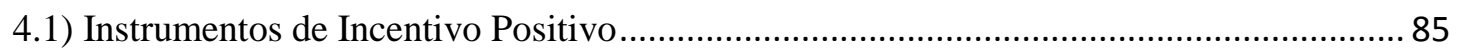

4.2) Serviços Ambientais: Introdução, Definição e Caracterização......................................... 89

4.3) Contribuições das escolas econômicas .......................................................................... 92

4.4) O que é necessário para o pagamento por serviços ambientais ...................................... 96

4.5) Pagamentos por serviços ambientais para conservação da biodiversidade ...................... 98

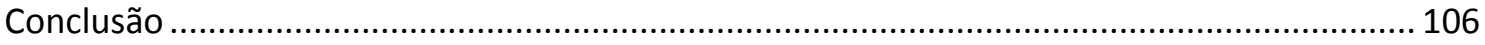

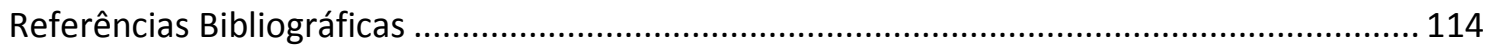




\section{Introdução}

A realização desta pesquisa nasceu da ideia de que, sendo o Brasil o país mais biodiverso do mundo, cabe ao Poder Público e a Academia ampliar a compreensão sobre a importância do patrimônio biológico nacional e o conhecimento da legislação e das políticas públicas destinadas a sua conservação.

A dificuldade em trazer à realidade a realização do desenvolvimento sustentável, somada à facilidade com que algumas pessoas e instituições apropriam-se do termo para legitimar suas atividades, levou muitas pessoas a duvidar do próprio conceito. Aparte as ilusões ou desilusões em demasia, o desenvolvimento sustentável é, antes de tudo, um desafio.

Para analisar as questões propostas se faz necessário uma visão ou análise transdiciplinar em que se congreguem aspectos jurídicos, econômicos biológicos, todos em torno de assegurar, na prática, a sustentabilidade.

O caráter complexo e multidimensional do termo impede que o desenvolvimento seja encapsulado em fórmulas simples. Por isso mesmo, o conceito evolui ao longo do tempo, incorporando experiências positivas e negativas. Evolução essa que se dá, em grande medida, a partir das próprias discussões sobre o conceito e em contraposição com o balanço negativo do desenvolvimento real em diferentes lugares do mundo. Daí a importância de reavaliar sempre a realização do desenvolvimento, objetivando torná-la mais operacional e reafirmar sua centralidade.

Por estas razões pensar em políticas públicas que sejam capazes de garantir a conservação da biodiversidade requer ponderar alguns dos instrumentos já existentes dando-lhes novos contornos, bem como, buscar novas alternativas ou mesmo a articulação de velhas e novas estruturas.

Em face da importância da temática a pergunta de pesquisa que norteou este trabalho foi: como se desenvolveram e qual a situação atual dos instrumentos de políticas públicas para a conservação da biodiversidade?

A proposta do trabalho é fazer um diagnóstico do estado em que em se encontram os instrumentos de políticas públicas para conservação da biodiversidade, resgatando seus objetivos e fundamentos através de seu histórico, confrontando estes objetivos com a legislação atual e com dados secundários sobre sua situação 
contemporânea e a partir destes pressupostos traçar mesmo que de maneira singela suas perspectivas.

Para efeitos de delimitação do tema, já que o escopo acima é por demais abrangente, optou-se por trabalhar com os instrumentos de conservação da biodiversidade terrestre ligados à vegetação. Prosseguindo com mais um corte metodológico se restringiu a pesquisa aos instrumentos ligados à conservação por área conservada que possuem como um de seus principais objetivos a conservação da biodiversidade ou dos serviços ecossistêmicos. Dentre estes últimos foram escolhidos aqueles que possuíam maior relevância e que a priori são universais, chegou-se desta forma às unidades de conservação, as áreas de preservação permanente e reserva legal, aos instrumentos de gestão integrada da biodiversidade e aos instrumentos de incentivo positivo ligados à biodiversidade.

Este trabalho possui como objetivo geral a discussão da disciplina legal relacionada a estes instrumentos de conservação da biodiversidade. Dentre os objetivos específicos pode-se destacar a análise da relação de complementaridade entre os instrumentos de comando e controle e os instrumentos econômicos.

A pesquisa levada a efeito, conforme consta no plano de trabalho, consistiu em larga medida no levantamento de fontes bibliográficas e análise do conteúdo destas.

Utilizou-se de uma gama de dados secundários advindos de fontes oficiais. Embora, este recurso não seja tão frequente nas pesquisas em Direito, no presente caso mostrou-se fundamental para a consecução da pesquisa. Já que a partir deste foi possível visualizar a situação atual de vários instrumentos e inferir seus desafios.

Neste sentido, a discussão buscou: contemplar os fundamentos científicos e os valores que sustentam as normas de conservação da biodiversidade; mostrar como a biodiversidade está inserida na Constituição Federal; apontar as leis que tratam da conservação biodiversidade dentro do espectro delimitado; mostrar como foi o processo histórico e construção das normas nacionais e internacionais sobre a matéria; discutir e expor a situação atual das unidades de conservação, dos instrumentos de gestão integrada da biodiversidade e dos instrumentos de incentivo positivo.

Antes, porém, é preciso tratar de alguns aspectos gerais sobre as políticas públicas direcionadas à conservação da diversidade biológica e sobre a interação entre seus instrumentos. 
Refletir sobre as políticas públicas, de maneira geral, denota raciocinar sobre as instituições de uma sociedade, significa pressupor a existência de um interesse comum que consolide e justifique a existência dessas mesmas instituições.

Alargar o bem estar social exige a confecção de planos gestores que visem à mitigação de conflitos e aquisição de ganhos, o que deverá resultar na obtenção do interesse comum. Ao Estado cumpre empenhar-se para alcançar os fins da sociedade, sejam eles no campo da educação, saúde, previdência ou conservação do meio ambiente, por exemplo.

A existência de múltiplas demandas e de uma série de conflitos sociais, e consequentemente, a pressão para solução destes formará agendas, no âmbito dos Estados. A maneira com que estes conflitos são percebidos difere a depender dos gestores públicos e isto fixará a agenda de diferentes formas. Fixadas as agendas, estas farão surtir programas de governo que, por fim, tornar-se-ão políticas públicas a partir do momento em que forem institucionalizadas, atravessando várias etapas.

Chamar atenção para as políticas públicas direcionadas à biodiversidade faz-se importante vez que a crise da biodiversidade crescentemente conhecida pela ciência, nem sempre é reconhecida ou mesmo conhecida por todos os setores da sociedade.

Para se avaliarem os aspectos éticos, políticos e econômicos dessa crise, é necessário ter consciência dos prejuízos da perda de biodiversidade e da destruição dos ecossistemas e como se distribuem os passivos a curto, médio e longo prazos.

Ela recai com diferentes magnitudes e de maneiras diferentes os diversos setores da sociedade, altera a repartição de poder político e da riqueza econômica. Ela atinge mais duramente alguns setores sociais do que outros; pode acentuar injustiças sociais e causar desigualdades socioeconômicas.

Com o passar do tempo, todos são afetados pela perda de resiliência e capacidade de suporte dos ecossistemas. Há menor segurança para as futuras gerações. Torna-se mais necessária a capacidade de adaptação e de controle, em relação a ameaças emergentes; cresce o esgarçamento de cadeias alimentares. Aumentam custos para a sobrevivência humana e para a saúde, pois as avarias de hábitats provocam a propagação de doenças como chagas, malária, febre amarela. As perdas de biodiversidade geram um risco adicional para aqueles que já eram anteriormente vulneráveis e robustecem a importância da ação cooperativa.

De início, cabe destacar que as políticas públicas desenvolveram-se, originalmente, como área do conhecimento da ciência política, passando a adquirir 
autonomia a partir da metade do século vinte, com desdobramentos de trabalhos que, nos Estados Unidos enfocavam a ação dos governos, e na Europa privilegiavam a questão do papel do Estado e suas instituições, dentre elas, o governo (RODRIGUES, 2010, p. 29). Embora atualmente como fenômeno multidisciplinar, a análise e compreensão das políticas públicas necessitam do diálogo entre a ciência política, a ciência da administração, a economia, o direito, entre outros campos do conhecimento (BUCCI, 2008, p. 226).

Em razão de afetarem vários aspectos de nossa vida cotidiana, vez que extraem dinheiro da sociedade pelos tributos, regulam comportamentos e conflitos, organizam mercados e burocracias bem como, por dizerem respeito à ação ou inação dos governos o estudo sobre políticas públicas vem despertando interesses, principalmente porque ajudam a compreender melhor a sociedade, mas também porque auxiliam no entendimento das causas e consequências das decisões públicas. De acordo com Marta Assumpção “ entender melhor as causas consequências das decisões públicas significa também avaliar se as políticas que estão sendo adotadas num determinado momento e num determinado contexto, estão, de fato atingindo os alvos certos" (RODRIGUES, 2010, p.29).

A expressão políticas públicas é multívoca em razão das várias dimensões do fenômeno social que busca definir. Desta feita, as definições encontradas variam conforme o enfoque teórico eventualmente adotado, e o respectivo contexto social e político (BUCCI, 2008, p. 28).

O que se verifica é que quando são apresentadas definiçõoes para as políticas públicas percebe-se que elas tendem a focalizar o Estado ou as ações de governos. Vejamos alguns exemplos: para Eros Grau políticas públicas são "todas as atuações do Estado, cobrindo todas as formas de intervenção do Poder Público na vida social" (MASSA-ARZABE, 2006, p.75). Para Maria Paula Dallari Bucci é o programa de ação governamental que resulta de um processo ou conjunto de processos juridicamente regulados- processo eleitoral, processo orçamentário, processo legislativo, processo administrativo, processo judicial- visando coordenar os meios à disposição do Estado e as atividades privadas, para a realização de objetivos relevantes e politicamente determinados (BUCCI, 2006, p. 39).

Por fim, para Marta Assumpção políticas públicas “constituem um conjunto articulado de ações decisões e incentivos que buscam alterar a realidade em resposta a demanda e interesses envolvidos. Essas ações são desencadeadas por atores que lidam 
com algum problema público e são desenvolvidas por instituições públicas governamentais pelo processo político(legislativo, judiciário, tribunais de contas, ministério público etc.) que as condicionam. O objetivo é assegurar que o desempenho dessas instituições esteja a serviço do interesse público e submetido ao controle democrático" (RODRIGUES, 2010, p.52).

As diferentes visões e abordagens, no entanto, não devem ser tidas como excludentes, pois, ao focarem distintos aspectos do tema, permitem a sua melhor compreensão.

Outro aspecto que merece atenção e é destacado por diversos autores cinge-se à necessidade das políticas públicas possuírem objetivos e metas. Maria Paula Dallari Bucci aduz que: "como tipo ideal, a política pública deve visar à realização de objetivos definidos, expressando a seleção de prioridades, a reserva de meios necessários à sua consecução e o intervalo de tempo que se espera o atingimento dos resultados" (BUCCI, 2006, p. 39).

Estudar políticas públicas na seara ambiental não é uma tarefa simplista, pois envolve um grande número de atores sociais que necessitam da organização e força de um ente maior e legítimo. Ademais, adotar decisões dentro desta temática, pressupõe conhecimento científico do problema e suas possíveis consequências. Motivo pelo qual, muitas das vezes o único disposto a arcar com os custos deste conhecimento prévio e necessário é apenas o Estado.

Por estas razões pensar em políticas públicas que sejam capazes de garantir a conservação da biodiversidade requer um processo contínuo de avaliação dos instrumentos, dando-lhes novas roupagens quando necessário ou criando novos quando as situações assim demandarem.

O aparelhamento do Estado para a gestão do meio ambiente exige a edição de instrumentos de políticas eficazes para o cumprimento da tarefa constitucional de conservar os recursos naturais para as presentes e futuras gerações.

No Brasil, os gestores de políticas públicas fazem uso de vários instrumentos de política ambiental enumerados pela Lei nº 6.938 de 1981 (PNMA), cujo objetivo é a preservação, melhoria e recuperação da qualidade ambiental propícia à vida.

No entendimento de Junqueira et. al. (MAY, 2010, p.163-164) instrumentos de política ambiental são conjuntos de ações voltados para a redução dos impactos negativos da ação antrópica sobre o meio ambiente. 
Os principais instrumentos de política ambiental, classificados pela doutrina, dividem-se em dois grupos: instrumentos de comando e controle, também conhecidos como regulatórios e instrumentos econômicos, também conhecidos como instrumentos de incentivo positivo.

Os instrumentos de comando e controle são mecanismos por meio dos quais o poder público estabelece padrões, monitora a qualidade ambiental e regula as atividades aplicando sanções por meio da legislação, há a edição de lei específica para regulamentar o uso e acesso aos recursos naturais.

No caso específico da biodiversidade o instrumento de comando e controle que mais tem sido mais utilizado é a criação de espaços territoriais especialmente protegidos como unidades de conservação, áreas de preservação permanente e reserva legal, pelo Poder Público federal, estadual e municipal (art. 9º VI, Lei 6938/81). Contudo, a escassez de recursos humanos e financeiros da administração pública para arcar com a fiscalização e sanção pelo descumprimento da norma tem gerado a falta de efetividade destes instrumentos.

Neste sentido o uso de instrumentos de incentivo positivo tem crescido nos últimos anos, este fato teria como razão a insuficiência do uso isolado de instrumentos de comando e controle para assegurar os resultados esperados das políticas ambientais. A Lei 6.938 de 1981 também dispõe sobre a utilização dos mesmos.

Os Instrumentos econômicos são aqueles que atuam diretamente nos custos de produção e consumo dos agentes cujas atividades estejam inseridas nos objetivos da política em questão. Os exemplos são os tributos em geral e os preços públicos, que podem ser criados, majorados ou reduzidos, assim como a criação de mecanismos de mercado para transações no âmbito dos limites legais de utilização dos recursos naturais, além dos pagamentos por serviços ambientais que apresentam potencialidade de uso para promover a conservação da biodiversidade.

O reconhecimento econômico das funções ambientais como valiosas e escassas ao bem-estar humano tem conduzido os esforços para valorizar os serviços ambientais através de esquemas que visam sua remuneração, mas que não se restrinjam aspectos exclusivamente monetários.

Lado outro, a partir de uma visão sistêmica da conservação biodiversidade e da necessidade de se evitar a perda e a fragmentação cada vez maiores de habitats a gestão integrada da biodiversidade tem chamado atenção na medida em que busca articular 
áreas públicas e privadas através da criação de corredores, mosaicos e reservas de biosfera.

Vê-se, pois, que a conservação da biodiversidade, representada pelo desafio de preservação da biodiversidade e serviços ecossistêmicos demanda cada vez mais um mix de políticas públicas por meio da conjugação de vários instrumentos de política ambiental.

O conceito de policymix é definido, de modo geral, como uma combinação de instrumentos de política construída com o objetivo de influenciar quantitativa qualitativamente na conservação da biodiversidade, além de sustentar o fornecimento dos serviços ecossistêmicos no setor público e privado (RING \& SCHRÖTER-SCHLAACK, 2011, apud BORGES, ANDRADE, 2011, p.8).

Dado a conservação da biodiversidade é essencial para a continuidade das condições de vida na Terra, os instrumentos de política devem ser o mais eficaz possível, no sentido de garantir a real proteção da biodiversidade e dos benefícios dela proveniente. Não basta apenas aplicá-los, mas também se deve procurar meios para que os mesmos sejam eficientes sob o ponto de vista ecológico, econômico e social.

Dada a heterogeneidade, causada pelo natural complexo adaptativo da diversidade biológica dos ecossistemas, exige-se uma gama de múltiplos instrumentos capazes de abordar diferentes aspectos da perda de biodiversidade e a questão da degradação dos ecossistemas. Ainda devido à complexidade inerente da biodiversidade e dos ecossistemas existem lacunas de informação. Assim, a ignorância, as incertezas e as falhas de informação têm grande importância para o princípio da precaução, mantendo um padrão mínimo de políticas para conservação para evitar grandes irreversibilidades, pois não existe um instrumento único e ideal para este domínio político. No âmbito de incertezas, um mix de instrumentos de políticas garante, com maior eficácia e eficiência, a proteção da biodiversidade, pois abordam vários objetivos, várias estratégias, reduzindo riscos de fracassos e a incerteza gradualmente, dificultando a tomada de decisão (ANDRADE, BORGES, 2011, p.9-13).

A fim de se alcançar o escopo delimitado nas primeiras linhas desta introdução e a vista do referencial teórico traçado logo em seguida, o presente trabalho articula-se da seguinte maneira:

No primeiro capítulo caracteriza-se e discuti-se o conceito de biodiversidade, as principais ameaças com especial atenção á fragmentação de habitats e ao desmatamento. A fim de se entender como a temática da biodiversidade se insere no ordenamento 
jurídico brasileiro traça-se um paralelo entre a Convenção sobre Diversidade Biológica e a Política Nacional sobre Biodiversidade, seus órgãos e atribuições, destacando o papel das metas e a repartição de competências dos órgãos e entidades ligados à conservação da biodiversidade, através de um resgate histórico.

A partir do segundo capítulo passa-se a tratar efetivamente dos instrumentos que interferem nos usos de terras. Inicia-se pelos espaços territoriais especialmente protegidos e seu arcabouço constitucional. Em relação às unidades de conservação com a finalidade de buscar seus fundamentos fez-se uma breve digressão histórica. Tratou-se a seguir do regime jurídico, dos desafios e perspectivas para estas áreas.

As áreas de preservação permanente e reserva legal foram alvos atualmente de intensos debates, assim, busca-se mesmo que de maneira incipiente analisar as principais mudanças e consequências advindas do Novo Código Florestal, sem, contudo, deixar de lado seus fundamentos e antecedentes.

Ao lado dos instrumentos acima no terceiro capítulo trata-se da gestão integrada da biodiversidade, de seus fundamentos científicos, de seu papel na conectividade das áreas e da mudança de paradigma que ela representa para a conservação da biodiversidade.

No quarto capítulo com base na teoria das sanções premiais do Direito discuti-se a utilização dos instrumentos de incentivo positivo na conservação da biodiversidade. Dentre os instrumentos de incentivo positivo destacam-se os pagamento por serviços ambientais em razão de sua flexibilidade e capacidade de acomodação a cada realidade. Discorre-se sobre sua fundamentação teórica e necessidades práticas.

Por fim, analisa-se o PROMATA (Programa para Conservação da Mata Atlântica) que exemplifica a articulação entre os instrumentos para a conservação da biodiversidade discutidos neste trabalho, amoldando-se e caracterizando-se como um mix de políticas. 


\section{1) Biodiversidade, crise contemporânea e regime jurídico}

\section{1) Biodiversidade: conceito, caracterização e ameaças.}

O termo biodiversidade é um conceito relativamente recente, mas que recebeu definição oficial com a Conferência das Nações Unidas sobre Meio Ambiente e Desenvolvimento (CNUMAD), realizada em 1992 no Rio de janeiro, ocasião em que foi acordada a Convenção sobre Diversidade Biológica (CDB). De acordo com a CDB e com a Lei ${ }^{\circ} 9.985$ de 18 de julho de 2000 (Lei do Sistema Nacional de Unidade de Conservação - SNUC), que utiliza conceito semelhante, biodiversidade ou diversidade biológica significa:

\footnotetext{
a variabilidade de organismos vivos de todas as origens, compreendendo, dentre outros, os ecossistemas terrestres, marinhos e outros ecossistemas aquáticos e os complexos ecológicos de que fazem parte; compreendendo ainda a diversidade dentro de espécies, entre espécies e de ecossistemas.
}

Verifica-se então, a existência de três níveis de biodiversidade, o primeiro refere-se à diversidade de ecossistemas, representado pela diversidade de combinações únicas da diversidade de organismos e ambientes e suas relações que formam os diferentes ecossistemas, o segundo pela diversidade de espécies consideradas individualmente e o terceiro pela diversidade genética, formado pela diversidade de genes dentro de cada espécie, e pela diversidade de suas combinações em cada espécie.

Edward O. Wilson (2012) destaca dois sistemas por meio dos quais se podem estudar a diversidade biológica, estes sistemas facilitam a compreensão do conceito acima.

O primeiro deles, conhecido como sistema taxionômico compreende uma escala de grupos de seres vivos com características comuns, hierarquizada conforme graus de semelhança entre si. A unidade mínima do sistema é a espécie, seguida de unidades cada vez mais abrangentes, como gênero, família, ordem, classe, filo e reino. 
"Descrever a diversidade organizando as espécies em grupos de acordo com o quanto elas se assemelham umas às outras foi um avanço fundamental da biologia do século XVIII" (WILSON, 2012, p.196) mas avançou-se ao criar outra forma igualmente importante baseada nos níveis de organização biológica.

Os níveis organizacionais estão dispostos com a seguinte hierarquia: ecossistema, comunidade, guilda, espécie, organismo, gene.

Como dito anteriormente, o termo biodiversidade, conforme definido na Convenção sobre Diversidade Biológica (CDB) e na Lei do SNUC, abrange esses dois sistemas descritos por WILSON (2012), vez que compreende não só riqueza de espécies, mas também os seus níveis de organização ecológica.

O Brasil é um dos dezessete países que é considerado megadiverso. Nosso território abriga entre $15 \%$ e $20 \%$ de toda a biodiversidade do planeta e o maior número de espécies endêmicas, a maior floresta tropical (a Amazônia) e dois dos dezenove hotspots mundiais (a Mata Atlântica e o Cerrado). A riqueza biológica nacional manifesta-se também na diversidade de ecossistemas: são seis biomas continentais Amazônia, Cerrado, Mata Atlântica, Caatinga, Pantanal e Pampa -, que abrangem dez regiões fitoecológicas e 31 formações vegetais, entre florestas, savanas e estepes. Somam-se, ainda, as áreas de formações pioneiras, de influência marinha, fluvial e lacustre, como restingas e mangues, importantes berçários naturais, e, também, as de tensão ecológica, isto é, de contato entre diferentes regiões ecológicas. (CÂMARA DOS DEPUTADOS, 2011,p.7).

De fato, a formidável riqueza da diversidade biológica brasileira, ao mesmo tempo em que indica possibilidades traduz-se em enormes dificuldades, seja no trabalho a desenvolver no campo do conhecimento, seja para preservar e conservar essa diversidade biológica, que sofre intensos impactos decorrentes do processo socioeconômico no país.

O Ministério do Meio Ambiente nos anos de 2004 a 2007 através do Projeto para a Conservação e Uso Sustentável da Diversidade Biológica Brasileira - PROBIO promoveu um estudo direcionado para o mapeamento da cobertura vegetal por bioma, (MINISTÉRIO DO MEIO AMBIENTE, 2011, p.22). Referido estudo permitiu aferir situação dos principais tipos de vegetação dentro de cada bioma.

Desta feita, verificou-se em resumo que em 2004 o Brasil tinha 27,75\% (aproximadamente $2.356 .065 \mathrm{~km}^{2}$ ) de seu território alterados por uso humano (agricultura, áreas urbanas, desmatamento e outros). De 2004 a 2006 essa porcentagem 
aumentou para aproximadamente 30\%), deixando cerca de $70 \%$ do território nacional ainda coberto de vegetação original em graus variados de conservação, (MINISTÉRIO DO MEIO AMBIENTE, 2011, p.24).

O bioma da Mata Atlântica é mais alterado (70,95\%) dos biomas terrestres, seguido pelo Pampa que também está severamente modificado pelo uso humano $(48,70 \%)$, particularmente por atividades pecuárias e plantações florestais e pelo Cerrado cuja vegetação, em graus variados de conservação, cobre $60,42 \%$ do bioma no Brasil, (MINISTÉRIO DO MEIO AMBIENTE, 2011, p. 23, 24).

No que tange ao estado de conhecimento da biodiversidade brasileira, resultados publicados no ano de 2006 indicam que, considerando as possíveis necessidades de revisão taxonômica, pelo menos 103.870 espécies animais e 43.020 espécies vegetais ocorrem no Brasil. Em média, 700 novas espécies animais são reconhecidas por ano no Brasil. Aproximações estimam que a biodiversidade brasileira é cerca de dez vezes a que hoje é registrada: quase 2 milhões de espécies esperadas contrastando com cerca de 200 mil conhecidas. (MINISTÉRIO DO MEIO AMBIENTE, 2006, p.34). Verifica-se, portanto que ao lado de toda essa riqueza, os problemas são igualmente de grande magnitude tanto na sistematização do conhecimento e sua disseminação quanto na busca de práticas que sejam capazes de combater as ameaças à biodiversidade.

De acordo com estudos do Ministério do Meio Ambiente, "a perda e a degradação de habitat são as principais causas de ameaça à biodiversidade brasileira. A expansão agrícola e o desmatamento são fatores importantes contribuindo para esse cenário, particularmente quando combinados com outras causas principais da perda de biodiversidade, tais como a introdução voluntária e involuntária e a propagação de espécies exóticas invasoras, o uso do fogo para limpar terrenos, a poluição e contaminação da água e do solo e a fragmentação de habitats". (MINISTÉRIO DO MEIO AMBIENTE, 2011, p.46).

O câmbio de habitat nativos para usos alternativos tem desenhado o território brasileiro. As terras são normalmente destinadas para agricultura, pecuária, aquicultura, mineração, urbanização, ou são simplesmente abandonadas quando já estão degradadas e inservíveis. Nas áreas florestais, dependendo da fertilidade inicial do solo, ocorre o que se pode denominar ciclo típico, que envolve a extração madeireira, o desmatamento e queimada, cultivos anuais ou de produtos para exportação (café, cacau, algodão, laranja, etc.), cultivos semi-perenes resistentes (como a cana de açúcar), 
pastagens, seguido de abandono da atividade, deixando as terras ora ocupadas, degradadas e sem uso. (UICN, WWF-BRASIL, IPÊ, 2011, p.21,22).

No ano de 2004, 27,75\% (aproximadamente 2.356.065 km²) do território do Brasil havia sido alterado pelo uso humano (áreas agrícolas e urbanas, desmatamento, outros). O censo agropecuário do ano $2006^{1}$ indicou um total de $2.549 .799 \mathrm{~km}^{2}$ do território nacional ocupado por atividades agropecuárias, incluindo pastagens naturais e plantadas. Verifica-se ainda, que nas últimas três décadas, ocorreu no Brasil um crescimento explosivo na produção agrícola, sem paralelo em nenhum outro país. O Brasil é atualmente um dos líderes mundiais na produção e exportação de café, açúcar, suco de laranja, soja, carne bovina e frango, entre outros produtos agrícolas. Vê-se que embora a tecnologia agrícola tenha se aperfeiçoado, permitindo o incremento da produção sem necessariamente aumentar a área ocupada pela produção, a conversão de terras em pastagens e lavouras permanece sendo um fato relevante para modificação, fragmentação e perda de habitat. (MINISTÉRIO DO MEIO AMBIENTE, 2011, p.47).

Muitas espécies originárias de outros países ocorrem atualmente no Brasil. Por espécies exóticas entendem-se todas aquelas que estão fora de sua natural (original), área de distribuição. Algumas espécies exóticas se multiplicam de forma invasiva e afetando os ambientes terrestres e aquáticos, a saúde humana e a economia. O impacto mais corriqueiro causado por essas espécies é a competição com espécies nativas, mas os organismos invasores também aumentam a predação sobre espécies nativas; reduzem a disponibilidade de habitat e modificam a fisionomia dos habitats; causam perdas econômicas; alteram o regime hídrico em rios e riachos e causam alterações físicoquímicas no ambiente; trazem novas doenças para o país; e em alguns casos levam espécies nativas à extinção. (MINISTÉRIO DO MEIO AMBIENTE, 2011, p.48).

Um diagnóstico das espécies exóticas invasoras atuais e potenciais foi realizado em 2005 dentro do projeto PROBIO que verificou que de 171 espécies exóticas invasoras identificadas, $76 \%$ foram introduzidas propositalmente no país (ou em um bioma diferente de sua distribuição original), na maior parte com objetivos econômicos. Exemplos dessas espécies são o caramujo gigante africano (Achatina fulica), javali (Sus scrofa) e o capim anone (Eragotis plana). A importação de plantas de uso ornamental e de animais de estimação é a principal causa de introdução de espécies exóticas (24\%).

\footnotetext{
${ }^{1}$ Para maiores informações consultar: http://www.ibge.gov.br/home/estatistica/economia/agropecuaria/censoagro/2006/agropecuario.pdf. Acesso: 09 de abril de 2013.
} 
Programas de melhoramento genético de forrageiras foram responsáveis por $13 \%$ de espécies invasoras, e os de uso florestal por 9\% (PROBIO, 2005, citado por MINISTÉRIO DO MEIO AMBIENTE, 2011, p. 47-48).

A dispersão de espécies exóticas contribui para a homogeneização dos ambientes, com a destruição de características peculiares que a biodiversidade local e proporciona a modificação nas propriedades ecológicas essenciais.

Em ecossistemas pobres em nutrientes, a presença de espécies invasoras propicia condições favoráveis para o estabelecimento de outras espécies invasoras, que normalmente não se estabeleceriam. As plantas invasoras, em seu processo de ocupação, aumentam sua área de ocorrência e dominam a flora nativa por competição direta. Os animais deixam a área à procura de alimentos, antes abundantes pela diversidade de espécies existentes. Desta forma, mesmo que devagar as invasões biológicas vão promovendo a substituição de comunidades com elevada diversidade por comunidades monoespecíficas, compostas por espécies invasoras, ou com diversidade reduzida (Resolução CONABIO. n ${ }^{\circ} 5$ de 21 de outubro de 2009, Anexo,p.3).

Faz-se importante considerar que o custo de controle e manejo de espécies exóticas invasoras em um novo ambiente é alto. Assim, ações de prevenção de futuras introduções devem ser estimuladas e podem evitar a perdas significativas à floresta, aos ecossistemas naturais e manejados e à saúde humana. Ao revés de muitos problemas ambientais que tendem a se amenizar com o passar do tempo, a contaminação biológica, caso não sejam tomadas medidas de prevenção, tende a se multiplicar e se espalhar, ocasionando problemas de longo prazo que se agravam dificultando a recomposição natural dos ecossistemas afetados. Essas deteriorações ambientais põem em risco atividades extrativistas e as demais atividades econômicas relacionadas ao uso dos recursos naturais.

Em razão da complexidade dessa temática, a Comissão Nacional de Biodiversidade - CONABIO aprovou a Resolução CONABIO nº 05, de 21 de outubro de 2009 que dispõe sobre a Estratégia Nacional sobre Espécies Exóticas Invasoras², que trata em sua maioria de medidas de prevenção. Acrescenta-se a este fato, as metas do Brasil relacionadas ao tema, quais sejam: todas as espécies no Diagnóstico Nacional de Espécies Exóticas Invasoras com plano de ação de prevenção e controle elaborado e

\footnotetext{
${ }^{2}$ Disponível em:

http://www.mma.gov.br/estruturas/174/_arquivos/anexo_resoluoconabio05_estrategia_nacional_espcies __invasoras_anexo_resoluoconabio05_174.pdf
} 
planos de manejo implementados para controlar pelo menos 25 das principais espécies exóticas invasoras que mais ameaçam os ecossistemas, habitat ou espécies no país.

Ainda como ameaças à biodiversidade pode-se destacar o desmatamento. De acordo com Milaré (2009, p.1302) desmatamento é "a destruição, corte ou abate indiscriminado de matas e florestas, para comercialização de madeira, utilização do terreno para agricultura, pecuária, urbanização, qualquer outra atividade econômica ou obra de engenharia".

A partir do conceito acima, pode-se observar que o desmatamento é um fenômeno com pluralidade de causas e consequências que variam conforme o contexto histórico, político e econômico vigente, é por assim dizer causa e/ou consequência de uma série de outras ameaças à biodiversidade.

O desmatamento tem impacto direto na biodiversidade já que ambientes atingidos dificilmente podem ser restaurados em completude e retornar ao seu estado anterior, bem como afeta o regime de chuvas, a qualidade do solo e influência nas mudanças climáticas.

Um estudo realizado pelo Instituto de Pesquisa Econômica Aplicada (IPEA) em 2001 estimou o custo econômico do desmatamento na Amazônia em US\$ 108,1 por hectare por ano, quantia suficiente para financiar o uso sustentável de uma vasta porção da Região Amazônica. Este cálculo levou em consideração o valor direto e indireto, tais como o fornecimento de recursos extrativistas e serviços ambientais; e o valor opcional e intrínseco do uso futuro de recursos genéticos e da existência de espécies não humanas, assim como fatores externos ( MOTTA, 2001 citado por MINISTÉRIO DO MEIO AMBIENTE, 2011, p.55).

Várias formas de monitoramento tem sido desenvolvidos para impedir o desmatamento nos biomas brasileiros como o PRODES e o DETER para a Amazônia, por meio de sensoriamento remoto e geoprocessamento com imagens de satélite na Mata Atlântica e no Cerrado. Salienta-se, contudo, a necessidade de monitoramento dos demais biomas do país.

Conjuntamente com os desmatamentos as queimadas e incêndios florestais tomam grandes proporções no país são mais 300 mil focos de queimadas por ano. Normalmente a queimada é tida como prática agrícola usual, utilizada para o controle de pragas e limpeza da área para o plantio. Apesar de a primeira vista facilitar a vida do agricultor, com tempo as queimadas geram o empobrecimento do solo, a deterioração da 
qualidade do ar e afetam a dinâmica dos ecossistemas ${ }^{3}$.Neste sentido ações voltadas a estimular e disseminar as alternativas ao uso do fogo devem ser promovidas.

Por fim, tratar-se-á da fragmentação de habitats, tema que será recorrente neste trabalho em razão da sua importância e de suas consequências para a biodiversidade.

A fragmentação de habitats é uma das mais importantes e difundidas consequências da atual dinâmica de uso da terra pelo homem. Nas últimas duas décadas, a pesquisa em conservação produziu um volume importante de conhecimentos sobre os efeitos dos vários tipos de uso da terra sobre a persistência das espécies, organização das comunidades e funcionamento dos ecossistemas.

Fragmentação em sentido comum é o procedimento de separar um todo em partes, fragmento é consequentemente uma parte retirada de um todo. No contexto desta dissertação, considera-se fragmentação como sendo a divisão em partes de uma dada unidade do ambiente, partes estas que passam a ter condições ambientais diferentes em seu entorno. A fragmentação é, portanto, o processo no qual um habitat contínuo é dividido em manchas, ou fragmentos, mais ou menos isoladas, em decorrência principalmente da retirada da vegetação nativa (CERQUEIRA et. al., 2003).

Quando o habitat é destruído, fragmentos de habitat comumente são deixados para trás. Estes fragmentos normalmente ficam isolados uns dos outros, por uma paisagem altamente modificada ou degradada. Esta situação pode ser descrita pelo modelo de biogeografia de ilhas, com os fragmentos funcionando como ilhas de habitat em um "mar" ou matriz inóspita dominada pelo homem. A fragmentação ocorre mesmo quando a área do habitat não é tão afetada como no caso do habitat original ser dividido por estradas, ferrovias, linhas de energia, entre outro (PRIMACK, RODRIGUES, 2001, p. 95). Considera-se que as manchas isoladas tendem ao empobrecimento de espécies.

Os fragmentos de habitat diferem do original de duas maneiras: os fragmentos tem uma quantidade maior de borda por área de habitat e o centro de cada fragmento está mais próximo dessa borda (PRIMACK, RODRIGUES, 2001, p. 95).

Habitats fragmentados ou ilhas de habitats podem ser gerados por causas naturais ou produzidos pela ação antrópica.

A identificação dos fatores antrópicos que interferem no processo de fragmentação ambiental não é um trabalho fácil. Quando se busca prever e avaliar as suas consequências, defronta-se com parcas bases empíricas em escalas não compatíveis

\footnotetext{
${ }^{3}$ Informações disponíveis em: < http://www.ibama.gov.br/areas-tematicas/alternativas-ao-uso-do-fogo.> Acesso em: 17.05.2013
} 
com os fenômenos que são observados e com a pouca prática do monitoramento permanente (FISZON et al. 2003, p.67).

A fragmentação produzida pelo homem possui como características a sua ocorrência em grande escala de espaço numa pequena escala de tempo. Durante o processo, as manchas de habitat remanescentes podem desfavorecer as espécies cujas manchas tenham sido destruídas em maior quantidade, desta forma perde-se diversidade ocasionando a perda de grupos funcionais em muitos lugares. A alteração dos ecossistemas também pode levar à perda de muitos serviços ecossistêmicos com consequências deletérias tanto no médio quanto no longo prazo.

Têm-se, pois, que em processo contínuo de conversão da paisagem nativa em áreas antropizadas, a perda de espécies ocorre não apenas imediatamente após a remoção da vegetação nativa, mas continua nos fragmentos, especialmente naqueles menores e mais isolados, em que as populações ficam mais vulneráveis a extinção (RAMBALDI; OLIVEIRA, 2003).

Esses impactos, sofridos pelas espécies ocorrentes nas áreas mais externas dos fragmentos florestais, em contato com o hábitat alterado, denominam-se efeito de borda. Diversos fatores contribuem para o efeito de borda, como ventos, luminosidade, fogo, invasão de animais domésticos e plantas diversas. Eles podem tornar o ambiente no entorno imediato do fragmento inóspito para as espécies e populações que nele habitam e, ao mesmo tempo, favorecer o estabelecimento de espécies de áreas abertas nas bordas do fragmento (SCARIOT, 2003, p.105).

Os efeitos da fragmentação do hábitat de florestas tropicais úmidas vem sendo estudados desde 1979 na floresta amazônica, no Projeto Dinâmica Biológica de Fragmentos Florestais. O monitoramento de espécies e comunidades selecionadas, antes e depois dos desmatamentos (para formação de pastagens), motivou centenas de teses e artigos que revelam, entre outras coisas, que a biodiversidade diminui mais rapidamente nas áreas menores (GANEM, DRUMMOND, 2011, p.29).

O desmatamento e a fragmentação de hábitats podem ser tidos como as maiores ameaças à biodiversidade, mas é importante considerar os efeitos sinérgicos de outros fatores. Populações reduzidas pela perda de hábitats e limitadas em pequenas manchas podem ter menor capacidade de adaptação às mudanças ambientais decorrentes da poluição e das alterações climáticas. A ação conjunta de todas as ameaças à biodiversidade descritas acima pode levar a homogeneização biótica, devido 
principalmente à constituição de paisagens dominadas por espécies com maior capacidade de adaptação aos impactos decorrentes das alterações humanas.

\section{2) Regime Jurídico}

\subsection{1) Convenção sobre Diversidade Biológica e Política Nacional sobre Biodiversidade}

A partir da criação da UNESCO, organismo da ONU fundado em 1946, foram realizadas várias reuniões internacionais que tinham como finalidade a discussão das questões ambientais, buscando-se, através do conhecimento científico e tecnológico dos sistemas naturais, o seu uso racional, podendo ser mencionadas como exemplos dessas reuniões a Conferência da Biosfera (1968) e a Conferência de Ramsar (1971) (LERNER, 2011, p.5).

O Programa das Nações Unidas para o Meio Ambiente - PNUMA, fundado em 1972 pela Assembleia Geral da ONU, faz jus ao destaque por sua participação nas principais reuniões internacionais realizadas a partir de 1980, dentre as quais a mais notável é a Conferência das Nações Unidas para o Meio Ambiente, em 1992, no Rio de Janeiro, Brasil. Como frutos da CNUMAD, assinados pelo Brasil, devemos fazer referência nomeadamente no tocante à conservação da biodiversidade, a Convenção sobre a Diversidade Biológica, a Declaração de Florestas e a Agenda XXI. No presente trabalhado tratar-se-á com mais vagar sobre a Convenção sobre a Diversidade Biológica (LERNER, 2011, p.5,6).

A Convenção sobre Diversidade Biológica (CDB), está em vigor no plano internacional desde 29 de dezembro 1993, tendo sido aprovada pelo Decreto Legislativo $\mathrm{n}^{\circ}$ 2, de 1994, e promulgada pelo Decreto nº 2.519, de 16 de março 1998 no Brasil.

Nos termos do art. $1^{\circ}$, seus objetivos são "a conservação da diversidade biológica, a utilização sustentável de seus componentes e a repartição justa e equitativa dos benefícios derivados da utilização dos recursos genéticos, mediante, inclusive, o acesso adequado aos recursos genéticos e a transferência adequada de tecnologias pertinentes". Tais objetivos são detalhados ao longo do texto da convenção, da qual se pode extrair que a gestão sustentável da biodiversidade é um todo complexo, abrangendo diversas áreas do Direito Ambiental - como gestão de áreas protegidas, de 
material genético e proteção da fauna - e fazendo uso de diversos instrumentos - como a apresentação de relatórios de identificação e monitoramento (GRANZIERA, 2011, p.150).

A CDB possui três objetivos gerais: a conservação da diversidade biológica; a utilização sustentável de seus componentes; e a repartição justa e equitativa dos benefícios derivados da utilização dos recursos genéticos. Em seu art. 6ª a CDB determina que as Partes contratantes devem: desenvolver estratégias, planos ou programas para a conservação e a utilização sustentável da diversidade biológica ou adaptar a esse fim as estratégias, planos ou programas que reflitam, entre outros aspectos, as medidas estabelecidas na Convenção, concernentes à Parte interessada; e integrar, na medida do possível e conforme o caso, a conservação e a utilização sustentável da diversidade biológica em planos, programas e políticas setoriais ou intersetoriais pertinentes.

Como a CDB adotou um modelo de Convenção - Quadro, sua operacionalização vem sendo feita paulatinamente, de acordo com as decisões tomadas pelos Estados signatários nas Conferências das Partes. Até o ano de 2012, foram realizadas onze conferências- sendo que a última ocorreu em outubro de 2012 em Hyderabad (Índia).

A primeira iniciativa brasileira no sentido de implementar o objetivo previsto no art. $6^{\circ}$ da $\mathrm{CDB}$, qual seja, o de estabelecer um plano nacional para a conservação e o uso sustentável da biodiversidade, foi a criação do Programa Nacional da Diversidade Biológica (PRONABIO) pelo Decreto $\mathrm{n}^{\circ}$ 1.354, de 29 de dezembro 1994. Posteriormente, o PRONABIO foi modificado pelo Decreto $\mathrm{n}^{\circ} 4.703$, de 21 de maio 2003 para adequar-se à Política Nacional da Biodiversidade, introduzida pelo Decreto $\mathrm{n}^{\mathbf{o}}$ 4.339, de 22 de agosto 2002. Além disso, revogou o decreto no 1.354 de 1994 e estabeleceu a Comissão Nacional da Biodiversidade (CONABIO).

A CONABIO é composta por representantes de órgãos governamentais e organizações da sociedade civil, e tem um relevante papel na discussão e implantação das políticas sobre a biodiversidade. Compete à comissão promover a implementação dos compromissos assumidos pelo Brasil junto à $\mathrm{CDB}$, bem como identificar e propor áreas e ações prioritárias para pesquisa, conservação e uso sustentável dos componentes da biodiversidade.

O Decreto nº 4.339 de 2002 foi editado em complementação à CDB. Instituiu 
princípios e diretrizes para a implementação da Política Nacional da Biodiversidade, considerando os compromissos assumidos pelo Brasil ao assinar a Convenção sobre Diversidade Biológica. Dispôs que o desenvolvimento de estratégias, políticas, planos e programas nacionais de biodiversidade é um dos principais compromissos assumidos pelos países-membros da Convenção sobre Diversidade Biológica.

A Política Nacional da Biodiversidade tem como objetivo geral a promoção, de forma integrada, da conservação da biodiversidade e da utilização sustentável de seus componentes, com a repartição justa e equitativa dos benefícios derivados da utilização dos recursos genéticos, de componentes do patrimônio genético e dos conhecimentos tradicionais associados a esses recursos. ${ }^{4}$

Aludida política é formada por cinco elementos, e respectivos objetivos específicos, sendo que tais elementos devem ser apreciados como eixos temáticos que nortearão as etapas de desenvolvimento desta política. São esses componentes (i) o conhecimento da biodiversidade, (ii) a conservação da biodiversidade, (iii) utilização sustentável dos componentes da biodiversidade, (iv) monitoramento, avaliação, prevenção e mitigação de impactos sobre a biodiversidade e (v) acesso aos recursos genéticos e aos conhecimentos tradicionais associados e repartição de benefícios.

A Política Nacional de Biodiversidade é dotada de princípios, diretrizes, objetivos e componentes. Embora para alguns autores estes elementos constituam um conjunto assistemático de declarações que não harmonizaram a matéria ${ }^{5}$, observa-se, que a iniciativa constituiu um passo importante no sentido de sistematizar e desenhar a Política Nacional de Biodiversidade, mesmo contanto com algumas imperfeições e confusões na delimitação e definição destes elementos.

Segundo o Ministério do Meio Ambiente ${ }^{6}$ a elaboração da proposta da Política Nacional de Biodiversidade fez parte de um processo concebido para ter seu desenvolvimento em cinco etapas que se complementam: (1) levantamento e divulgação de informações básicas relacionadas à diversidade biológica; (2) consolidação de informação, e identificação de ações prioritárias de conservação para os cinco grandes biomas do país; (3) realização de ampla consulta nacional sobre as preferências e prioridades para conservação, utilização sustentável e repartição de benefícios derivados

\footnotetext{
${ }^{4}$ Decreto ${ }^{\circ} 4.339 / 02$, item 5 do Anexo.

5 ANTUNES. Paulo de Bessa. Direito Ambiental. 14 ed.- São Paulo: Atlas, 2012. p.543

${ }^{6}$ Política Nacional de Biodiversidade: roteiro de consulta para elaboração de uma proposta.

Brasília: MMA/SBF, 2000. 48p. (Biodiversidade, 1).p.9.
} 
do uso dos recursos naturais, expressos sob a forma de diretrizes, objetivos e metas, a serem aplicados nacionalmente; (4) elaboração da proposta de política nacional de biodiversidade; e (5) encaminhamento da proposta para apreciação e endosso político.

A proposta da Política Nacional de Biodiversidade, segundo o documento citado cima, teria sido elaborada a partir de consultas promovidas pelos governos das unidades da federação, lideranças da sociedade civil e do setor empresarial. Os resultados dessas consultas apresentados e consolidados em quatro reuniões regionais coordenadas pelo Ministério do Meio Ambiente. A realização de consultas estaduais foi responsabilidade de cada estado, a partir de um roteiro sugerido pelo Ministério do Meio Ambiente, com informações sobre os procedimentos para efetuar o processo. Ao final do processo, a versão final da Política Nacional de Biodiversidade foi convertida em um instrumento legal, que normatiza a gestão da biodiversidade no Brasil.

Neste sentido, a participação dos representantes dos setores gestores da biodiversidade teria alterado de forma significativa a estrutura e o conteúdo da Política Nacional da Biodiversidade. Ao construir uma Política Nacional da Biodiversidade com esta metodologia de participação, o Ministério do Meio Ambiente teria a intenção de dar voz àqueles diretamente afetados pela Política, para que ela refletisse, no maior grau possível, todas as suas demandas ${ }^{7}$.

Apesar de não se ter encontrado trabalhos que analisassem se o processo de formulação da Política foi realmente democrático propiciando ampla participação e acesso à informação, o que se verifica é que no plano teórico a metodologia foi construída para tanto.

No que tange a implementação e o alcance de metas relacionadas à biodiversidade cumpre salientar que estas estão intimamente ligadas ao cumprimento dos compromissos assumidos pelo Brasil no âmbito da CDB.

Como se sabe, metas são mecanismos para avaliação de um acordo, neste caso também podem ser utilizadas para avaliar a Política Nacional de Biodiversidade. No caso da CDB, um conjunto de metas globais foi estabelecido para o período 2002-2010, foi criado também um plano estratégico para direcionar a implementação da Convenção em nível nacional, regional com a finalidade de interromper a perda da biodiversidade e garantir a assiduidade de seus benefícios e sua distribuição justa. Infelizmente, os balanços assinalam que o Plano Estratégico 2002-2010 não foi efetivo.

\footnotetext{
${ }^{7}$ Informações disponíveis em : http://www.mma.gov.br/estruturas/chm/_arquivos/2relat_cap2.pdf
} 
De acordo com o Panorama da Biodiversidade Global:

\begin{abstract}
A meta acordada pelos governos do mundo em 2002 é "atingir até 2010 uma redução significativa da taxa atual de perda de biodiversidade em níveis global, regional e nacional como uma contribuição para a diminuição da pobreza e para o benefício de toda a vida na Terra" não foi alcançada (Secretariado da Convenção sobre Diversidade Biológica, 2010a, p. 8).
\end{abstract}

Já no Brasil, segundo dados do Ministério do Meio Ambiente foram definidas, em 2006, 51 metas nacionais de biodiversidade para 2010 relacionadas às metas globais da $\mathrm{CDB}$, algumas das quais mais ambiciosas que aquelas da Convenção. As metas nacionais foram aprovadas pela Comissão Nacional de Biodiversidade (CONABIO) em 2006, e publicadas por meio da Resolução CONABIO n 3 . No geral, o alcance das metas brasileiras também teve problemas, apesar de ter havido avanços muito significativos, como o aumento da área sob proteção de unidades de conservação e a queda do desmatamento. Das 51 metas nacionais para 2010, pelo menos 34 (67\%) tiveram $25 \%$ ou menos de êxito. Duas metas foram totalmente alcançadas: redução de $25 \%$ dos focos de calor e disponibilização de listas de espécies em bancos de dados permanentes. ${ }^{8}$

Neste ínterim, faz-se necessário relembrar que apesar de o mundo ter fracassado no alcance da meta principal, a ação global resultou em uma menor perda da biodiversidade do que ocorreria na sua ausência. A política pública se desenvolve em ciclos dinâmicos, e não fases estanques, por isso avaliar pontos positivos e negativos e melhorar as estratégias de conservação, mesmo que se constate a ineficiência de algumas ações tornam o processo mais rico e hábil para alcançar os fins almejados. Por este motivo reunidas em Nagoya, no Japão, durante a $10^{\mathrm{a}}$ Convenção das Partes da $\mathrm{CDB}$, as partes concordaram em trabalhar juntas para implementar 20 novas metas até 2020, inclusive com submetas para datas intermediárias e avaliações ao longo do caminho, para que o alcance das mesmas se torne mais factível.

O Brasil teve uma função relevante na definição das Metas de Aichi, assim é importante que, ao se debater e planejar novas metas nacionais para 2020, a experiência

\footnotetext{
${ }^{8}$ UICN, WWF-BRASIL e IPÊ. Metas de Aichi: Situação atual no Brasil. Ronaldo Weigand Jr; Danielle Calandino da Silva; Daniela de Oliveira e Silva. Brasília, DF: UICN, WWF-Brasi e IPẾ, 2011.
} 
frustrada das metas de 2010 seja aferida e metas realistas sejam recomendadas, até mesmo com submetas para datas intermediárias e avaliações ao longo do caminho.

As 20 metas adotadas no Plano Estratégico para Biodiversidade para o período 2011 a 2020 abarcam um conjunto vasto de metas que envolvem todos os setores da sociedade, aliadas em cinco objetivos estratégicos: tratar das causas subjacentes da perda da biodiversidade por meio da transversalização da biodiversidade no governo e na sociedade (4 metas); reduzir as pressões diretas sobre a biodiversidade e promover seu uso sustentável (6 metas); melhorar o estado da biodiversidade com a salvaguarda dos ecossistemas, das espécies e da diversidade genética (3 metas); ampliar os benefícios para todos da biodiversidade e dos serviços ecossistêmicos (3 metas); melhorar a implementação por meio de planejamento participativo, gestão do conhecimento e capacitação (4 metas). ${ }^{9}$

Cabe ressaltar que como um dos maiores desafios para a implementação das metas e construção de uma estratégia para conservação da biodiversidade, tem-se a situação atual do Brasil em relação às metas, o ideal seria que tivéssemos indicadores claramente definidos. Outro desafio para a verificação é que as metas de 2020 da CDB têm sua formulação expressando ora a implementação de atividades e estratégias, ora o alcance de resultados e impactos, ora o alcance de certos resultados e impactos por meio de algumas atividades e estratégias. Pode ocorrer de as atividades e estratégias serem praticadas sem que os resultados sejam conseguidos, ou que os resultados sejam alcançados por meio de estratégias e atividades não listadas nas metas. Ademais, dentre as metas de 2020, existem metas que poderiam ser tidas como diretrizes, pois apontam a direção para uma ação global e não o ponto de chegada esperado para $2020^{10}$.

Além disso, algumas metas específicas são difíceis de serem verificadas em razão da ausência de dados sistematizados para a geração de indicadores da situação atual. Por exemplo, enquanto existe uma série histórica longa de desmatamento na Amazônia, nos demais biomas esses dados não estão disponíveis (ou estão começando a ser gerados de forma retroativa). Dados sobre a efetividade dos sistemas de áreas

\footnotetext{
${ }^{9}$ UICN, WWF-BRASIL e IPÊ. Metas de Aichi: Situação atual no Brasil. Ronaldo Weigand Jr; Danielle Calandino da Silva; Daniela de Oliveira e Silva. Brasília, DF: UICN, WWF-Brasi e IPÊ, 2011.

${ }^{10}{ }^{10}$ UICN, WWF-BRASIL e IPÊ. Metas de Aichi: Situação atual no Brasil. Ronaldo Weigand Jr; Danielle Calandino da Silva; Daniela de Oliveira e Silva. Brasília, DF: UICN, WWF-Brasi e IPÊ, 2011.
} 
protegidas estão começando a ser gerados, e ainda não cobrem todo o sistema nacional. $^{11}$

\subsection{2) Repartição de competências}

No caput do art. 225 da Constituição de 1988, o meio ambiente ecologicamente equilibrado é definido como um direito de todos, e impõe-se ao Poder Público e a coletividade o dever de defendê-lo e preservá-lo para as presentes e futuras gerações.

Nos incisos do artigo mencionado, é fixada uma série de atribuições para o Poder Público: preservar e restaurar os processos ecológicos das espécies e ecossistemas; preservar a diversidade e a integridade do patrimônio genético do país; definir espaços territoriais e seus componentes a serem especialmente protegidos; exigir estudo prévio de impacto ambiental para a instalação de obra ou atividade potencialmente degradadora; controlar a produção, a comercialização e o emprego de técnicas, métodos e substâncias que comportem risco para a vida, a qualidade de vida e o meio ambiente, e proteger a fauna e a flora.

No que tange à repartição de competências, o meio ambiente e, em especial, a conservação da biodiversidade estão fixados na Constituição entre as matérias sujeitas à competência material (administrativa) comum e a competência legislativa concorrente, artigos 23 e 24 respectivamente. Ou seja, a União, os estados e os municípios têm obrigações em termos de políticas públicas e de legislação atinentes à conservação da biodiversidade em condições de igualdade (competência administrativa) e em condições concorrentes (competência legislativa).

A competência em matéria ambiental pode ser dividida em quatro grandes temas: flora, fauna, acesso aos recursos genéticos e licenciamento ambiental de atividades impactantes, aos quais estão associados diversos subtemas, observa-se, contudo, que em razão do objeto deste trabalho tratar-se-á de maneira específica apenas do primeiro tema.

A análise das sete constituições pátrias quanto à conservação da biodiversidade

\footnotetext{
${ }^{11}$ UICN, WWF-BRASIL e IPÊ. Metas de Aichi: Situação atual no Brasil. Ronaldo Weigand Jr; Danielle Calandino da Silva; Daniela de Oliveira e Silva. Brasília, DF: UICN, WWF-Brasi e IPÊ, 2011.
} 
demonstra que sua tutela jurídica ocorreu de forma direta apenas na versão atual (VIANA, 2004, p.07).

Nos anos de 1930, foram editadas leis ambientais relevantes: o primeiro Código Florestal e o Código de Águas destaca-se também a criação dos primeiros parques nacionais, que foram as sementes para o Sistema Nacional de Unidades de Conservação (SNUC) criado após algumas décadas. Foi a Constituição de 1934 a primeira a prever a competência privativa da União para legislar sobre florestas, caça e pesca (art. $5^{\circ}$, inciso XIX, alínea "j") e a competência concorrente da União e dos estados para proteger as belezas naturais (art. 10, inciso III). A competência privativa para legislar sobre os temas assinalados acima não excluía a legislação estadual supletiva ou complementar sobre o mesmo tema (art. 5,$\S 3^{\circ}$ ) (VIANA, 2004, p.09).

A Constituição de 1937 manteve a competência privativa da União para legislar sobre águas, florestas, caça e pesca (art. 16, inciso XIV). Já a Constituição de 1946 manteve a competência da União para legislar sobre florestas, caça e pesca, mas não se fazia mais presente o caráter privativo dessa competência (art. $5^{\circ}$, inciso $\mathrm{XV}$, alínea $l$, c/c art. $6^{\circ}$ ), ao passo que na Constituição de 1967 estabeleceu-se a competência exclusiva da União para legislar sobre esses temas (art. $8^{\circ}$, inciso XVII, alíneas $h$ e $i$, c/c parágrafo único) (VIANA, 2004, p.10).

Em 1965, foi editado o novo Código Florestal, lei n 4.771 , de 15 de setembro de 1965, que centralizou a quase totalidade do controle da exploração florestal na esfera federal de governo. O Instituto Brasileiro de Desenvolvimento Florestal (IBDF), criado em 1967, viria a concentrar as principais responsabilidades nesse sentido, como órgão autárquico vinculado ao Ministério da Agricultura, com a finalidade de formular a política florestal, orientar, coordenar e executar ou fazer executar a implantação das medidas visando à utilização racional, a proteção e a conservação dos recursos renováveis. Como o texto do novo Código Florestal continha uma série de dispositivos que centralizavam atribuições administrativas na União, o IBDF passou a responder por praticamente todo o controle da questão florestal no país e também pela administração das áreas protegidas de domínio da União (VIANA, ARAÚJO, 2011, p.144).

A Secretaria Especial de Meio Ambiente (SEMA) foi instituída em 1973, vinculada ao Ministério do Interior. Apesar de ela se ter voltado mais para o controle da poluição e da degradação ambiental, detinha uma série de competências em duplicidade com o IBDF, como a assessoria para o uso racional dos recursos naturais e a cooperação com os órgãos especializados na preservação de espécies da fauna e da flora ameaçadas 
de extinção, bem como na manutenção de estoques de material. Além disso, havia alguma competição entre a SEMA e o IBDF, o que, por vezes, gerava acordos de certa forma estranhos, como o de que, no que toca as unidades de conservação (UC), a Sema cuidaria das estações ecológicas, e o IBDF, dos parques nacionais (FRANCO, 2000) VIANA, ARAÚJO, 2011, p.143).

Uma tentativa admirável de descentralização e coordenação das atividades dos órgãos ambientais veio no início da década de 1980, com a criação do Sistema Nacional do Meio Ambiente (SISNAMA) pela Lei da Política Nacional do Meio Ambiente, Lei $n^{\circ}$ 6.938, de 31 de agosto de 1981. A SEMA avocou, então, o papel de órgão central do novo sistema criado. Com a vinda da Carta Política de 1988, formalizou-se a orientação descentralizadora que está subjacente ao SISNAMA, procurando-se consolidar um tratamento mais integrado e consistente a questão ambiental e a conservação da biodiversidade (VIANA, ARAÚJO, 2011, p.144).

Acompanhando a estruturação em nível mundial do moderno ambientalismo, entre 1970 e 1980, acentuou-se a participação da sociedade civil nos debates sobre a questão ambiental no país, com o surgimento de várias organizações não governamentais (ONG) ambientalistas. Nessa linha, a criação do Conselho Nacional do Meio Ambiente (CONAMA), pela mesma lei que instituiu o SISNAMA, pode ser entendida como resposta a demanda por decisões pelo menos em parte compartilhadas com a sociedade civil VIANA, ARAÚJO, 2011, p.144).

Como inovação no plano organizacional, foi criado, em 1985, o Ministério do Desenvolvimento Urbano e Meio Ambiente (MDU) e, em 1990, a Secretaria de Meio Ambiente da Presidência da República (SEMAM/PR), depois Ministério do Meio Ambiente (1992), futuros Ministério do Meio Ambiente e da Amazônia Legal (1993), Ministério do Meio Ambiente, dos Recursos Hídricos e da Amazônia Legal (1994 1995) e, por fim, o atual Ministério do Meio Ambiente (MMA), com tal denominação desde 1999 (VIANA, ARAÚJO, 2011, p.145).

Em 1989, foi criado o Instituto Brasileiro do Meio Ambiente e dos Recursos Naturais Renováveis (IBAMA), reunindo as atribuições do IBDF e da SEMA. A autarquia assumiu de início as funções de órgão central do SISNAMA e, logo depois, de órgão executor (no plano federal).

Não obstante a intenção congregadora, o IBAMA, de certa forma, manteve em seu corpo duas lógicas distintas: centralização das atividades de gestão e controle florestal, reguladas pelo Código Florestal e herdadas do IBDF, e atuação apenas 
supletiva nas atividades de controle da poluição e outras formas de degradação ambiental, reguladas pela Lei da Política Nacional do Meio Ambiente e herdadas da SEMA(VIANA, ARAÚJO, 2011, p.144).

Contudo, a tendência de centralizar atribuições ambientais executivas em uma única entidade começou a ser inversa já na segunda metade da década de 1990. Permaneceram no MMA e no IBAMA apenas as responsabilidades relacionadas a política de preservação, conservação e uso sustentável dos recursos naturais (VIANA, ARAÚJO, 2011, p.144).

No que tange aos recursos florestais, em 2006 foi constituído, pela Lei $\mathrm{n}^{\circ}$ 11.284, o Serviço Florestal Brasileiro (SBF), com a incumbência de harmonizar uso e conservação das florestas, através, basicamente, da gestão de florestas públicas de domínio da União. Sua instituição causou polêmica com os técnicos do IBAMA. Em 2007, também em meio a polêmicas, a entidade teve outra parte de suas atribuições transferidas para o Instituto Chico Mendes de Conservação da Biodiversidade (ICMBio), criado pela Lei no 11.516, de 28 de agosto de 2007. A nova autarquia compete, sobretudo, as ações relacionadas à gestão do Sistema Nacional de Unidades de Conservação da Natureza (VIANA, ARAÚJO, 2011, p.145).

Portanto, depois de sua criação, em 1989, nota-se um segundo esvaziamento da competência do IBAMA ao longo dos últimos tempos. As várias "idas e vindas" na análise da questão ambiental geram efeitos na conservação da biodiversidade no domínio federal, mas não se restringindo nele: a condição nos estados é semelhante, no Distrito Federal e nos municípios, em que o meio ambiente é tratado ora em órgão específico, ora em conjunto com outros temas (ciência e tecnologia, infraestrutura, turismo, agricultura, desenvolvimento econômico etc.). Isso decorre, especialmente, da disputa interminável acerca do tipo de tratamento organizacional mais adequado a incorporação da variável ambiental nas políticas públicas, qual seja a constituição de um ente específico ou a transversalização do tema nas demais estruturas governamentais VIANA, ARAÚJO, 2011, p.146).

Conforme já referido, e seguindo a lógica do federalismo cooperativo, o meio ambiente e, em especial, a conservação da biodiversidade, em nossa atual Carta Política, estão inseridos entre as matérias sujeitas à competência material comum e a competência legislativa concorrente. O parágrafo único do art. 23 , com redação dada pela Emenda Constitucional no 53 de 2006, estatui que "leis complementares fixarão 
normas para a cooperação entre a União e os estados, o Distrito Federal e os municípios, tem em vista o equilíbrio do desenvolvimento e do bem-estar em âmbito nacional”.

Em obediência ao disposto acima foi editada em 08 de dezembro de 2011 a lei complementar 140 que repartiu as competências administrativas entre a União, os estados e os municípios.

No que concerne à conservação da biodiversidade em matéria florestal ficou definido que à União cabe: promover o licenciamento ambiental de empreendimentos e atividades localizados ou desenvolvidos em unidades de conservação instituídas pela União, exceto em Áreas de Proteção Ambiental (APAs); aprovar o manejo e a supressão de vegetação, de florestas e formações sucessoras em: (i) florestas públicas federais, terras devolutas federais ou unidades de conservação instituídas pela União, exceto em APAs, e (ii) atividades ou empreendimentos licenciados ou autorizados, ambientalmente, pela União; elaborar a relação de espécies da flora ameaçadas de extinção; controlar a introdução no País de espécies exóticas potencialmente invasoras que possam ameaçar os ecossistemas, habitas e espécies nativas; aprovar a liberação de exemplares de espécie exótica da flora em ecossistemas naturais frágeis ou protegidos.

Já as competências estaduais arroladas pela lei são as seguintes: promover o licenciamento ambiental de empreendimentos e atividades localizados ou desenvolvidos em unidades de conservação instituídas pelo estado, exceto em Áreas de Proteção Ambiental (APAs); aprovar o manejo e a supressão de vegetação, de florestas e formações sucessoras em: (i) florestas públicas estaduais, conservação instituídas pelo estado, exceto em APAs, (ii) imóveis rurais, obervadas as atribuições previstas no inciso $\mathrm{XV}$ do art. $7^{\circ}$ e (iii) atividades ou empreendimentos licenciados ou autorizados, ambientalmente, pela estado; elaborar a relação de espécies da flora ameaçadas de extinção no respectivo território.

Aos municípios, observadas as atribuições dos demais entes federativos cabe: promover o licenciamento ambiental de empreendimentos e atividades localizados ou desenvolvidos em unidades de conservação instituídas pelo município, exceto em Áreas de Proteção Ambiental (APAs); aprovar o manejo e a supressão de vegetação, de florestas e formações sucessoras em: (i) florestas públicas municipais, unidades de conservação instituídas pelo município, exceto em APAs, e a supressão e manejo de vegetação, florestas e formações sucessoras em empreendimentos licenciados ou autorizados, ambientalmente, pelo município. 
Por fim, observa-se que licenciamento ambiental de atividades ou empreendimentos localizados em APAs passou a ter regramento próprio, não se aplicando o critério do ente federativo instituidor da unidade de conservação para a definição de competência. A competência do ente que irá proceder ao licenciamento ambiental em área de Área de Proteção Ambiental (APA) será definida, em regra, pelo grau de impacto da atividade, independentemente se a APA é federal, estadual ou municipal.

Isto posto, pode-se inferir que as atribuições relacionadas à biodiversidade passaram por vários órgãos e autarquias, ora centralizadas ora descentralizadas. Estas modificações geraram incertezas e dúvidas dificultando a aplicação da legislação e a conservação da biodiversidade propriamente dita.

Embora, a Lei Complementar 140 de 2011, tenha como fito distribuir as competências principalmente relacionadas ao licenciamento, o que se verifica é que a mesma não possuiu a clareza necessária para tanto, sem que se gerem ao mesmo tempo dúvidas. 


\section{2) Espaços territoriais especialmente protegidos}

A Constituição de 1988 incumbiu ao Poder Público o estabelecimento em todas as unidades da federação de espaços territoriais e de componentes a serem especialmente protegidos, que somente poderão ser alterados ou suprimidos mediante lei. Vedou-se ainda qualquer forma de utilização que possa comprometer a integridade dos atributos que justificam proteção dos mesmos (art.225, $\S 1^{\circ}$, III).

A opção do legislador constituinte de utilizar no artigo supra a expressão "espaço territorial especialmente protegido" por vezes gera dificuldades de aplicação da norma constitucional já que o referido conceito não é consensual no meio técnico.

Em que pese as divergências conceituais e suas implicações quanto à extinção e modificação destes espaços, seguir-se-á neste trabalho com grande parte da doutrina que entende que os espaços territoriais a que se refere à Constituição não se restringem às unidades de conservação, abrangendo outros espaços sujeitos a limitações ambientais como as áreas de preservação permanente e a reserva legal.

Nas palavras de Silva (2010, p.233), "nem todo espaço territorial especialmente protegido se confunde com unidades de conservação, mas estas são também espaços especialmente protegidos".

Leme Machado (2005, p.135) sustenta que "a Constituição inova profundamente na proteção dos espaços territoriais, como unidades de conservação, áreas de preservação permanente e reservas legais florestais”.

Granziera (2011, p.445) vai além ao afirmar que os espaços protegidos pelo Direito brasileiro estão previstos em vários diplomas legais e regimes jurídicos distintos: na Constituição Federal, no Código Florestal que trata das áreas de preservação permanente e das áreas de reserva legal, na lei que dispõe sobre os sistema nacional de unidades de conservação e as reservas de bioesfera, na lei que trata da Mata Atlântica entre outros.

De acordo com Ferreira (2007, p.239) “em seu sentido ecológico pode-se afirmar que a expressão espaços territoriais e seus componentes remete à concepção de ecossistema".

Adotar-se-á, pois, o conceito de José Afonso da Silva para quem os espaços territoriais especialmente protegidos são áreas geográficas públicas ou privadas dotadas de atributos ambientais que requeiram sua sujeição, pela lei, a um regime jurídico que implique sua relativa imodificabilidade e sua utilização sustentada, tendo em vista a 
preservação e a proteção da integridade de amostras de toda a diversidade de ecossistemas, a proteção aos processos evolutivos das espécies, a preservação e a proteção dos recursos naturais (SILVA, 2009, p.233).

Extrai-se do conceito acima características comuns para os espaços especialmente protegidos quais sejam: necessidade de proteção especial para essas áreas, imposição de restrições, e a finalidade de proteção ambiental.

A criação dos espaços especialmente protegidos tem como finalidade precípua proteger a biodiversidade e os serviços ecossistêmicos. Vários são os fatores que podem ensejar a criação destes espaços, características físicas ou bióticas que tornem uma área relevante do ponto de vista ambiental, áreas frágeis, presença de espécies em extinção, manutenção da cobertura vegetal, beleza cênica entre outros.

No Brasil, não só as unidades de conservação são importantes para a proteção dos ecossistemas, as áreas de preservação permanente (APPs) e as reservas legais (RLs) conjuntamente com os demais espaços especialmente protegidos também desempenham um papel importante.

O Plano Nacional de Áreas Protegidas, decreto no 5.758, de 13 de abril de 2006, além de reconhecer as áreas protegidas como um instrumento eficaz para a conservação da diversidade biológica e sociocultural elenca como princípios a valorização da importância e da complementariedade de todas as categorias de unidades de conservação e demais áreas protegidas na conservação da diversidade biológica e sociocultural e o reconhecimento dos elementos integradores da paisagem, em especial as áreas de preservação permanente e as reservas legais, como fundamentais na conservação da biodiversidade (art.1.1, VII, VIII e XI).

Observa-se que criação de espaços especialmente protegidos significa delimitar a ação humana, vez que a norma traça a priori como o homem deve ocupar determinados espaços territoriais priorizando em determinadas situações a conservação ambiental e a garantia da qualidade de vida das futuras gerações. Faz-se necessário destacar que quando estas limitações "incidem sobre a propriedade privada elas constituem uma limitação administrativa ao exercício de propriedade, ancorada no princípio da supremacia do direito público sobre o particular e na função social da propriedade" (GRANZIERA, 2011, p.443). O artigo 186 da Constituição de 1988 coloca que a função social é respeitada quando a propriedade rural acata aos requisitos nele referidos, especialmente quanto à utilização adequada dos recursos naturais disponíveis e a preservação do meio ambiente e o Estatuto da Cidade destaca como 
diretriz a proteção, preservação e recuperação do meio ambiente natural e construído para que a propriedade urbana cumpra sua função social, lei no 10.257 de 2001, art.2 ${ }^{\circ}$, XII (GRANZIEIRA, 2011, p.443,444).

A robustez e a natureza das limitações estão sujeitas ao regime jurídico e a proteção estabelecida para cada espaço, nos próximos subcapítulos tratar-se-á do histórico, regime jurídico, fragilidades e perspectivas de três espaços especialmente protegidos: unidades de conservação, áreas de preservação permanente e reserva legal. Estes espaços foram escolhidos em razão do seu alcance, já que medidas universais, de sua importância histórica e por serem instrumentos chaves na conservação da biodiversidade. Observa-se que as Reservas de Biosfera, outro importante espaço especialmente protegido será objeto do capítulo seguinte.

\section{1) Unidades de Conservação}

\subsection{1) Histórico}

De acordo com a tradição, as políticas voltadas para a conservação repousam na criação de unidades de conservação (UCs). Segundo a Lei $n^{\circ}$ 9.985, de 18 de julho de 2000, que institui o Sistema Nacional de Unidades de Conservação da Natureza no Brasil (Lei do SNUC), as UCs são os espaços territoriais com características naturais relevantes e limites definidos, instituídos pelo Poder Público, sob regime especial de administração, com vistas a proteção da natureza em diferentes níveis, desde a preservação ao uso sustentável e a restauração e recuperação de ecossistemas degradados.

Quando se pensa na criação das unidades de conservação frequentemente se associa ao estabelecimento Parque Nacional de Yellowstone, criado em 1872 por Theodore Roosevelt, mas alguns autores vão além e afirmam que as unidades de conservação não são uma prática recentemente inventada (DOUROJEANNI; PÁDUA, 2007, p.53).

Já na pré - história, os mesmos povos que contribuíram para a aniquilação de vários mamíferos foram os primeiros a manejar, com o estabelecimento de campos de caça e de reservas naturais, onde a fauna podia se regenerar e eram caçados apenas os animais excedentes, que saiam das reservas. Já no ano 252 a.C o imperador Ashoka, da 
Índia, havia proibido a caça, a pesca e o corte de árvores em uma extensa região do seu território. O rei Guilherme I, da Inglaterra fez por sua vez no ano 1084 o que pode ser considerado o primeiro inventário nacional de terras, florestas, áreas de pesca, áreas agricultáveis e reservas de caça, entre outros recursos naturais produtivos do país para planejar o seu uso. As antigas culturas da costa do Peru protegiam as ilhas guaneras com medidas severas que incluíam a mutilação a morte dos infratores. No Pacífico os nativos maoris exigiram do governo da Nova Zelândia a criação do Parque Nacional do Tongariro( 1894) para proteger seus lugares sagrados contra madeireiros e criadores de ovelhas. Por fim, os asantes de Gana estabeleceram reservas absolutas em territórios sagrados que são respeitados até hoje (DOUROJEANNI; PÁDUA, 2007, p.53, 54).

Nota-se, pois, com esta pequena digressão histórica que os povos dos diversos continentes mesmo utilizando-se de técnicas e finalidades diversas asseguraram o respeito pelas reservas naturais, estabelecendo, tabus, mitos e até florestas sagradas.

Depois de Yellowstone, vários países começaram a criar seus parques nacionais como o Canadá em 1885, a África do Sul e a Austrália em 1898, a Argentina em 1903 e o Chile em 1926, entre outros. A primeira proposta de criação de parques nacionais no Brasil é de 1876 e foi feita por André Rebouças segundo o modelo norte- americano, mas somente em 1937 foi criado o Parque Nacional de Itatiaia (BENSUSAN, 2006, p.14).

Embora em 1933 ainda não houvesse uma definição mundialmente aceita sobre os objetivos dos parques nacionais, foi realizada em Londres uma Convenção para a Preservação da Flora e da Fauna. Nesta ocasião definiu-se três características para os parques nacionais: áreas controladas pelo poder público, áreas para a preservação da flora e da fauna, objeto de interesse estético, geológico, onde a caça é proibida e áreas de visitação pública. No ano de 1959 a Organização das Nações Unidas divulgou a primeira lista de parques nacionais e reservas equivalentes e em 1960 foi criado dentro da União Nacional para a Conservação da Natureza (IUCN) a Comissão de Parques Nacionais e Áreas Protegidas com a finalidade de promover, monitorar e orientar o manejo dos espaços (BENSUSAN, 2006, p.15).

No $3^{\circ}$ Congresso Mundial de Parques, em Bali, começou-se a tratar a relação entre as populações locais e áreas protegidas, mas foi somente em 1985 que o debate sobre as populações em parques se ampliou. Ressalta-se que na $10^{\mathrm{a}}$ Assembleia Gerald da IUCN no ano de 1969 recomendou-se que a denominação de parques fosse utilizada 
somente para as áreas que tivessem as características acima delineadas (BENSUSAN, 2006, p.14).

O $4^{\circ}$ Congresso Mundial de Parques, realizado em Caracas no ano de 1992 sinalizou a mudança em relação às populações humanas e ás áreas protegidas, salientando o respeito às populações tradicionais, a rejeição da estratégia de reassentamento e a inserção destas populações nas áreas sempre que possível (BENSUSAN, 2006, p.18).

Por fim em 2003, foi firmado o acordo de Durban, que apesar de não possuir um mandato formal, sugere uma série de atividades internacionais, regionais, nacionais e locais. Nas áreas protegidas, o acordo estabelece ainda o compromisso de conservação da biodiversidade em dois pilares: áreas protegidas e populações humanas. (BENSUSAN, 2006, p.18).

No Brasil, o Código Florestal de 1934, Decreto n 23.793, introduz as unidades de conservação, subdividindo-as em três categorias: duas de natureza inalienável e conservação perene, as florestas protetoras, em domínios privados e as florestas remanescentes, em terras públicas e a terceira era a das florestas de rendimento. Os parques nacionais, estaduais e municipais estavam incluídos na segunda categoria, florestas remanescentes (BENSUSAN, 2006, p.17, 18).

A Seção de Parques Nacionais foi encarregada em 1944 de orientar, fiscalizar, coordenar e elaborar programas de trabalho para os parques nacionais. O Código Florestal de 1965 definiu o conceito de parques nacionais conciliando a proteção integral da flora, da fauna, das belezas naturais com a utilização para objetivos educacionais, recreativos e científicos. Em 1967 com a criação do Instituto Brasileiro de Desenvolvimento Florestal (IBDF), a administração das áreas protegidas passa a ficar a cargo deste instituto (BENSUSAN, 2006, p.17, 18).

Mas o planejamento do primeiro sistema de unidades de conservação foi efetuado somente no ano de 1979 pelo IBDF com o apoio da organização não governamental Fundação Brasileira para a Conservação da Natureza e denominava-se "Plano do Sistema de Unidades de Conservação do Brasil". À época o país possuía 18 Parques Nacionais e oito Reservas Biológicas. Em toda a Amazônia havia somente um Parque Nacional decretado. Nesse plano foram traçados os objetivos nacionais para as unidades de conservação quais sejam: a necessidade do estabelecimento de outras categorias de manejo, diversas das que já estavam nas legislações então em vigor: o Código Florestal (1965) e a Lei de Proteção à Fauna (1967), o estabelecimento de novas 
unidades de conservação, em especial na região da Amazônia, na Caatinga e costeiromarinha. Em 1982 foi sancionada pelo governo e publicada sua segunda etapa, ainda pelo IBDF e já com o seu nome atual (Sistema Nacional de Unidades de Conservação) e sua sigla atual (SNUC). A edição desta segunda etapa sinalizava para a necessidade de uma lei específica que amparasse o sistema, estabelecesse novas categorias de unidades e que clarificasse quais eram os objetivos gerais de conservação e os das categorias de manejo (PÁDUA, 2011, p. 22, 23).

Em face desta necessidade o IBDF e a SEMA, firmaram em julho de 1988 um protocolo de intenções com a organização não governamental Fundação Pró Natureza (FUNATURA), para que a esta elaborasse a revisão e atualização conceitual do conjunto de categorias de unidades de conservação, incluindo a elaboração de um Anteprojeto de Lei, para dar o suporte legal ao Sistema. Os recursos foram primeiramente repassados pelo IBDF, em 1988, e posteriormente pelo então recémcriado IBAMA (PÁDUA, 2011, p. 23).

A FUNATURA contou, na oportunidade, com a assessoria de vários especialistas da época. Como saldo do trabalho foi publicado em 1989 (Sistema Nacional de Unidades de Conservação- SNUC, Aspectos Conceituais e Legais) pelo IBAMA e FUNATURA, contendo duas versões de Anteprojetos de Lei para que o sistema tivesse, entre outras necessidades, a base legal suficiente. Estes Anteprojetos de Lei, prontos e publicados em 1989, resultaram, após uma longa e demorada discussão no Executivo e ainda com análise e aprovação de uma minuta pelo Legislativo, que realizou diversas consultas públicas, causando enormes modificações, na lei do SNUC, Lei 9.985 de 19 de julho de 2000 (PÁDUA, 2011, p. 23).

Maria Tereza Jorge de Pádua, que coordenava os especialistas que assessoraram a FUNATURA salienta, todavia que:

nas etapas finais, os especialistas que preparam o Anteprojeto perderam a sua influência, em beneficio de membros do poder legislativo e dos seus assessores, que representam os mais diversos interesses. Assim sendo, muitas das mudanças de última hora, que em vários artigos refletem tendências políticas partidárias e, em especial, muito desconhecimento do tema sobre o qual se legislou, fizeram sentir negativamente seu peso na aplicação da mesma (PÁDUA, 2011, p.24). 
De forma sintética, Bensunsan (2006, p.19) afirma que: a partir da base constitucional (art. 225 da CF 1988) o país arquitetou o Sistema Nacional de Unidades de Conservação (SNUC). O processo de elaboração deste sistema durou mais de 10 anos e gerou ampla polêmica entre os ambientalistas, o resultado foi uma tentativa de conciliação entre visões bem distintas que apesar de não agradar inteiramente a nenhuma das partes envolvidas na polêmica, significou um avanço importante na construção de um sistema efetivo de áreas protegidas no país.

\subsection{2) Regime Jurídico das Unidades de Conservação}

Como indicado pelo nome uma unidade de conservação é uma área dedicada à conservação da natureza. A expressão equivalente, área protegida, remete com a mesma clareza que seu objetivo é a proteção da natureza. Observa-se, contudo, que com o advento do conceito de desenvolvimento sustentável esta noção foi flexibilizada para incorporar outras dimensões, como a social (DOUROJEANNI; PÁDUA, 2007, p.56).

A Constituição Federal construiu um complexo relacionamento entre diferentes direitos individuais e o direito de proteção ao meio ambiente, principalmente quanto ao direito de propriedade privada, concedendo a este último um novo papel na proteção ambiental (ANTUNES, 2012, p.652).

A obrigação de defesa do meio ambiente e a função social da propriedade condicionam a forma de valoração dos bens ambientais para a finalidade de apropriação. Ante esta perspectiva qualquer relação de apropriação deve permitir o cumprimento de duas funções distintas: uma individual (dimensão econômica da propriedade), e uma coletiva (dimensão socioambiental da propriedade) (AYALA, 2007, p.265).

O regime geral de proteção desses espaços foi definido pelo art. $225, \S 1^{\circ}$, III, do texto constitucional, que definiu regras gerais para sua proteção e os dotou de especial relevância.

A criação de espaços protegidos é um dos instrumentos previstos pela lei $n^{\circ}$ 6.938 de 1981, a Constituição progrediu neste tema ao dispor que a somente a lei poderá suprimir a proteção ou alterar o regime jurídico dos espaços protegidos.

“As unidades de conservação são criadas por ato do poder público, ou seja, mediante lei-ato do Poder Legislativo- ou por decreto- ato do poder executivo- nas esferas federal, estadual ou municipal" (GRANZIERA, 2011, p.495). Alguns autores 
como José Afonso da Silva questionam a possibilidade de criação das unidades via decreto $^{12}$. $\mathrm{O}$ ato de criação de uma Unidade de Conservação deve basear em estudos técnicos e em consulta pública e devem prever a localização, a dimensão e os limites mais adequados para a unidade. Portanto, dois fatores são relevantes: um de cunho técnico e outro de natureza política (GRANZIERA, 2011, p. 495).

Os estudos técnicos ficam a cargo do órgão proponente, já que são o instrumento técnico de apoio às decisões políticas de criação das unidades. Referido estudo deve incluir a descrição da característica natural mais relevante que poderá fundamentar a denominação da mesma, a categoria a ser proposta, a caracterização do território com finalidade de definir a área e seus limites e informações conclusivas sobre as populações envolvidas no caso das Reservas Extrativistas, Desenvolvimento Sustentável e Florestas Nacionais, Estaduais e Municipais (GRANZIERA, 2011, p. 495, art. 22 da lei 9985/2000).

As consultas públicas são obrigatórias exceto para a criação de Estação Ecológica ou de Reserva Biológica. As consultas possuem fatores políticos, quais sejam: a possibilidade de participação da população envolvida no processo de criação da unidade e servir de base para a definição da localização e extensão da unidade (GRANZIERA, 2011, p.496).

Os objetivos e diretrizes definidos pela Lei do SNUC mostram que as quatro principais preocupações contempladas foram: (a) a conservação da biodiversidade em seus três níveis fundamentais (diversidade genética, de espécies e de ecossistemas), (b) o uso sustentável dos recursos naturais, (c) a participação da sociedade e (4) a distribuição equitativa dos benefícios auferidos por intermédio da criação, implementação e gestão das UCs. Esses pontos estão de acordo com os objetivos da CDB. Assim, além de ordenar as categorias criadas em diferentes épocas, por diferentes organismos governamentais e com diferentes objetivos, a Lei do SNUC reafirma e dá maior solidez à posição brasileira de adesão a CDB (DRUMMOND et. al., 2011, p. 349).

As unidades de conservação são divididas em dois grandes grupos: Unidades de Proteção Integral e Unidades de Uso Sustentável. O objetivo das Unidades de Proteção Integral é preservar a natureza, sendo admitido apenas o uso indireto dos seus recursos

\footnotetext{
${ }^{12}$ Para mais informações consultar: SILVA, José Afonso. Direito Ambiental Constitucional. São Paulo: Malheiros, 2010, p. 253, 254.
} 
naturais, com as exceções previstas na lei. O objetivo das Unidades de Uso Sustentável é compatibilizar a conservação da natureza com o uso sustentável de parcela de seus recursos naturais.

Na primeira modalidade se encontram a Estação Ecológica, a Reserva Biológica, o Parque Nacional, o Monumento Natural e o refúgio da Vida Silvestre, ao passo que dentro da segunda estão a Área de Proteção Ambiental, a Área de Relevante Interesse Ecológico, a Floresta Nacional, a Reserva Extrativista, a Reserva de Fauna, a Reserva de Desenvolvimento Sustentável e Reserva Particular de Patrimônio Natural.

Destaca-se que as categorias de manejo listadas acima se enquadram nos critérios definidos pela União Internacional para Conservação da Natureza (IUCN).

O número de categorias reconhecidas pela IUCN tem variado com o tempo, em um primeiro momento o número foi crescendo e posteriormente diminuindo até serem apenas seis: a i) reservas naturais estritas (áreas naturais manejadas principalmente com fins científicos); a ii) áreas silvestres (áreas naturais manejadas principalmente para proteção da natureza); b) parque nacional( áreas naturais manejadas principalmente para a proteção de ecossistemas e atividades recreativas); c) monumento natural (áreas protegidas manejadas para conservar características naturais específicas); d) área de manejo de habitats/ espécies ( áreas manejadas principalmente para conservação, com intervenção no nível de gestão); e) paisagens manejadas ( áreas terrestres ou marinhas, manejadas principalmente para conservar paisagens e recreação); e área protegida com recursos manejados (áreas de reserva de recursos manejados de forma sustentável) (DOUROJEANNI; PÁDUA, 2007, p.59).

A adequação das categorias do SNUC à classificação proposta pela IUCN permite ao sistema brasileiro adaptar-se aos padrões e as normas internacionais. Facilita a definição de estratégias para a captação de recursos, a realização de pesquisas, o intercâmbio de informações e experiências, o diálogo com agências internacionais e de outros países.

As modalidades se ligam aos objetivos e princípios do SNUC, algumas preveem a pesquisa científica, como a Estação Ecológica e a Reserva de Fauna. Outras permitem os usos econômicos sustentáveis, como na Floresta Nacional, na Reserva de Desenvolvimento Sustentável, na Reserva Extrativista e na Área de Preservação Ambiental.

Quanto à propriedade das terras as unidades podem ser públicas, mistas ou privadas. Nas unidades de conservação de domínio público o Poder Público é o responsável pela 
criação e manutenção da área. As áreas destas unidades de conservação caso privadas devem ser desapropriadas. As unidades que se enquadram neste regime são: Reserva Biológica, Estação Ecológica, Parque Nacional, Refúgio da Vida Silvestre, Floresta Nacional, Reserva Extrativista, Reserva de Fauna e Reserva de desenvolvimento Sustentável.

As de caráter misto aliam os dois regimes de propriedade, o público e o privado: São elas: Área de Proteção Ambiental (APA) e Área de Relevante Interesse Ecológico (ARIE). Nestas unidades há a possibilidade de convivência dos dois regimes, porém o poder público estabelece restrições ao uso da propriedade privada. Devem ser formados conselhos que administrem e disciplinem o uso e acesso aos recursos naturais. Por fim, existe aquela em que o domínio da área é exclusivamente particular é o caso das Reservas Particulares de Patrimônio Natural (RPPN).

Alguns autores aduzem que o enorme leque de categorias poderia ser bem reduzido, já que os objetivos de várias categorias são os mesmos que os de outras. Muitas dessas categorias de manejo têm objetivos bem similares, como as Reservas Biológicas com as Estações Ecológicas, as Reservas Extrativistas com as Reservas de Desenvolvimento Sustentável, as Áreas de Relevante Interesse Ecológico com os Refúgios de Vida Silvestre. Outras são de domínio privado, como as Áreas de Proteção Ambiental e as Reservas Particulares do Patrimônio Natural, embora estas últimas tenham caráter de perpetuidade (PÁDUA, 2011, p. 25).

A gestão das Unidades de Conservação fica a cargo dos órgãos e entidades do SNUC, mais precisamente dos entes federativos e de seus órgãos nos limites de suas competências. Os órgãos integrantes do SNUC são: a) órgão consultivo e deliberativo: o CONAMA, com atribuições de acompanhar a implementação do sistema; b) órgão central: Ministério do Meio Ambiente: com a finalidade de coordenar o sistema; c) órgãos executores: Instituto Chico Mendes de Conservação da Biodiversidade, órgãos estaduais e municipais, com a função de implementação do SNUC, subsidiar as propostas de criação e administrar as unidades de conservação, federal, estadual e municipais nas respectivas esferas de atuação (ANTUNES, 2012, p.663).

A Lei $n^{\circ} 9.985$ de 2000 dispõe sobre a necessidade dos Conselhos que podem ter caráter consultivo ou deliberativo, estas disposições relevam a importância da sociedade civil para a criação, manutenção e administração das unidades.

A função consultiva está adstrita aos pareceres, que podem ou não ser obedecidos pelo poder público, vez que não existe vinculação. As unidades de 
conservação de proteção integral devem ter obrigatoriamente um Conselho Consultivo, presidido pelo órgão ambiental responsável por sua administração e constituído por representantes de órgãos públicos, de organizações da sociedade civil, por proprietários das terras localizados em Refúgio da Vida Silvestre ou Monumento Natural, quando for o caso e por populações tradicionais residentes, enquanto não forem reassentadas (Lei $n^{\circ} 9.985 / 2000$, art. 29).

Já na função deliberativa, as decisões vinculam as atividades na unidades. Conselhos deliberativos estão previstos para as Reservas Extrativistas e Reservas de Desenvolvimento Sustentável. Para as demais categorias não há previsão legal específica de como o Conselho deverá ser constituído.

Por fim, salienta-se que as unidades de conservação por força de lei devem dispor de um Plano de Manejo, a ser elaborado com no máximo cinco anos após sua criação. O Plano de Manejo é um documento técnico mediante o qual se estabelecem de acordo com os objetivos gerais das unidades seu zoneamento e as normas que devem presidir o uso da área e o manejo dos recursos naturais, inclusive a implantação de estruturas físicas (Lei 9985 de 2000, arts. $2^{\circ}$ XVII, e 27) (SILVA, 2010, p. 258).

Ademais, o plano de manejo não deve ser limito à área da unidade de conservação. Já que deve considerar a zona de amortecimento e os corredores ecológicos, abarcando medidas que promovam sua integração à vida econômica e social das comunidades vizinhas (GRANZIERA, 2011, p. 505).

\subsection{3) Situação atual e perspectivas para as unidades de conservação}

Em termos quantitativos, segundo os dados do Cadastro Nacional de Unidades de Conservação (CNUC), mantido e gerenciado pelo Ministério do Meio Ambiente (MMA), as UCs criadas e administradas pelos governo federal e governos estaduais, somam 698 unidades, enquanto as Reservas Particulares do Patrimônio Natural (RPPNs) outras 973. Juntas, essas unidades estão distribuídas por todos os biomas do Brasil e recobrem aproximadamente $15 \%$ do território nacional (MEDEIROS; YONG 2011, p.11).

As informações referentes às unidades de conservação municipais, entretanto, ainda são muito dispersas e não representativamente inseridas no cadastro pelas prefeituras. Além disso, estima-se ainda que existam pelo menos mais 300 UCs 
estaduais ainda não oficialmente cadastradas no CNUC, com uma área total aproximada de 2 milhões de hectares (MEDEIROS; YONG, 2011, p. 12).

No estabelecimento e gestão das unidades de conservação, há algumas questões fundamentais que não podem deixar de ser consideradas e que ajudam a fornecer uma ideia das dimensões do desafio da conservação da biodiversidade.

Um primeiro aspecto refere-se à seleção de áreas para o estabelecimento das unidades, tema que é chave para a eficiência da conservação da biodiversidade. Muitas áreas foram criadas, sem muito conhecimento ou análise das condições ecológicas e sociais locais.

Em um primeiro momento, a escolha de áreas destinadas à conservação baseavase em critérios de "virgindade" (ambientes naturais, "selvagens", com uma idealizada ausência de interferência humana) e de beleza cênica. Este processo resultou numa distribuição tendenciosa de Unidades de Conservação em áreas remotas, em geral com altitudes mais elevadas, relevos acidentados e solos pobres, áreas onde a exploração econômica do território era mais dificultada ou menos rendosa caracterizado por uma representatividade desigual dos diferentes ecossistemas sub-amostrando ambientes economicamente mais "produtivos", como áreas mais planas e de solos férteis. (METZGER; CASSATI, 2006, p.3).

Ambientes nestas regiões são os mais ameaçados, e vêm sendo sistematicamente degradados, fragmentados ou simplesmente eliminados, apesar de serem ambientes de grande diversidade. Para evitar esse viés, é necessário o estabelecimento de critérios mais objetivos para a escolha de áreas para conservação. Foi apenas mais recentemente que a escolha de reservas passou a ser feita de forma a incorporar critérios biológicos, como a representatividade da ampla gama de atributos relacionados à biodiversidade, ou a manutenção da integridade biológica (METZGER; CASSATI, 2006, p.3).

Diante destes novos objetivos, e em função das limitações financeiras para a conservação, esse processo de escolha tem que ser otimizado. Vários procedimentos sistematizados, baseados em conceitos de representatividade e persistência, têm sido propostos com esta finalidade (Shafer 1999, Soulé \& Terborgh 1999, Margules \& Pressey 2000, Gaston et al. 2001, Groves et al. 2002). Todas as espécies, comunidades e ecossistemas teriam que estar, idealmente, representadas nas reservas de uma maneira que haja garantia da persistência desta representatividade ao longo do tempo. Essa persistência dependerá do afastamento dos fatores de ameaça, e de características intrínsecas do sistema (extensão da reserva, tamanho da população, conservação dos 
processos ecológicos mantenedores ou geradores da diversidade) (METZGER; CASSATI, 2006, p.4).

Esses procedimentos sistematizados para o planejamento da conservação incluem, em linhas gerais, as seguintes etapas: seleção de representantes/indicadores da biodiversidade; definição de metas ou objetivos para a conservação; avaliação das reservas existentes; seleção de novas áreas prioritárias; implementação, viabilização e manejo da rede de reservas. Embora este método seja eficiente na proteção da biodiversidade em relação à seleção $a d$ hoc de reservas, a sua aplicação depende da existência, em todas as áreas a serem analisadas, de dados biológicos ou de seus indicadores, obtidos de forma padronizada. A ausência de informação adequada pode limitar substancialmente sua aplicação. Este pode ser, em particular, o caso em regiões tropicais onde a biodiversidade é elevada, e muitas vezes pouco conhecida como no caso do Brasil. (METZGER; CASSATI, 2006, p. 4, 5).

Segue-se a este desafio a ausência de informação e a dificuldade de se lidar com a questão fundiária, que é parte importante para a gestão exitosa da unidade. No Brasil como se sabe, é grande a ausência de títulos de propriedade e em algumas regiões a existência de vários títulos para uma mesma propriedade. Há por fim, o apossamento tradicional de diversas populações como seringueiros, remanescentes de quilombos, castanheiros, ribeirinhos entre outros, que devem ser respeitados e integrados às políticas de desenvolvimento sustentável.

No que tange a gestão e consolidação de áreas protegidas, muitas áreas embora formalmente constituídas, não são na prática estabelecidas. Idealmente, estas deveriam possuir desde a sua criação, um orçamento adequado, recursos humanos capacitados, bases institucionais sólidas, apoio da sociedade e independência do cenário político.

Os números apresentados pelo Ministério do Meio Ambiente e pelo ICMBio mostram que, ao longo da última década, houve um incremento significativo no número de unidades de conservação e, mais importante, na área total protegida pelo sistema, que dobrou no período entre 2003 e 2010. Contudo, tal crescimento não foi acompanhado pelo aumento em igual proporção dos recursos destinados à gestão dessas áreas, o que dificulta de sobremaneira o alcance dos objetivos das unidades e do sistema como um todo (RANIERE, et. al., 2011, p. 154).

Poucas são as unidades que possuem recursos suficientes, por conseguinte, as unidades, mesmo as implantadas, enfrentam vários problemas de gestão. A maior parte dos problemas enfrentados pelo SNUC tem a mesma causa em comum: recursos 
insuficientes para sua implementação e manutenção, incluindo a criação de novas áreas que deveriam entrar no sistema nos próximos anos. Os recursos alocados, infelizmente, são insuficientes e não vêm acompanhando a expansão do sistema. Segundo o MMA, o orçamento federal para as unidades de conservação é praticamente o mesmo desde o ano 2000 (cerca de R \$300 milhões/ano), observando um aumento apenas 6,83\% entre os anos de 2000 e 2008, enquanto no mesmo período a área somada das UCs federais teve uma expansão de $78,46 \%$. Somadas todas as fontes de recursos disponíveis, o orçamento federal para as unidades de conservação atingiu $\mathrm{R} \$ 331$ milhões em 2008, um valor muito abaixo das necessidades mínimas. De acordo com estimativas, para que o SNUC funcione plenamente, seriam necessários gastos correntes anuais da ordem de R\$543 milhões para o sistema federal e de R\$ 361 milhões para os sistemas estaduais, além de R \$ 611 milhões em investimentos em infraestrutura e planejamento no sistema federal e de outros R \$ 1,18 bilhão nos sistemas estaduais (MEDEIROS, YOUNG, 2011, p.16).

Ainda que fosse somado a esse valor, os custos necessários para promover a desapropriação para regularização fundiária (estimados pelo MMA em um bilhão de reais anuais pelos próximos 20 anos para custear somente o passivo federal), tal montante é irrisório se comparado, por exemplo, aos recursos destinados às obras do Programa de Aceleração do Crescimento (PAC) do governo federal, o que demonstra que o tema da conservação ainda não é prioritário para o poder público nas suas diferentes esferas (RANIERE, et. al., 2011, p. 153).

O sistema brasileiro de UCs como em outros países é sustentado fundamentalmente com recursos públicos. A fim de suprir a falta de investimento de recursos orçamentários no setor, se observa a crescente busca por fontes alternativas de financiamento para o sistema. Recursos oriundos de agências multilaterais e de fundos nacionais e/ou internacionais. Pari passo, os recursos de compensação ambiental advindos de empreendimentos cujos impactos ambientais são considerados significativos têm sido importantes fontes de financiamento para algumas unidades. Salienta-se, todavia que em face da escassez de financiamento ao invés de haver uma repulsa à construção de obras de grande impacto ambiental no entorno das unidades, pode ocorrer o interesse por parte delas em ter um empreendimento dessa natureza nas suas proximidades em função da expectativa na entrada de recursos. Alguns atores advogam que para evitar este problema a compensação deveria adotar uma lógica diferente da atual e fazer com que os percentuais a serem destinados para compensação 
ambiental fossem cada vez mais altos quanto maior fosse à proximidade e os impactos dos empreendimentos em relação às unidades de conservação (RANIERE, et. al., 2011, p. 153,154$)$.

Outras fontes de recursos despontam nas discussões atuais sobre financiamento de unidades de conservação, uma das que tem tido maior destaque é o pagamento por serviços ambientais (PSA), que será tratado no último capítulo deste trabalho, embora ainda existam dúvidas a respeito da efetividade, eficácia, equitabilidade e dos benefícios gerados por estes programas.

Dificuldades de aplicação das restrições de uso dos recursos naturais para as comunidades locais e a tomada de decisões de manejo com poucos dados ecológicos ilustram dificuldades de gestão (BENSUSAN, 2006, p. 24 - 26).

Neste ínterim, a questão das populações residentes nas unidades ou em seu em torno se revela uma grande dificuldade. A exclusão das populações é essencialmente injusta, pois implica uma distribuição desigual de sacrifícios, vez que populações que são privadas de terras que tradicionalmente ocuparam, e contribuíram para conservação, sendo muitas vezes, realocadas em locais e condições indefensáveis (BENSUSAN, 2006, p. 27).

Por fim, mas não menos importante, o monitoramento da eficiência da unidade de conservação é assaz complexo na medida em que indicadores de sucesso de conservação são difíceis de obter, embora conjuntos de indicadores estejam sendo desenvolvidos e aplicados com êxito. O desenho de uma determinada área de conservação depende além de seu tamanho e forma, da existência de zonas de amortecimento e de conexões entre ela e outras áreas, um desenho não adequado conduz à hábitats fragmentados e ilhas de conservação. Dentre os requisitos da eficiência podese destacar ainda, a verificação das técnicas de manejo e se estas respondem aos desafios cotidianos da área, incluindo o planejamento, a capacitação e a resolução de conflitos (BENSUSAN, 2006, p. 29).

No que tange a estes últimos, embora tenha havido melhorias também no que diz respeito à elaboração dos planos de manejo, nota-se ainda que estes são pouco funcionais, muito descritivos e pouco condizentes com a realidade do sistema, apresentando recomendações pouco aplicáveis à gestão da unidade. Por apresentarem essas características, deixam de ser uma ferramenta que o gestor da unidade deveria estar constantemente utilizando em suas ações (RANIERE, et. al., 2011, p. 157). 
Aqui, o desafio se amplia na medida em que falta conhecimento sobre a totalidade dos processos que geram e mantêm a biodiversidade, cuja integridade deve ser preservada, e a necessidade concomitante da ação. Este é o desafio fundamental da biologia da conservação: não é possível obter todos os dados para começar a agir, manejar e gerir, pois a biodiversidade está continuamente ameaçada, inclusive nas áreas protegidas (BENSUSAN, 2006, p. 55).

Aliados a todos estes fatores, acrescenta-se a ausência de fiscalização, o fato de o Brasil possuir uma das maiores relação de área protegida por funcionário do mundo, revela a urgência de recomposição do quadro funcional não apenas em termos de novas contratações, mas também de treinamento adequado.

Apesar dos pontos positivos e negativos levantados acima, há que se reconhecer que o SNUC consolidou as normas esparsas relativas às UC no país em uma única lei, facilitando a aplicação da norma e o gerenciamento do sistema, estabeleceu a obrigatoriedade da elaboração dos planos de manejo, previu a participação pública nos processos de criação e gestão das unidades e incorporou conceitos como os de corredores de biodiversidade e mosaicos de unidades de conservação com o intuído de evitar a fragmentação de habitats.

\section{2) Código Florestal: Áreas de Preservação Permanente e Reserva Legal}

\section{1) Histórico e Regime Jurídico do Código Floresta de 1965}

Em uma das primeiras obras sobre o regime jurídico florestal no Brasil, o Magistrado Osny Duarte Pereira (1950, p.17) afirmou que em diversos países, ao longo do tempo, a necessidade de que o Estado regulasse a conservação das florestas fez com fossem organizados Códigos, nestes a intervenção do poder estatal variava conforme a tendência da Constituição.

No regime liberal as leis florestais eram orientadas no sentido da completa ausência de intervenção do Estado na atividade particular, caso se entendesse que o particular estava utilizando as floretas contra a sociedade, impunha-se a desapropriação de suas terras. No regime eclético a intervenção era moderada, ou seja, o particular mantinha a administração plena de suas florestas, mas o Estado reserva se o direito de proibir ou regular o corte em alguns casos, a redução dos direitos do proprietário era 
compensada por uma indenização, as leis florestais do século XIX teriam sido deste tipo. Por fim, no regime intervencionista, o Estado intervém de maneira direta e ostensiva no resguardo das floretas, tendo-as como bem de interesse coletivo. (PEREIRA, 1950, p.18-20).

No Brasil, sempre houve a prevalência deste último regime. Enquanto colônia a intervenção não possuía objetivos conservacionistas, mas, tão somente a manutenção dos benefícios da Coroa Portuguesa. Foi somente no período republicano que o país passou a contar com uma codificação florestal, antes as leis eram esparsas. Observa-se, entretanto, que a Constituição Federal de 1981, de cunho marcadamente liberal silenciava quanto a proteção florestal, concedendo direitos absolutos e ilimitados sobre a propriedade da terra (AHRENS, 2010, p.65).

O Código Florestal de 1934, primeira codificação florestal brasileira, foi elaborado por uma Comissão e teve como relator Luciano Pereira da Silva. De maneira inovadora, este documento classificou as florestas em: protetoras, remanescentes, modelo e de rendimento. As florestas protetoras eram um esboço do instituto das florestas de preservação permanente do atual Código Florestal. As florestas remanescentes, por sua vez, eram formadas por áreas hoje denominadas unidades de conservação; as florestas modelo constituíam as florestas plantadas com limitado número de essências florestais, nativas ou exóticas, e finalmente as florestas de rendimento, eram aquelas não previstas entre as outras modalidades e destinadas ao uso intensivo dos recursos florestais. O Código Florestal de 1934, também introduziu dispositivos de natureza penal (RESENDE, 2006, p.76).

Segundo Ahrens (2003), citado por (RESENDE, 2006, p. 77) para entender o que motivou o Código Florestal de 1934, faz-se necessário entender a realidade socioeconômica e política da sociedade brasileira no século XX. De maneira breve pode-se dizer que a população estava concentrada próxima à Capital da República, Rio de Janeiro. A terra era utilizada basicamente para a cafeicultura e agropecuária, à custa da derrubada da vegetação nativa e sem a mínima técnica. No restante do país, a atividade florestal era fundamentada no mais puro extrativismo. Neste contexto o Poder Público decidiu interceder, estabelecendo limites através do Código Florestal.

Todavia, em virtude das dificuldades verificadas para a efetiva implementação do Código Florestal de 1934, elaborou-se proposta para um novo diploma legal que pudesse normatizar adequadamente a proteção jurídica do patrimônio florestal brasileiro. Foi remetido ao Congresso Nacional por meio da Mensagem Presidencial 
04/1950, em janeiro de 1950. O projeto do novo código florestal procurava avançar no entendimento jurídico da matéria, sem alterar, contudo, a essência do seu conteúdo conceitual e jurídico (RESENDE, 2006, p.85). A Tramitação do projeto iniciou-se pelo "Projeto Daniel de Carvalho" que após sofrer diversas alterações foi sancionado em 15 de setembro de 1965 pela Lei 4.771, que revogou o Código anterior de 1934 (RESENDE, 2006, p. 85).

O Código Florestal de 1965 definiu claramente duas linhas de política para os recursos florestais brasileiros. A primeira de proteção, ao estabelecer as florestas de preservação permanente, reserva legal e as áreas de uso indireto (Parques Nacionais e Reservas Biológicas) e, a segunda de conservação através do uso racional, ou seja, a exploração das florestas plantadas e nativas vinculando o consumo a reposição florestal, o uso múltiplo através da exploração das áreas públicas (Florestas Nacionais) e privadas (RESENDE, 2006, p.87).

A análise permite observar que o Código Florestal de 1965 de maneira geral tinha como propósito proteger não apenas as árvores e florestas, estas eram na realidade um meio para atingir outros fins. Buscava-se proteger os solos contra a erosão, as águas, os cursos d'água, os reservatórios de água naturais e artificiais, entre outros (AHRENS, 2010, p.73,74).Os objetivos acima deveriam ser alcançados por meio da proteção das florestas e das demais formas de vegetação. Isto demonstra o caráter sistêmico do referido código.

O Código Florestal de 1965 conferia, portanto, alto grau de proteção não apenas aos ecossistemas florestais, mas também a outras formas de vegetação encontradas nas áreas de preservação permanente (APPs) e nas áreas de reserva lega (RL).

De acordo com Silva (2010, p.171) o mais importante do ponto de vista jurídico protecionista do Código Florestal de 1965 foi à adoção do conceito de floresta de preservação permanente, que não se limitara a reproduzir o conceito de floresta protetora do código anterior, mas era bem mais abrangente, abrindo possibilidade à atuação mais ampla do Poder Público.

A definição legal da Área de Preservação Permanente (APP) foi dado pela Medida Provisória no 2.166-67, de 24 de agosto de 2001, que alterou o Código Florestal de 1965, e conceituava APP como área coberta ou não por vegetação nativa, com a função ambiental de preservar os recursos hídricos, a paisagem, a estabilidade geológica, a biodiversidade, o fluxo gênico de fauna e flora, proteger o solo e assegurar o bem estar das populações humanas. O Código Florestal de 1965, nos arts. $2^{\text {o }}$ e $3^{\circ}$, 
dispunha sobre a matéria, sendo que cada um desses dispositivos tratava dos espaços de forma distinta.

As Áreas de Preservação Permanente (APP) previstas no art. $2^{\circ}$ possuíam como distintivo em relação aos demais espaços protegidos, seu ato de criação. O Código Florestal instituía a proteção dessas áreas pelo só efeito da lei, ou seja, em função de sua localização. Disso decorria que as APP's podiam incidir tanto sobre o patrimônio público como sobre o particular, a depender do domínio das áreas onde se localizassem. A localização, os parâmetros, as definições e os limites das APP encontravam- se estabelecidos, além do art. $2^{\circ}$, do Código Florestal, na Resolução CONAMA nº 303, de 20 de março de 2002 (GRANZIERA, 2011, p. 446, 447).

$\mathrm{O}$ art. $3^{\circ}$, do Código Florestal também dispunha sobre as APP, porém de maneira distinta, "quando assim declaradas por ato do Poder Público". Diversamente dos espaços objeto do art. $2^{\circ}$, as APPs do art. $3^{\circ}$ deste Código Florestal deveriam ser declaradas por ato particular, relativo a cada espaço protegido. "O critério não era o da localização, mas o da proteção do meio ambiente ou da segurança de pessoas e bens" (GRANZIERA, 2011, p. 449, 450).

Aludido dispositivo, no que se refere à proteção de espaços merece destaque porque na época da edição do Código Florestal, não havia outro instrumento legal para prever a declaração de um espaço como protegido, além daquelas definidas nos arts. $2^{\circ} \mathrm{e}$ $5^{\circ}$ (GRANZIERA, 2011, p. 450).

Como o Código não minudenciava qualquer regra adicional, o respectivo regime jurídico de proteção era estabelecido no ato de criação da área, até mesmo no que se refere ao seu regime dominial, se de direito público ou privado (GRANZIERA, 2011, p.450).

Entretanto, como bem observa Granziera (2011, p.450) com o advento da legislação ambiental e principalmente da Lei $\mathrm{n}^{\circ} 9.985$ de 2000, Lei do SNUC, formando um amplo leque de alternativas para a instituição e a gestão dos espaços protegidos, a criação de novas APPs com base no art. $3^{\circ}$ do Código Florestal para fins de proteção do ambiente diminuiu seu valor. A autora aduz, todavia, que continuaram em vigor as áreas já declaradas ao longo do tempo com base nesse dispositivo.

No que se refere ao regime jurídico o proprietário embora permanecesse na posse no espaço não poderia fazer intervenções na área nem tampouco suprir sua vegetação, exceto pelas hipóteses previstas pela MP n² 2.166-67 de 2001 e pela Resolução CONAMA n 369, que dispunham sobre as hipóteses de supressão de 
cobertura vegetal por motivo de utilidade pública, interesse social e baixo impacto ambiental.

Pela limitação administrativa imposta ao uso não havia possibilidade do proprietário da área receber qualquer indenização, já que a proteção dessas áreas era e é reflexo da função social e ambiental da propriedade.

Lado outro, a Reserva Legal surgiu no ordenamento pátrio pela primeira vez no Código Florestal de 1934 que em seu art. 223 determinava que 25\% da área da propriedade rural coberta por florestas não poderia ser derrubada, a menos que fosse para a transformação de florestas heterogêneas em homogêneas, destinadas à exploração florestal (MAGALHÃES, 2010, p.232).

Com o advento do Código Florestal de 1965 e com as sucessivas modificações que este sofreu, em particular pela Medida Provisória 2.166-67 de agosto de 2001 a reserva legal ficou definida como a "área localizada no interior de uma propriedade ou posse rural, excetuada a de preservação permanente, necessária ao uso sustentável dos recursos naturais, à conservação e reabilitação dos processos ecológicos, à conservação da biodiversidade e ao abrigo e proteção de fauna e flora nativas". ${ }^{13}$

O arcabouço jurídico da Reserva Legal, previsto na MP no 2.166-67 de 2001, dispunha que um percentual da propriedade fosse destinado à proteção do meio ambiente. A sua localização deveria ser determinada segundo a opção que pudesse proporcionar o maior fluxo gênico possível entre as espécies, evitando-se, ao máximo, a formação de ilhas de proteção. O conceito que fundamentava a Reserva Legal era a ligação desses espaços com outras áreas protegidas, como é o caso das Áreas de Preservação Permanente (APP), ou das Unidades de Conservação (GRANZIERA, 2011, p.473).

Em relação ao regime jurídico a Reserva Legal incidia unicamente sobre as propriedades localizadas em área rural e em face de seu escopo de conservação ambiental, infligia restrições ao uso da propriedade, sem gerar, contudo, indenização. A posse/propriedade do espaço continuava com o proprietário, que poderia fazer uso da área sob regime de manejo florestal sustentável, de acordo com princípios e critérios técnicos e científicos estabelecidos no regulamento (GRANZIERA, 2011, p.475).

O percentual da reserva legal era variável em função da localização e da natureza da vegetação. Segundo, a lei os percentuais mínimos para as diversas regiões

13 Lei $n^{\circ} 4.771 / 65$, art. $1^{\circ}, \S 2^{\circ}$, III, com a redação dada pela MP nº $2.166-67 / 01$. 
brasileiras, no que se alude à necessidade de manutenção de florestas e outras formas de vegetação nativa era:

1. $80 \%$ na propriedade rural situada em área de floresta localizada na Amazônia Legal;

2. $35 \%$ na propriedade rural situada em área de cerrado localizada na Amazônia Legal, sendo no mínimo $20 \%$ na propriedade e $15 \%$ na forma de compensação em outra área, desde que esteja localizada na mesma microbacia, e seja averbada junto à matrícula do imóvel;

3. $20 \%$ na propriedade rural situada em área de floresta ou outras formas de vegetação e em área de campos gerais nativa localizada nas demais regiões do país. ${ }^{14}$

A localização e a delimitação da área destinada à Reserva Legal eram sugeridas pelo proprietário ou posseiro, e tinham que ser admitidas pelo órgão ambiental estadual competente: o plano de bacia hidrográfica; o plano diretor municipal; o zoneamento ecológico-econômico; outras categorias de zoneamento ambiental; a proximidade com outra Reserva Legal, Área de Preservação Permanente, Unidade de Conservação ou outra área legalmente protegida (GRANZIERA, 2011, p.476).

A área destinada à Reserva Legal precisava ser averbada à margem da inscrição de matrícula do imóvel, no registro de imóveis competente. Depois da averbação a mudança ou alteração da destinação, nos casos de transmissão, a qualquer título, de desmembramento ou de retificação da área, com as exceções previstas no Código Florestal eram proibidas (GRANZIERA, 2011, p.477) ${ }^{15}$.

Pode-se dizer de maneira geral que o principal problema do Código Florestal de 1965, tal qual o de 1934 foi seu descumprimento. Como exemplo tem-se a legislação sobre Área de Preservação Permanente e Reserva Legal que sempre foi muito desrespeitado, no passado, no Centro-Sul do País e atualmente nas áreas de expansão da fronteira agrícola. Para uma efetiva implementação desta lei florestal era necessário à solução do passivo ambiental dos proprietários rurais e a introdução de estímulos econômicos efetivos, como por exemplo, através de isenção de impostos (RESENDE, 2006, p.89).

Com o desmatamento desenfreado e sob quaisquer circunstâncias e o mau manejo dos solos, fomos perdendo terras agrícolas, assoreando rios, entupindo vales,

14 Lei $n^{\circ} 4.771 / 65$, art. 16, com a redação dada pela MP no $2.166-67 / 01$.

15 Lei $n^{\circ} 4.771 / 65$, art. $16, \S 8^{\circ}$, com a redação dada pela MP nº 2.166-67/01. 
provocando enormes erosões, agravando o quadro das enchentes, poluindo rios e lagos, salinizando terras outrora férteis e até começando processos de desertificação, tanto no Nordeste semi-árido como no Rio Grande do Sul. E tudo isso acontecendo em plena vigência do Código Florestal que se não era uma lei perfeita, pelo menos se houvesse sido obedecida mostraria um painel distinto do atual (RESENDE, 2006, p.89-90).

Deste modo o Código Florestal de 1965 foi alterado, ao longo dos anos, no sentido de adequá-lo às peculiaridades e necessidades da atualidade. A alteração mais abrangente como dito anteriormente foi feita por meio da Medida Provisória ${ }^{\circ}$ 2.16667, de 24 de agosto de 2001, que alterou os arts. $1^{\circ}, 4^{\circ}, 14,16$ e 44 e acresceu dispositivos ao Código Florestal. Esta medida provisória é fruto de sucessivas medidas provisórias reeditadas, neste período ocorreram constantes embates entre "ruralistas" e "ambientalistas".

Estas alterações causaram insegurança jurídica, pois, as Áreas de Preservação Permanentes e a Reserva Legal, permaneceram por muito tempo reguladas apenas por medida provisória. A sucessão de medidas provisórias gerou uma série de discussões, já que ao mesmo tempo em que ostentavam grau aceitável e necessário de proteção ambiental introduziam uma série de flexibilizações. Referidas medidas não possuíam os requisitos de urgência e relevância, o que poderia dar azo à inconstitucionalidade formal das mesmas.

Durante treze anos intensos debates surgiriam em relação ao código florestal. Críticas em relação á sua efetividade, sobre os altos custos da conservação que recairiam somente sobre os proprietários rurais, à suposta arbitrariedade na definição das metragens estabelecidas para as APPs, a falta de terras para a agricultura, entre outras.

A situação tornou-se mais agravante com o avanço agrícola das monoculturas e da pecuária extensiva e principalmente após a edição da Lei no 9.605 de 1998, a chamada Lei de Crimes Ambientais, que estabeleceu tipos penais relativos à infringência dos preceitos do Código Florestal.

Progressivamente a pressão para que o Código fosse efetivamente cumprido foi surgindo, e os debates se acentuando tanto que segundo dados colhidos por Roseli Ganem e Suely de Araujo, em janeiro de 2010, existiam 36 projetos em tramitação na Câmara dos Deputados, pretendendo alterar o Código Florestal. O que ganhou maior notoriedade foi Projeto de Lei $\mathrm{n}^{\circ}$. 1876 de 1999, cujo relator era o deputado federal Aldo Rebelo (PC do B/SP). Referido substitutivo, foi aprovado no dia 06 de julho de 
2010 pela comissão especial da Câmara dos Deputados, e carregava em seu bojo intricadas disposições acerca das Áreas de Preservação Permanente (APP), de Reserva Legal (RL) e anistia de crimes ambientais ocorridos até aquele momento.

Após uma tumultuada tramitação e um longo e polêmico processo no Congresso Nacional com discussões veementes por parte de ambientalistas e ruralistas e com a temática ganhando grande espaço nas mídias sociais no dia 25 de maio de 2012, a presidente Dilma Rousseff sancionou com vetos a Lei $\mathrm{n}^{\circ}$. 12.651. Devido à extensão dos vetos, a presidente também editou a Medida Provisória 571, que buscou preencher as lacunas e ir além, restaurando um acordo feito entre o governo e a bancada ruralista durante a tramitação do Projeto de Lei no Senado. O resultado (PL com vetos combinados com MP) tem sido defendido por governistas, levemente criticado pelos ruralistas e fortemente criticado pelos ambientalistas.

No próximo tópico serão analisadas algumas das mudanças introduzidas por este Novo Código Ambiental em especial as refrentes às APP's e Reservas Legais.

\subsection{2) Áreas de Preservação Permanente e Reserva Legal: principais mudanças do Novo Código Florestal}

Antes de se falar especificamente sobre as mudanças que incidiram nas áreas de preservação permanente, falar-se-á mesmo que brevemente sobre algumas das outras mudanças introduzidas pela lei $\mathrm{n}^{\mathrm{o}} 12.651$ de 2012.

Em muitas passagens o novo Código Florestal adota dois regimes jurídicos: um de tolerância para as condutas lesivas ao ambiente perpetradas até o dia 22 de julho de 2008 e outro mais rígido para os atos praticados a partir dessa data. Isso ocorre porque, no dia 23 de julho de 2008, foi publicado o Decreto $n^{\circ} 6.514$, que dispunha sobre as infrações e sanções administrativas ao meio ambiente, e que instituiu uma série de novos tipos administrativos para punir os infratores da legislação ambiental.

Salienta-se, outrossim, que o novo Código possui disposições mais flexíveis em favor do pequeno proprietário ou possuidor rural (prédio rústico de até 04 módulos fiscais), especialmente no que concerne às áreas de preservação permanente e reserva legal.

Outra mudança do novo Código foi a previsão de criação do CAR - Cadastro Ambiental Rural, no âmbito do Sistema Nacional de Informação sobre Meio Ambiente, 
registro público eletrônico de âmbito nacional, obrigatório para todos os imóveis rurais, com a finalidade de integrar as informações ambientais das propriedades e posses rurais, compondo base de dados para controle, monitoramento, planejamento ambiental e econômico e combate ao desmatamento, devendo ser feito, preferencialmente, no órgão ambiental municipal ou estadual ( artigo 29). Neste sentido, nos termos do se artigo 78A, após cinco anos da data da publicação novo código, as instituições financeiras só concederão crédito agrícola, em qualquer de suas modalidades, para proprietários de imóveis rurais que estejam inscritos no Cadastro Ambiental Rural e que comprovem a sua regularidade florestal.

Também foi prevista a instituição, pelas entidades políticas, no prazo de 01 ano após a publicação do novo Código Florestal, prorrogável uma vez por igual período, dos Programas de Regularização Ambiental - PRA's, que objetivam regularizar os imóveis rurais no que concerne às situações consolidadas até 22 de julho de 2008 nas áreas de reserva legal e de preservação permanente, cuja assinatura do termo de compromisso repercutirá na esfera administrativa e criminal com a extinção da punibilidade, além da civil (artigo 59).

Outros três programas foram introduzidos pelo novo código florestal, quais sejam: Programa de Apoio e Incentivo à Conservação do Meio Ambiente (artigo 41) - a ser instituído pelo Poder Executivo federal, para adoção de tecnologias e boas práticas que conciliem a produtividade agropecuária e florestal, com redução dos impactos ambientais, como forma de promoção do desenvolvimento ecologicamente sustentável, observados sempre os critérios de progressividade; Programa para Conversão da Multa prevista no art. 50 do Decreto n ${ }^{\circ}$ 6.514, de 22 de julho de 2008 (artigo 42) - a ser instituído pelo Poder Executivo federal, destinado aos imóveis rurais, referente a autuações vinculadas a desmatamentos promovidos sem autorização ou licença, em data anterior a 22 de julho de 2008; e Programa de Apoio Técnico e Incentivos Financeiros (artigo 58) - a ser instituído pelo Poder Público, para atendimento prioritário dos pequenos proprietários e possuidores rurais, podendo incluir medidas indutoras e linhas de financiamento.

Os programas acima acabam por incorporar em um de seus eixos de atuação os instrumentos econômicos, autorizando o Poder Executivo a instituí-los seja na forma de isenções ou de pagamento por serviços ambientais. Embora a medida seja benéfica a priori, faz-se necessário esperar pela regulamentação e definição dos contornos dos mesmos para que se possa avaliar a medida. 
No que se refere às APPs o conceito permaneceu o mesmo o artigo $2^{\circ}$, do antigo Código Florestal, reproduziu-se literalmente a redação do artigo $1^{\circ}$, do Código revogado. As áreas de preservação previstas no artigo $4^{\circ}$ são ex legi e as do art. $6^{\circ}$ precisam ser declaradas por ato do poder executivo para existir.

Em relação à delimitação das áreas de preservação permanente a primeira mudança diz respeito à alteração do critério de delimitação das APPs relativas às faixas marginais e corpos de água fluente. No Código Florestal antigo as APPs situadas em as faixas marginais deveriam ser medidas a partir do nível mais alto do curso d'água, no que era seguido pela Resolução CONAMA nº 303 de 2002. Nível mais alto, segundo o art. $2^{\circ}$, inciso I da referida Resolução, corresponde ao "nível alcançado por ocasião da cheia sazonal do curso d'água perene ou intermitente".

O Novo Código Florestal, por sua vez, determina que as APPs nas faixas marginais aos cursos d'água naturais devem ser mensuradas a partir da borda do leito menor, isto é, " a calha por onde correm regularmente as águas do curso d'água durante o ano" (art. $3^{\circ}$, inciso XIX). Observa-se, portanto, que a inserção do conceito de leito menor, ao modificar o critério de delimitação das APPs localizadas nas faixas marginais a cursos d'águas, tem por finalidade diminuir a extensão dessas áreas ${ }^{16}$.

Isso porque a largura mínima (metragem) da vegetação de APP passa a ser definida com base em um espaço ocupado por uma quantidade menor de água (leito menor ou de estiagem) em relação às épocas de cheias (leito maior ou de inundação), de modo que o alcance territorial das águas dos cursos d'água também é menor. "Pode parecer pouca diferença, mas se esta diminuição for multiplicada pelas 5,7 milhões de propriedades rurais existentes no Brasil, sem contarmos as posses, e que muitas destas propriedades são latifúndios de milhares de hectares, ela pode significar a não recuperação e a destruição das florestas ainda existentes em milhões de hectares no Brasil” (MAGALHÃES, 2010, p. 59). A segunda mudança foi a exclusão dos cursos d'água efêmeros, que são aqueles que somente ocorrem quando há fortes chuvas.

\footnotetext{
16 "Tais zonas alagadas laterais ("wetland pools") são biorreatores de processamento de matéria orgânica e estocagem temporária de nutrientes; durante as águas baixas, essas áreas recebem materal alóctone (p.ex., folhas, sementes, insetos) e trocam esse material com o curso d'água durante as cheias. A ausência dessas trocas pode afetar diretamente a produção íctica" (Carlos A. Joly, Jean Paul Metzger, Lilian Casatti, Luiz A. Martinelli, Ricardo R. Rodrigues e Thomas M. Lewinsohn, Impactos potenciais das alterações propostas para o Código Florestal Brasileiro. p. 3.2011. Disponível em: http://www2.unesp.br/revista/wp-content/uploads/2010/10/Biota-Fapesp-ABECO-Sintese-CFB-ebiodiversidade.pdf
} 
O antigo Código Florestal apenas previa o redor dos lagos e lagoas como áreas de preservação permanente sem fixar a sua dimensão, o que foi feito pelo artigo $3^{\circ}$, inciso III, da Resolução CONAMA 303 de 2002. Atualmente, consideram-se áreas de preservação permanente as áreas no entorno dos lagos e lagoas naturais, em faixa com largura mínima de: a) 100 metros, em zonas rurais, exceto para o corpo d'água com até 20 hectares de superfície, cuja faixa marginal será de 50 metros; b) 30 metros, em zonas urbanas. Por outro lado, nos termos do artigo $4^{\circ}, \S 4^{\circ}$, do novo Código, fica dispensado o estabelecimento das faixas de Área de Preservação Permanente no entorno das acumulações naturais ou artificiais de água com superfície inferior a 01 hectare, vedada nova supressão de áreas de vegetação nativa.

O novo código excluiu as APPs para reservatórios artificiais que não forem decorrentes de barramentos de cursos d'água naturais. No mesmo sentido o $\S 1^{\circ}$ do art. $4^{\text {o }}$ da lei dispõe: Não será exigida Área de Preservação Permanente no entorno de reservatórios artificiais de água que não decorram de barramento ou represamento de cursos d'água naturais. (Redação dada pela Lei $n^{\circ} 12.727$, de 2012). Houve também a exclusão das nascentes intermitentes. A medida terá grave consequências para os biomas da Caatinga e Cerrado, nos quais a grande maioria das nascentes são intermitentes. $^{17}$

Lado outro a previsão dos manguezais em toda a sua extensão como áreas de preservação ambiental foi uma boa inovação do novo código. $\mathrm{O}$ anterior apenas previa as restingas estabilizadoras dos mangues como APP's. Os manguezais em toda a sua extensão apenas eram previstos como áreas de preservação permanente pelo artigo $3^{\circ}$, inciso X, da Resolução CONAMA nº 303 de 2002.

O Novo Código diminuiu ainda a proteção em topos de morros, montes e serras a partir da fixação de altura mínima e outros parâmetros para a proteção. Nesta mesma linha o novo código determina que as veredas só estarão protegidas numa faixa marginal, em projeção horizontal, de 50 metros a partir do "espaço permanentemente brejoso e encharcado" (art. $4^{\circ}$, inciso XI), o que diminui muito sua área de proteção. Antes, a área alagada durante a época das chuvas era resguardada. Além desse limite, o desmatamento será permitido. As veredas são fundamentais para o fornecimento de água, pois são responsáveis pela infiltração de água que alimenta as nascentes da

\footnotetext{
${ }^{17}$ Informação disponível em: http://amazonia.org.br/2012/10/\%E2\%80\%9Co-novo-c\%C3\%B3digo$\% \mathrm{C} 3 \% \mathrm{~A} 9-$-cheio-de-contradi\%C3\%A7\%C3\%B5es-e-ambiguidades\%E2\%80\%9D-afirma-assessor-do-isa/
} 
Caatinga e do Cerrado, justamente as que secam durante alguns meses do ano em função do estresse hídrico. ${ }^{18}$

Em relação às áreas de preservação administrativas a primeira mudança refere-se à competência para dizer quais serão as APPs administrativas no antigo código podia ser por ato do poder público no Novo Código está restrito ao Chefe do Poder Executivo, quando declaradas de interesse social. A segunda mudança refere-se ao rol das situações que foi modificado em alguns incisos.

O regime de proteção das áreas também foi alterado a exigência de alternativa técnica e locacional ao empreendimento proposto foi excluída. Existem também diferenças quanto à definição das situações que permitem a supressão de vegetação ou intervenção (ocupação, por exemplo) em APP, ou seja, utilidade pública, interesse social e baixo impacto ambiental, como se verá a seguir:

Nas hipóteses de utilidade pública a primeira mudança foi competência para dizer quais eram os casos de utilidade pública que antes eram do CONAMA agora são do Chefe do executivo federal. A segunda refere-se à mudança do rol com destaque para inclusão de obras para instalações necessárias para competições esportivas. Impossível não recordar neste caso das Olimpíadas e Copa do Mundo que serão realizadas no país.

Tal como previsto para a definição de atividades de utilidade pública, as demais hipóteses de interesse social, também devem ser estabelecidas por ato do chefe do Poder Executivo Federal.

No caso das atividades de baixo impacto foram mantidas as competências do CONAMA e dos Conselhos Estaduais para reconhecerem novas atividades de baixo impacto.

Ainda é admitido pelo artigo $4^{\circ}, \S 5^{\circ}$, do novo Código, nas pequenas propriedades ou posses rurais familiares, o plantio de culturas temporárias e sazonais de vazante de ciclo curto na faixa de terra que fica exposta no período de vazante dos rios ou lagos, desde que não implique supressão de novas áreas de vegetação nativa, seja conservada a qualidade da água e do solo e seja protegida a fauna silvestre.

Nas matas ciliares e nas APP's no entorno de lagos e lagoas naturais, o permissivo novo Código Florestal permite o desenvolvimento da aquicultura e infraestrutura física diretamente a ela associada nos imóveis com até 15 módulos fiscais, desde que: I - sejam adotadas práticas sustentáveis de manejo de solo e água e de

\footnotetext{
${ }^{18}$ Carta da SBPC à Presidenta Dilma Rousseff. Disponível em: < http://www.sbpcnet.org.br/site/noticias/mostra.php?id=1766> .
} 
recursos hídricos, garantindo sua qualidade e quantidade, de acordo com norma dos Conselhos Estaduais de Meio Ambiente; II - esteja de acordo com os respectivos planos de bacia ou planos de gestão de recursos hídricos; III - seja realizado o licenciamento pelo órgão ambiental competente; IV - o imóvel esteja inscrito no Cadastro Ambiental Rural - CAR.

Quanto à controversa possibilidade de cômputo das áreas de preservação permanente nas áreas de reserva legal o Novo Código prevê que a área de APP que poder ser somada no cálculo da reserva legal não mais se restringe à "vegetação nativa em área de preservação permanente", como o fazia o código anterior. Exige-se tão somente que "a área esteja conservada ou em processo de recuperação, conforme declaração do proprietário ao órgão estadual ou municipal integrante do SISNAMA". Ou seja, as áreas de APP poderão ser sempre somadas no cálculo do percentual da RL, já que deixa de existir limitações à possibilidade de computá-las.

O maior objetivo desta alteração é a redução do passivo ambiental, uma vez que esse mecanismo não deverá ser autorizado caso ele implique na supressão de novas áreas de vegetação nativa. ${ }^{19}$

A comunidade científica em sua maioria aduz que as áreas de preservação permanente não poderiam ser incluídas no cômputo das Reservas Legais do imóvel. Já que as comunidades biológicas, as estruturas e as funções ecossistêmicas das APPs e das reservas legais (RLs) são distintas. A ABC (Associação Brasileira Científica) e a SBPC( Sociedade Brasileira de Pesquisa Científica) sempre defenderam que a eventual compensação de déficit de RL fosse feita nas áreas mais próximas possíveis da propriedade, dentro do mesmo ecossistema, de preferência na mesma microbacia ou bacia hidrográfica. No entanto, as alterações na MP 571 de 2012 mantêm mais ampla a possibilidade de compensação de RL no âmbito do mesmo bioma, o que não assegura a equivalência ecológica de composição, de estrutura e de função. Mantido esse dispositivo, sua regulamentação deveria exigir tal equivalência e estipular uma distância máxima da área a ser compensada, para que se mantenham os serviços ecossistêmicos regionais. A principal motivação que justifica a RL é o uso sustentável dos recursos naturais nas áreas de menor aptidão agrícola, o que possibilita conservação da

\footnotetext{
${ }^{19}$ Carlos A. Joly, Jean Paul Metzger, Lilian Casatti, Luiz A. Martinelli, Ricardo R. Rodrigues e Thomas M. Lewinsohn, Impactos potenciais das alterações propostas para o Código Florestal Brasileiro. p.6. Disponível em: http://www2.unesp.br/revista/wp-content/uploads/2010/10/Biota-Fapesp-ABECOSintese-CFB-e-biodiversidade.pdf
} 
biodiversidade nativa com aproveitamento econômico, além da diversificação da produção" ${ }^{20}$.

O texto ainda considera que no referido cômputo se poderá considerar todas as modalidades de cumprimento da Reserva Legal, ou seja, regeneração, recomposição e compensação (Art. $15 \S 3^{\circ}$ ). Também é facultado ao proprietário ou possuidor de imóvel com RL conservada e averbada, cuja área ultrapasse o mínimo exigido, instituir servidão ambiental ou outros instrumentos congêneres sobre a área excedente.

Por fim, o proprietário que possuir mais de $80 \%$ da propriedade em APPs somadas as demais florestas na Amazônia legal poderá converter áreas para o uso alternativo do solo.

Áreas consolidadas em APP's reguladas pelo novo Código Florestal são um dos temas mais controversos e difícil interpretação do novo código. O tema é tratado no Capítulo XIII, Seção II,nos artigos 61-A a 65, tendo sido tomado como marco legal divisor do regime jurídico o dia 23 de julho de 2008, quando foi publicado o Decreto 6.514. O artigo 61-A prevê que, "nas áreas de preservação permanente é autorizada, exclusivamente, a continuidade das atividades agrossilvipastoris, de ecoturismo e de turismo rural em áreas rurais consolidadas até 22 de julho de 2008", devendo ser monitoradas no Cadastro Ambiental Rural e adotadas medidas de mitigação dos impactos ambientais para a conservação do solo e das águas pelo proprietário ou possuidor que deverá adotar boas práticas agronômicas, sendo vedada a conversão de novas áreas para uso alternativo do solo nesses locais.

Assegurou-se que, a partir da data da publicação do novo Código (28.05.2012) e até o término do prazo de adesão ao Programa de Regularização Ambiental (um ano após a criação do referido cadastro), é autorizada a continuidade das referidas atividades desenvolvidas nas APP's, as quais deverão ser informadas no Cadastro Ambiental Rural, para fins de monitoramento, sendo exigida a adoção de medidas de conservação do solo e da água.

Os proprietários e possuidores rurais com áreas consolidadas em APP ao longo dos cursos d'água, deverão recompor as faixas marginais a partir da borda da calha do leito regular, variando a dimensão da mata ciliar a ser recomposta de acordo com o tamanho do imóvel rural.

\footnotetext{
${ }^{20}$ Carta da SBPC à Presidenta Dilma Rousseff. Disponível em: < http://www.sbpcnet.org.br/site/noticias/mostra.php?id=1766>.
} 
O que se verifica de todo o exposto sobre as áreas de preservação permanente é que o novo Código embora tenha mantido o conceito e os objetivos das áreas de preservação permanente, em seus dispositivos introduziu diversas modificações que podem comprometer as áreas sensíveis extremamente necessárias para a manutenção dos serviços ecossistêmicos que o instituto busca resguardar.

Ao conceito de Reserva Legal foi acrescentada pelo novo código a função de assegurar o uso econômico dos recursos naturais de modo sustentável. Cipriano (2011) aduz neste sentido que:

\footnotetext{
Constata-se, portanto, que na nova definição a importância ecológica da reserva legal adquire menor relevo, pois seu papel na conservação e reabilitação dos processos ecológicos, conservação da biodiversidade, bem como no abrigo e na proteção de fauna silvestre e da flora nativa deixa de ser imprescindível para tornar-se meramente acessório. Assim, esse caráter de "auxiliaridade ambiental" impingido à RL acentua a predominância do aspecto econômico (consubstanciado na função atribuída de assegurar a exploração econômica sustentável dos recursos naturais) sobre o ecológico.
}

O dispositivo que trata da delimitação da área de reserva legal possuiu redação bastante similar ao do antigo Código Florestal, embora existam hipóteses que o novo Código Florestal permite a redução dos percentuais mínimos de reserva legal (80\% na floresta amazônica - 35\% do cerrado na Amazônia Legal - 20\% demais coberturas florestais).

Nos casos de imóveis rurais localizados na Amazônia Legal, em áreas de floresta, o Poder Público poderá reduzir a reserva legal de $80 \%$ para até 50\%, para fins de recomposição, quando o Município tiver mais de 50\% da área ocupada por unidades de conservação da natureza de domínio público e por terras indígenas homologadas.

Nos casos de imóveis rurais localizados na Amazônia Legal, em áreas de floresta, o Poder Público estadual poderá reduzir a reserva legal de $80 \%$ para até $50 \%$, ouvido o Conselho Estadual de Meio Ambiente, quando o Estado tiver Zoneamento Ecológico-Econômico aprovado e mais de $65 \%$ do seu território ocupado por unidades de conservação da natureza de domínio público, devidamente regularizadas, e por terras indígenas homologadas;

Nos casos de imóveis rurais localizados na Amazônia Legal, em áreas de floresta, o Poder Público federal poderá reduzir a reserva legal de $80 \%$ para até $50 \%$, quando indicado pelo Zoneamento Ecológico-Econômico estadual, exclusivamente para 
fins de regularização, mediante recomposição, regeneração ou compensação da Reserva Legal de imóveis com área rural consolidada, excluídas as áreas prioritárias para conservação da biodiversidade e dos recursos hídricos.

A possibilidade de redução da Reserva Legal é alvo críticas por parte dos cientistas, senão vejamos: Na Amazônia Legal, em função dos Zoneamentos Ecologico-Econômicos (ZEE) de cada Estado, abre- se a possibilidade de reduzir a RL de áreas florestadas de $80 \%$ para 50\%. Apesar de muitos Estados ainda não terem zoneamentos aprovados, pode-se prever que, sob pressão dos proprietários todos eles tenderão a sancionar tal redução percentual, tornando-se assim importantes indutores ou facilitadores do desmatamento em amplas áreas de toda a Amazônia. Essa alteração terá efeito especialmente impactante, pois deverá reduzir o patamar de cobertura florestal da Amazônia para níveis abaixo de 60\%, percentual hoje considerado nos estudos científicos realizados como um limiar crítico para a manutenção da conectividade (ou continuidade) física da floresta. Abaixo deste limiar, os ambientes tenderão a ser mais fragmentados, com fragmentos menores, mais isolados, e logo com maior risco de extinção de espécies e deterioração dos próprios fragmentos, além da perda de sua efetividade como ecossistemas funcionais ( JOLY, et. al. 2011, p.5).

A primeira mudança no que tange a localização da reserva legal refere-se a exclusão da possibilidade de órgãos municipais conveniados aprovarem a reserva legal. $\mathrm{O} \S 1^{\circ}$ do art. 14 do novo código prevê ainda após o protocolo da documentação exigida para análise da localização da área de Reserva Legal, fica vedada a imputação de sanção administrativa ao proprietário ou possuidor rural, inclusive restrição a direitos, em razão da não averbação da área de Reserva Legal.

Ao discriminar os estudos e critérios que devem ser levados em consideração para a definição da localização da área de Reserva legal, o art. 14 coloca três novidades em relação ao antigo código (i) a formação de corredores ecológicos com outras áreas protegidas; (ii) a ocorrência de áreas de maior importância para a conservação da biodiversidade; e (iii) a existência de áreas de maior fragilidade ambiental.

O novo Código Florestal passa a prever expressamente a não exigência da reserva legal para determinados empreendimentos: a) empreendimentos de abastecimento público de água e tratamento de esgoto; b) áreas adquiridas ou desapropriadas por detentor de concessão, permissão ou autorização para exploração de potencial de energia hidráulica, nas quais funcionem empreendimentos de geração de energia elétrica, subestações ou sejam instaladas linhas de transmissão e de distribuição 
de energia elétrica; c) áreas adquiridas ou desapropriadas com o objetivo de implantação e ampliação de capacidade de rodovias e ferrovias.

No tema da averbação da reserva legal a mudança no novo código é substantiva. A averbação da reserva legal tinha por objetivo garantir a publicidade, característica geral dos registros públicos, bem como, visava garantir a perenidade da destinação da área pelo atual e por futuros proprietários. No novo código a averbação no registro de imóveis é substituída pela inscrição no CAR mediante a apresentação de memorial descritivo e coordenadas geográficas, conforme ato do poder Executivo.

Observa-se, pois, que há uma fragilização do instituto, vez que se substitui a averbação, instituto que garante certa segurança jurídica para a inscrição no CAR, cadastro ambiental rural, que ainda deverá ser regulamentado por ato do chefe do poder executivo. No que concerne à posse a redação dos dispositivos é semelhante.

$\mathrm{O}$ primeiro ponto polêmico quanto à possibilidade de compensação da reserva legal revela a possibilidade do proprietário que detinha reserva legal inferior ao determinado pela lei até julho de 2008 poder regularizar sua situação sem ao menos fazer sua adesão ao PRA.

Outro ponto que chama a atenção é possibilidade de recomposição da reserva legal com espécies exóticas, no Código Antigo elas somente poderiam ser utilizadas como pioneiras, já no Novo Código além de poderem ser utilizadas na recomposição juntamente com frutíferas, o proprietário ainda pode explorá-las economicamente (art. $\left.66, \S 3^{\circ} ; 4^{\circ}\right)$. O Novo Código também prevê a possibilidade de compensação da reserva legal dentro do mesmo bioma, mesmo que em estados diferentes. Anteriormente a regra no máximo dentro da mesma bacia hidrográfica desde que no mesmo estado.

Neste ínterim importante salientar a opinião dos cientistas:

a proposta de novo CFB cria diversas novas possibilidades de compensação de $\mathrm{RL}$, na forma de compra de cotas de reserva ambiental, de arrendamento sob regime de servidão, ou de doação ao poder público de áreas dentro de Unidades de Conservação. O problema maior é que esta compensação poderá ser feita em qualquer localidade dentro do mesmo bioma. Isto significa, por exemplo, que um proprietário do interior de São Paulo, que deveria conservar uma RL de mata mesófila Semidecídua, pode compensar a destruição irregular desta RL comprando uma área de mata ombrófila densa da Serra do Mar, ou mesmo de uma área de mata em Pernambuco. Nos dois exemplos dados, as matas não são equivalentes, pois elas estão situadas em condições ambientais e climáticas distintas, possuindo assim vegetações e ecossistemas bastante diferentes e que não se equivalem. Esse novo dispositivo legal ignora que as florestas e demais 
formações vegetacionais brasileiras são heterogêneas, resultado de complexos processos biogeográficos, sendo esta justamente a razão para que estas áreas sejam reconhecidas internacionalmente pela sua alta biodiversidade. A maioria das espécies tem distribuição geográfica limitada dentro de cada bioma, seja em centros de endemismos ou zonas biogeográficas, seja em diferentes fisionomias. Áreas de compensação não adjacentes ou fora da mesma microbacia não se prestam a conservar espécies da região perdida (JOLY, et. al., 2011, p.6)

As compensações deveriam ser realizadas somente em áreas ecologicamente equivalentes, considerando não apenas as regiões de endemismo, mas também as diferenças de composição de espécies e estrutura dos ecossistemas que ocorrem dentro das subdivisões de cada grande bioma brasileiro. Mesmo assim, é importante notar que qualquer compensação de perda da RL em uma região realizada em outra área, não repõe os serviços ecossistêmicos que a RL perdida prestava na sua área original, nem impede a degradação ambiental progressiva que tal perda provoca. (JOLY, et. al., 2011, p.6).

Ao final, verifica-se que a disciplina de transição das explorações consolidadas em área de reserva legal é regulada pelos artigos 66, 67, 68 e 69 do novo Código Florestal, tendo sido tomado como marco legal divisor do regime jurídico o dia 23 de julho de 2008.

Para os proprietários e possuidores rurais que detinham, em 22 de julho de 2008, área de reserva legal em extensão inferior ao estabelecido no artigo 12 no novo Código ( $80 \%$, $35 \%$ ou $20 \%$, a depender da localização e do Bioma), poderão regularizar a sua situação, independentemente da adesão ao Programa de Regularização Ambiental, adotando as seguintes alternativas, isolada ou conjuntamente: I - recompor a Reserva Legal; II - permitir a regeneração natural da vegetação na área de Reserva Legal; III compensar a Reserva Legal.

A recomposição consiste no reflorestamento da reserva legal degradada, de acordo com os critérios definidos pelo órgão ambiental, permitindo o novo CFlo que haja o plantio intercalado de espécies nativas regionais e exóticas, em sistema agroflorestal, desde que a área recomposta com espécies exóticas não exceda a 50\% da área total a ser recuperada. Além disso, a recomposição deverá ser concluída em até 20 anos, abrangendo, a cada 2 dois anos, no mínimo 1/10 um décimo da área total necessária à sua complementação. 
Caso as condições naturais sejam permissivas, é possível que o proprietário ou possuidor nada faça para regularizar a sua reserva legal, bastando não impedir a regeneração natural da vegetação, consistindo em uma obrigação de não fazer.

No caso das propriedades rurais com até 04 módulos fiscais até 22 de julho de 2008 e que possuam um remanescente de vegetação nativa, existe um tratamento legal favorável, pois mesmo não possuindo os percentuais mínimos de reserva legal, não haverá necessidade da sua recomposição, visto que o artigo 67, do novo Código, admite que a reserva legal será constituída com a área ocupada com a vegetação nativa existente em 22 de julho de 2008, vedadas novas conversões para uso alternativo do solo.

\subsection{3) Conclusões e perspectivas para às áreas de preservação permanente e reserva legal}

A Constituição Federal de 1988 recepcionou a instituição das áreas de reserva legal como forma de garantir a execução dos objetivos constitucionais de proteção do meio ambiente. De fato, os próprios conceitos de reserva legal e de área de preservação permanente, deixam evidente o papel de tais instrumentos de proteção ambiental na efetivação dos desígnios constitucionais contidos no art. 225 da Carta da República.

A obrigação de manter áreas de preservação permanente e reserva legal recai sobre proprietários privados é decorrência do princípio social da propriedade e de sua dimensão ambiental.

As áreas de preservação permanente é um dos instrumentos fundamentais do Direito Ambiental, face à importância dos serviços ambientais por ela prestados, vez que além a proteção da biodiversidade provê a geração e manutenção da fertilidade dos solos, a proteção contra erosões, o controle dos ciclos hidrológicos locais e a manutenção do microclima.

Já a reserva legal surge com a necessidade de se buscar a proteção de áreas ambientalmente relevantes, limitando o pleno exercício do direito de propriedade.

A restrição e diminuição destas áreas pode representar a promoção de processos de uso e ocupação do solo que agravação a fragmentação de floretas nativas, os efeitos de borda sobre as áreas de remanescentes florestais, a depauperação da flora e fauna nativas, a supressão de vegetação em diferentes estágios sucessionais, a ruptura de corredores ecológicos. 
Lado outro, o fortalecimento e a defesa destes institutos são fundamentais para conservação da biodiversidade. Ademais a conjugação das áreas de preservação permanente e de reserva legal com unidades de conservação e instrumentos de incentivo positivo constitui estratégia fundamental para a gestão integrada da biodiversidade.

O Novo Código Florestal, lei 12.651 de 25 de maio de 2012, que apresenta como princípios em seu art. $1^{\circ}$, a afirmação do compromisso soberano do Brasil com a preservação das suas florestas e demais formas de vegetação nativa, da biodiversidade, do solo e dos recursos hídricos, e com a integridade do sistema climático, para o bemestar das gerações presentes e futuras; a consagração do compromisso do País com o modelo de desenvolvimento ecologicamente sustentável, que concilie o uso produtivo da terra e a contribuição de serviços coletivos das florestas e demais formas de vegetação nativa privadas; a ação governamental de proteção e uso sustentável de florestas, coordenada com a Política Nacional do Meio Ambiente, a Política Nacional de Recursos Hídricos, a Política Agrícola, o Sistema Nacional de Unidades de Conservação da Natureza, a Política de Gestão de Florestas Públicas, a Política Nacional sobre Mudança do Clima e a Política Nacional da Biodiversidade; criação e mobilização de incentivos jurídicos e econômicos para fomentar a preservação e a recuperação da vegetação nativa, e para promover o desenvolvimento de atividades produtivas sustentáveis, dentre outros, mas possui em seu bojo uma série de dispositivos intricados, que podem vir a colocar em cheque os princípios acima arrolados transformando-os apenas em uma legislação simbólica.

Em razão deste fato foram ajuizadas quatro ações diretas de inconstitucionalidade ADIs n 4901, 4902 e 4903, ajuizadas pela Procuradoria-Geral da República em 18 de janeiro de 2013, ADI n 4937, ajuizada pelo Partido Socialismo e Liberdade (PSOL) em 04.04.2013. As ações possuem como argumentos comuns a diminuição do padrão de proteção ambiental e até mesmo extinção de espaços territoriais especialmente protegidos e a afronta aos deveres fundamentais do poder público para garantia do direito ao meio ambiente ecologicamente equilibrado já que normas impugnadas do Novo Código FLorestal violariam o principio da vedação de retrocesso ambiental. Uma vez que de forma geral referidas normas estabeleceriam um padrão de proteção ambiental manifestamente inferior ao anteriormente existente. 


\section{3) Gestão Integrada da Biodiversidade}

\section{2) Histórico e Fundamento Científico}

Embora a implantação do Sistema Nacional de UCs e a delimitação de restrições de direito de propriedade constituam uma estratégia fundamental de conservação da natureza, tem-se questionado até que ponto as UCs e áreas isoladas, dissociadas de uma perspectiva mais abrangente da paisagem, são sustentáveis em longo prazo.

Está cada vez mais claro que não se pode pensar na gestão de reservas como se fossem ilhas de biodiversidade. Toda área protegida, solitariamente, estará fadada à perda progressiva de sua diversidade, à degradação do seu entorno, à incursão de espécies exóticas ou à proliferação de outras perturbações. Todo plano de manejo deve considerar a reserva legal, a sua zona tampão, e a manutenção das possibilidades de fluxos biológicos entre reservas vizinhas.

A gestão de Unidades de Conservação vem progressivamente passando de uma gestão de ilhas para uma gestão de redes de unidades, esta evolução fica clara quando se analisam os princípios de gestão de mosaicos de Unidades de Conservação, propostos Sistema Nacional de Unidades de Conservação (METZGER, CASSATI, 2006, p.6). Ademais a Lei n 9.985 de 2000, em seu artigo $5^{\circ}$, XIII dispõe que o SNUC deve buscar proteger grandes áreas por meio de um conjunto integrado de unidades de conservação de diferentes categorias, próximas ou contíguas, e suas respectivas zonas de amortecimento e corredores ecológicos, integrando as diferentes atividades de preservação da natureza, uso sustentável dos recursos naturais e restauração e recuperação dos ecossistemas.

Neste mesmo sentido alguns autores ao analisarem as deficiências no processo de criação de UCs, destacam o fato de que as unidades de conservação não estão integradas as políticas de desenvolvimento e uso da terra em nível regional e/ou local. O mesmo problema já foi apontado pelo Ministério do Meio Ambiente, ao afirmar que as UCs tornaram-se um arquipélago de parques e reservas isolados, frequentemente pressionados por todos os lados e inadequados para garantir, em longo prazo, a proteção das espécies de plantas e animais que contem (GANEM, 2011, p. 388).

Desta forma segundo Ganem (2011, p.390) "para garantir a perpetuação da diversidade biológica, a política de conservação deve levar em conta o contexto 
socioeconômico em que as unidades se inserem e propor medidas de gestão do entorno das unidades. Paisagens manejadas com múltiplos usos da terra podem permitir o movimento de populações da fauna e da flora por meio de 'ligações' entre hábitats”.

Essa abordagem alternativa revela uma transformação na forma de se pensar a conservação: passa-se a gestão de cenários amplos com o intuito de ligar as categorias de UCs e as áreas destinadas a conservação e a produção. Essa mudança de paradigma representa o que Miller (1997) citado por Ganem (2011, p.390) denomina de gestão biorregional, que busca manter o elo entre áreas virgens nucleares e entre estas e as respectivas zonas de transição. A estratégia de implantação envolve os donos das terras e visa estabelecer usos amistosos com a biodiversidade.

A necessidade de promover a conectividade entre os fragmentos de ecossistemas naturais encontra ainda sua base na Biologia da Conservação: os processos ecológicos necessitam de áreas extensas para se manterem. Populações da flora e da fauna isoladas são mais vulneráveis as pressões externas, sendo susceptíveis a extinção. A biologia da conservação é uma ciência multidisciplinar que foi desenvolvida como resposta à crise com a qual a diversidade biológica se confronta nos últimos tempos. A biologia da conservação possui dois objetivos: primeiro, entender os efeitos da atividade humana nas espécies, comunidades e ecossistemas e, segundo, desenvolver abordagens práticas para prevenir a extinção de espécies e se possível reintegrar as espécies ameaçadas ao seu ecossistema funcional (PRIMACK, RODRIGUES, 2001, p.5).

A biologia da conservação baseia-se em um número de premissas aceitas pela maioria dos biólogos conservacionistas, quais sejam: a diversidade de espécies é positiva, a extinção das espécies devido a ação do homem é negativa, a interação complexa das espécies em comunidades naturais é positiva, a evolução das espécies é positiva e a diversidade biológica tem valor em si mesma (PRIMACK, RODRIGUES, 2001, p.67).

Como dito anteriormente a fragmentação de habitat é o processo pelo qual uma grande e contínua área de habitat é tanto reduzida em sua área quanto dividida em fragmentos. Quando o habitat é destruído, fragmentos de habitat são deixados para trás. Esses fragmentos são frequentemente isolados uns dos outros, por uma paisagem altamente modificada, esta situação pode ser descrita pelo modelo de biogeografia de ilhas, com os fragmentos funcionando como ilhas de habitat em um " mar" inóspito dominado pelo homem (PRIMACK, RODRIGUES, 2001, p.95). 
Cerqueira et. al. (2003, p. 24) observam que a fragmentação dos hábitats é um fenômeno natural, em razão da heterogeneidade das condições físico-químicas do ambiente. "Os seres vivos encontram no mundo uma colcha de retalhos" em que os recursos para sua sobrevivência estão distribuídos desigualmente. O mundo natural é um mosaico. No entanto, o preocupante é a intensidade da fragmentação dos hábitats imposta pelo homem, capaz de acarretar a extinção de espécies e mesmo de ecossistemas inteiros (GANEM, 2011, p. 387).

Como salientado acima, referida fragmentação pode levar a perda das espécies que sobreviveram já que cria barreiras para o processo normal de dispersão, colonização e alimentação (PRIMACK, RODRIGUES, 2001, p.133). Ademais a fragmentação aumenta a possibilidade de invasão de espécies exóticas no ecossistema original. A invasão de espécies exóticas por sua vez pode aumentar a fragmentação através da competição, predação e introdução de doenças nas espécies nativas.

A fragmentação de habitat ainda aumenta drasticamente sua quantidade de borda. O microclima numa borda de fragmento é diferente daquele do interior da floresta. Alguns dos efeitos de borda mais importantes são o aumento do nível da luz, temperatura e vento. Uma vez que as espécies de plantas e de animais são normalmente adaptadas de forma precisa a certa temperatura, umidade e níveis de luz, essas mudanças eliminarão as espécies dos fragmentos de floresta (PRIMACK, RODRIGUES, 2001, p.100).

Afora o impacto que as atividades humanas têm sobre o fragmento, as áreas que rodeiam os remanescentes têm uma importância fundamental para dispersão das espécies nativas e para conexão das populações dos fragmentos.

Em razão dos fundamentos arrolados resta claro a necessidade de se pensar em instrumentos que fomentem a conectividade das áreas impedindo ou mesmo amenizando os efeitos da fragmentação de hábitats. É chegado o momento em que os instrumentos para conservação da biodiversidade sejam concebidos e executados de maneira integrada e coerente.

No Brasil, estão em implantação três instrumentos diretos de gestão integrada da biodiversidade: corredores, mosaicos e reservas da biosfera. 


\section{2) Corredores, Mosaicos e Reservas de Biosfera}

Arruda (2000) citado por Ganem (2005, p.6) afirma que a conservação da biodiversidade pode ser feita em várias escalas, dependendo da abordagem adotada. Assim, as estratégias podem ser em escala global (acordos internacionais); escala de biomas ou de ecorregiões (estudos de representatividade; definição de prioridades para conservação); escala de espécies (criação em cativeiro).

O termo corredor ecológico vem sendo utilizado em diferentes contextos, com definições e em escalas diversas no Brasil. Esse instrumento já estava previsto na legislação brasileira desde 1993, quando o Decreto $\mathrm{n}^{\circ}$ 750, dispunha sobre o corte, a exploração e a supressão de vegetação primária ou nos estágios avançado e médio de regeneração da Mata Atlântica, e dava outras providências, proibiu a exploração de vegetação que tinha por função formar corredores de remanescentes de vegetação primária ou em estágio avançado e médio de regeneração (GANEM, 2005, p.6).

Posteriormente, a Resolução do Conselho Nacional do Meio Ambiente (CONAMA) $\mathrm{n}^{\circ} 9$ de 1996, a partir do Decreto acima, estabeleceu em seu art. $1^{\circ}$ a seguinte definição de corredores de remanescentes de Mata Atlântica: corredor entre remanescentes caracteriza-se como sendo faixa de cobertura vegetal existente entre remanescentes de vegetação primária em estágio médio e avançado de regeneração, capaz de propiciar habitat ou servir de área de trânsito para a fauna residente nos remanescentes (GANEM, 2005, p.6).

Atualmente, o termo corredor ecológico é previsto no art. 25 da Lei $n^{\circ} 9.985$ de 2000 que institui o Sistema Nacional de Unidades de Conservação que o define como porções de ecossistemas naturais ou seminaturais, ligando UCs, que possibilitam entre elas o fluxo de genes e o movimento da biota, facilitando a dispersão de espécies e a recolonização de áreas degradadas, bem como a manutenção de populações que demandam para sua sobrevivência áreas com extensão maior do que aquela das unidades individuais art. $2^{\circ}$, XIX da mesma da lei (GANEM, 2011, p.391,392).

A Lei do SNUC ainda estabelece, entre as diretrizes do Sistema Nacional de Unidades de Conservação, proteger grandes áreas por meio de um conjunto integrado de UCs de diferentes categorias, próximas ou contíguas, e suas respectivas zonas de amortecimento e corredores ecológicos, integrando as diferentes atividades de preservação da natureza, uso sustentável dos recursos naturais e restauração e recuperação dos ecossistemas (art. $5^{\circ}$, XIII). 
Desta feita, verifica-se que os corredores ecológicos devem ser instituídos entre unidades de conservação, exceto áreas de proteção ambiental e reservas particulares do patrimônio natural. De acordo com o art. 11 do Decreto $n^{\circ} 4.340$, de 22 de agosto de 2002, que regulamenta a Lei do SNUC, o corredor ecológico deve ser reconhecido por portaria do MMA.

Ganem (2011, p. 392,393), aponta que conforme o conceito legal em vigor, o corredor ecológico abrange áreas de vegetação nativa ou de sistemas seminaturais manejados tendo em vista a manutenção da conectividade entre unidades de conservação. $\mathrm{O}$ conceito legal está vinculado às unidades de conservação, mas claramente restrito as áreas necessárias para interligá-las, sem as incluir. No âmbito desse conceito, foram criados dois corredores ecológicos: o corredor que une os Parques Nacionais da Serra da Capivara e o da Serra das Confusões, no estado do Piauí, por meio da Portaria MMA nº 76, de 11 de março de 2005, e que cria o Mosaico CapivaraConfusões, e o Corredor Ecológico da Caatinga, pela Portaria MMA n 131, de 4 de maio de 2006, nos estados de Pernambuco, Bahia e Sergipe que une diversas unidades de conservação ${ }^{21}$.

Todavia, o termo corredor também tem sido utilizado em uma abrangência maior a fim de proteger grandes parcelas dos biomas. Segundo Lima (2008) citado por Ganem (2011, p. 393) em 1992, José Márcio Ayres propôs ao MMA a implantação de sete corredores de biodiversidade no território nacional, dois dos quais foram selecionados para implantação: o Corredor Central da Amazônia (CCA) e o Corredor Central da Mata Atlântica (CCMA). Nesse Projeto, os corredores são definidos como grandes áreas que contêm ecossistemas florestais biologicamente prioritários para a conservação da diversidade biológica na Amazônia e na Mata Atlântica compostos por conjuntos de UCs, terras indígenas e áreas de interstício, de modo a prevenir ou reduzir a fragmentação das florestas existentes e permitir a conectividade entre áreas protegidas. (MMA,IBAMA, 2001, p. 9).

Referido documento define áreas de interstício como aquelas situadas entre as unidades de conservação e áreas indígenas, podendo pertencer ao domínio público ou

${ }^{21}$ Parque Nacional do Catimbau, Reserva Biológica de Serra Negra, Estação Ecológica do Raso da Catarina, Área de Proteção Ambiental Serra Branca/Raso da Catarina, Área de Relevante Interesse Ecológico Cocorobó, Parque Natural Municipal Lagoa do Frio, Reserva Particular do Patrimônio Natural Cantidiano Valqueiro Barros, Reserva Particular do Patrimônio Natural Reserva Ecológica Maurício Dantas, suas zonas de amortecimento, interstícios, e "áreas protegidas existentes ou aquelas a serem criadas" (art. $1^{\circ}$ ). A inclusão dessas áreas, além das UCs, extrapola o conceito de corredor ecológico expresso na Lei do SNUC. 
privado. Vislumbra-se, pois, que as demais áreas protegidas, tais como áreas de preservação permanente, reservas legais, reservas particulares do patrimônio natural estão inclusas neste conceito.

Prado et al. (2003) citados por Ganem (2005, p.8) afirmam que o corredor ecológico ou de biodiversidade é um mosaico de usos da terra que conectam fragmentos de floresta natural através da paisagem. A finalidade do corredor é facilitar o fluxo genético entre populações, aumentando a chance de sobrevivência a longo prazo das comunidades biológicas e de suas espécies.

Cases e Brackelaire (2007) citados por (GANEM, 2011, p.396) identificaram vários critérios para a definição dos limites de um corredor: físicos (como bacias hidrográficas ou unidades geomorfológicas); ecológicos; funcionais (fragmentação e representatividade de hábitats); culturais; político-administrativos; de gestão (presença de parceiros e sinergia com políticas públicas) ou temporais (prioridades e viabilidade a longo prazo). O IBAMA (2001) destaca os seguintes critérios ecológicos: diversidade de espécies e ecossistemas, riqueza de espécies endêmicas, grau de conectividade entre os remanescentes de vegetação nativa, integridade dos blocos de paisagem natural. Todos esses aspectos são fundamentais para conferir motivação e viabilidade ao corredor de biodiversidade.

No entanto, Ganem (2011, p. 398) aduz que a gestão do corredor deve visar, primordialmente, o levantamento das áreas de interesse para a conservação dos remanescentes de vegetação nativa, a restauração florestal e a manutenção/construção da conectividade de hábitats e, em seguida, a atuação do Poder Público em parceria direta com os proprietários dessas terras. Para que o corredor de biodiversidade se consolide, as parcerias institucionais devem ser instituídas de forma objetiva, tendo em vista o aumento da área conservada e o fomento a conectividade. A perda de objetividade nos trabalhos de articulação institucional pode levar ao desperdício de recursos e ao não cumprimento da meta de aumento efetivo da área conservada.

A mesma autora assinala as experiências de implantação de corredores de biodiversidade estão se repetindo, no Brasil. No entanto, esse instrumento ainda não conseguiu avançar da etapa de planejamento territorial para a etapa de constituição de uma política aplicada ao espaço territorial. Citando (LIMA, 2008, p. 15) afirma que o autor defende a continuidade da gestão de "macroespaços territoriais" e a multiplicação dessa experiência no país, com dotação orçamentária própria aplicando os princípios da biologia da conservação ao conceito de corredores de biodiversidade, estabelecendo 
formas ágeis de repasse de recursos afim de promover ganhos de escala com a restauração.

O corredor de biodiversidade representa assim uma estratégia de conservação que abrange um processo permanente de negociação de interesses quanto a gestão dos recursos naturais, da coordenação entre as diferentes esferas de governo, da descentralização de atribuições e da articulação de entidades públicas e privadas. $O$ esquema necessita da construção de acordos entre órgãos governamentais, proprietários de terra, empreendedores, organizações não governamentais e população local.

Para fomentar a conectividade nos corredores de biodiversidade, as UCs e demais áreas devem desenvolver um projeto de planejamento, no qual devem estar previstas estratégias diversificadas de proteção da biodiversidade. Nas áreas de interstício, os usos do solo favoráveis à manutenção da diversidade biológica podem ser estimulados por meio de instrumentos de incentivo positivo. $\mathrm{O}$ aspecto central destes últimos como veremos no próximo capítulo é o seu caráter indutor de comportamentos desejados pela política ambiental.

Concluindo, é importante fazer a distinção conceitual entre corredores ecológicos que tem definição legal (Lei no 9.985 de 2000) e referem-se às ligações entre unidades de conservação e entre os projetos de abrangência regional, correspondentes a corredores de biodiversidade que não foram definidos em lei e que abrangem as unidades de conservação, suas zonas de amortecimento e corredores ecológicos, terras indígenas, reservas legais, áreas de preservação permanente e outras áreas privadas e públicas com usos compatíveis com a conservação da biodiversidade. Com a finalidade de evitar possíveis conflitos sugere-se o uso do termo corredor ecológico apenas para os casos que enquadrarem na definição legal, aplicando-se lado outro as expressões corredor de biodiversidade ou corredor biorregional aos projetos de abrangência regional (GANEM, 2011, p. 394).

O termo mosaico encontra definição no art. 26 da Lei do SNUC e engloba o conjunto de unidades de várias categorias, próximas, justapostas ou sobrepostas, assim como outras áreas protegidas, públicas ou privadas. A gestão do mosaico, segundo a Lei do SNUC, deverá integrar as diversas unidades, com seus objetivos distintos, e estas com a população residente e/ou do entorno, e deverá promover o desenvolvimento sustentável no contexto regional.

O mosaico deve ser reconhecido por um ato do Ministério do Meio Ambiente, a pedido dos órgãos gestores das respectivas unidades, e contar com conselho consultivo, 
a ser presidido por chefe de uma das unidades de conservação integradas ao mosaico e que deverá, entre outras atribuições, propor diretrizes e ações visando compatibilizar as atividades desenvolvidas em cada unidade.

Os mosaicos, assim como os corredores e as reservas da biosfera, são mencionados como estratégia de gestão integrada no Decreto n ${ }^{\circ} 5.758$, de 13 de abril de 2006, que institui o Plano Estratégico Nacional de Áreas Protegidas (PNAP), nos itens 3.2, I, b, e 3.3, II, d (GANEM, 2011, p.397).

Ressalte-se que a iniciativa de instituição do mosaico cabe aos gestores das unidades de conservação, e não ao MMA. Este apenas reconhece o mosaico, por portaria conforme já fora dito anteriormente. Para o reconhecimento dos mosaicos, o MMA exige a seguinte documentação: justificativa e comprovação de que houve participação dos proponentes com a comunidade e com os demais órgãos envolvidos, para esclarecimento da proposta e organização de futuras ações conjuntas; inscrição das unidades de conservação no Cadastro Nacional de Unidades de Conservação (CNUC), no sítio eletrônico do MMA; carta de adesão de cada órgão gestor das unidades que integram o mosaico, de todas as esferas da Federação; e minuta de portaria, com a lista das unidades de conservação que integrarão o mosaico e a representação do futuro conselho de mosaico (GANEM, 2011, p.401).

Conforme o art. 10 do Decreto $\mathrm{n}^{\mathrm{o}} 4.340$ de 2002, compete ao conselho consultivo do mosaico: propor diretrizes e ações para compatibilizar, integrar e otimizar a relação com a população residente na área do mosaico, bem como as atividades desenvolvidas em cada UC (em relação aos usos na fronteira entre unidades, ao acesso as unidades, a fiscalização, ao monitoramento e avaliação dos planos de manejo, a pesquisa científica e a alocação de recursos advindos da compensação referente ao licenciamento ambiental de empreendimentos com significativo impacto ambiental); manifestar-se sobre propostas de solução para a sobreposição de unidades; e manifestarse, quando provocado por órgão executor, por conselho de unidade de conservação ou por outro órgão do Sistema Nacional do Meio Ambiente, sobre assunto de interesse para a gestão do mosaico (GANEM, 2011, p.401,402).

Até o ano de 2010 o Ministério do Meio Ambiente reconheceu seis mosaicos: Mosaico Capivara- Confusões, situado no estado do Piauí, reconhecido pela portaria MMA n 76, de 11 de março de 2005; Mosaico do litoral de São Paulo e Paraná, nos estados de São Paulo e Paraná, reconhecido pela Portaria MMA n ${ }^{\circ} 150$, de 8 de março de 2006; Mosaico Bocaina, situado nos estados do Rio de Janeiro e São Paulo, 
reconhecido pela Portaria MMA n 349 , de 11 de dezembro de 2006; Mosaico Mata Atlântica Central Fluminense, situado no estado do Rio de janeiro, reconhecido pela Portaria MMA n ${ }^{\circ}$ 350, de 11 de dezembro de 2006; Mosaico Mantiqueira, situado nos estados do Rio de Janeiro, São Paulo e Minas Gerais, reconhecido pela Portaria MMA n 351 de 11 de dezembro de 2006 e Mosaico Sertão Veredas - Peruaçu, situado no estado de Minas Gerais, reconhecido pela portaria MMA n ${ }^{\circ} 128$ de 24 de abril de 2009.

Os mosaicos podem ter distintos tamanhos e desenhos, ocupando um ou vários municípios e estados. Seu contorno depende a princípio, da disposição das unidades de conservação que o compõem. Considerando a teoria da biologia da conservação é necessário para a demarcação de um mosaico que as conexões entre os fragmentos sejam fomentadas, tornando maior a área de circulação das espécies e por consequência o fluxo gênico. Antes, contudo é preciso que o corpo técnico esteja ciente das funções esperadas de cada conexão entre os fragmentos. É de acordo com o foco de conservação é que os mosaicos e corredores devem ser definidos (MACIEL, 2007, p.116).

O meio físico e biofísico no qual se localiza o mosaico pode em alguns casos impor restrições aos planejadores, assim sendo, o formato e o tamanho do mosaico vão depender da conciliação de variáveis como: espécies foco da conservação, funções dos corredores, escala de tempo trabalhada, capacidade de gestão, e limitações impostas pelos instrumentos de ordenamento territorial (MACIEL, 2007, p.116).

Maciel (2007, p.116) assinala que eventuais conexões entre os fragmentos também devem ser planejadas com base nas teorias da Ecologia de Paisagens, que considera os diversos tipos de solo. As áreas de interstícios são frequentemente ocupadas por terras privadas, e geralmente possuem Áreas de Preservação Permanente e reservas Legais que devem ser incorporadas à estratégia de conservação da biodiversidade na área do mosaico.

Neste sentido existiriam três formas de integrar as terras privadas numa estratégia de conservação, a primeira mais dispendiosa e complicada seria a desapropriação para a transformação em unidade de conservação, a segunda seria o incentivo à transformação de parte da propriedade em uma RPPN e terceira que não a exclui as demais, mas que é mais natural é inclusão das Áreas de Preservação Permanente e Reservas Legais na estratégia de conservação, como dito acima (MACIEL, 2007, p.118) .

A fim de garantir que a gestão dos mosaicos funcione com vistas a conservação da biodiversidade é preciso que se faça uso dos instrumentos legais já existentes e que 
as lacunas porventura existentes na legislação sejam preenchidas pelo sistema de gestão a ser utilizado. Ou seja, como regra geral pode-se dizer que os mosaicos de unidades de conservação devem ser planejados com um foco de conservação definido, utilizando-se de instrumentos legais já existentes, levando em conta as restrições impostas pelas ferramentas de gestão territoriais existentes (planos diretores zoneamento econômico ecológico), suprindo as lacunas com instrumentos de gestão específicos para cada caso concreto, construídos com a participação da sociedade e de entes governamentais. Desta forma o mosaico estará em tese sustentado legal e institucionalmente (MACIEL, 2007, p.119-121).

Por fim, as reservas da biosfera, assim como os mosaicos, também estão previstas na Lei, art. 41 do SNUC. Diz a lei: A reserva da biosfera é um modelo, adotado internacionalmente, de gestão integrada, participativa e sustentável dos recursos naturais, com os objetivos básicos de preservação da diversidade biológica, o desenvolvimento de atividades de pesquisa, o monitoramento ambiental, a educação ambiental, o desenvolvimento sustentável e a melhoria da qualidade de vida das populações.

Assim sendo, a reserva da biosfera é uma estratégia de gestão integrada da biodiversidade, formada por áreas-núcleo, zonas de amortecimento e zonas de transição geridas de forma participativa. A reserva é gerida por um conselho deliberativo.

Entretanto, o maior diferencial das reservas da biosfera, em relação aos mosaicos e corredores de biodiversidade, é o seu reconhecimento pela Organização das Nações Unidas para a Educação, a Ciência e a Cultura (UNESCO). As reservas da biosfera fazem parte do Programa O Homem e a Biosfera (Manand Biosphere - MAB), criado em 1971 pela UNESCO. O conceito foi firmado em 1974 e refere-se a iniciativas de gestão territorial tendo em vista "harmonizar a convivência entre o homem e seu espaço vital". O objetivo dessas reservas é proteger a diversidade biológica em biorregiões estratégicas do planeta, conciliando a conservação com o desenvolvimento, e promover o conhecimento científico sobre essas áreas. Atualmente, existe uma rede de 553 reservas da biosfera, em 107 países $^{22}$. O zoneamento das reservas da biosfera abrange áreas-núcleo, zona de amortecimento e zona de transição.

\footnotetext{
${ }^{22}$ LINO, Clayton. Reservas da biosfera, sítios do patrimônio natural, sítios Ramsar e outras designações internacionais para conservação da biodiversidade. In: SEMINÁRIO ANO INTERNACIONAL DA BIODIVERSIDADE, 2010, Brasília. [Anais...] Brasília: Câmara dos Deputados, 2010.
} 
Para atingir seus objetivos as reservas de biosfera foram organizadas de modo a conter três zonas distintas: áreas núcleo, zona de amortecimento e zona de transição. Somente a área núcleo exige proteção legal por meio de unidade de conservação. $\mathrm{O}$ esquema de zoneamento é adaptado às características geográficas locais. Essa flexibilidade é um dos pontos principais do conceito de reserva biosfera, vez que facilita a integração entre as áreas protegidas e demais paisagens.

Cada reserva tem seu próprio sistema administrativo de modo a atingir sseus objetivos. Sua administração precisa ser aberta e envolver as comunidades locais para melhor responder as pressões locais que afetariam ecologicamente a área. A UNESCO não exige qualquer mudança nas leis ou nos termos de propriedade das terras. Entretanto, é necessário estabelecer um mecanismo de governança para planejar e coordenar as atividades da reserva de biosfera.

\section{3) Gestão integrada da biodiversidade: conclusões e desafios}

Corredores, mosaicos e reservas da biosfera representam estratégias de conservação da biodiversidade fundamentadas na gestão integrada do território e tem como objetivo promover a conectividade entre áreas nativas em bom estado de conservação. Algumas iniciativas estão sendo implantadas no Brasil, a fim de promover a conservação em larga escala, de parcelas dos biomas brasileiros.

Os mosaicos, reservas da biosfera e corredores ecológicos encontram previsão legal na Lei $\mathrm{n}^{\circ} 9.985$ de 2000, ao passo que os corredores de biodiversidade e projetos de maior amplitude regional ainda não possuem regime jurídico definido em lei. Faz-se necessário discutir a necessidade de dar amparo legal a esses projetos. Todas as iniciativas acima incluem blocos de unidades de conservação, mas os corredores de biodiversidade e as reservas da biosfera vão muito além dos seus limites.

A gestão integrada da biodiversidade representa um avanço na maneira de se pensar e implantar políticas públicas de conservação da biodiversidade, vez que possuem como finalidade resolver ou diminuir a contradição existente entre as áreas protegidas - destinadas à preservação/conservação - e seu entorno (áreas intersticiais) este submetido, na maioria dos casos, a políticas desenvolvimentistas e predatórias.

A novidade está, sobretudo, no reconhecimento por parte do Poder Público e de parcela das organizações ambientalistas, de que as unidades de conservação isoladas 
não garantem proteção à biodiversidade. Portanto, percebe se mudança de um modelo de conservação centralizado e focado em áreas isoladas para outro, descentralizado e focado na gestão integrada do território, mais coerente com os princípios do desenvolvimento sustentável.

A implantação desta gestão requer a aplicação efetiva dos diversos instrumentos da política ambiental nas áreas de interstício, quais sejam o zoneamento, a avaliação de impacto ambiental, o licenciamento, o monitoramento e a fiscalização, visando à redução e à prevenção de impactos ambientais negativos.

Da mesma forma, não se pode prescindir do envolvimento das comunidades locais e da análise de inserção de instrumentos econômicos, como forma de incentivo à conservação de áreas naturais. Sem o auxílio destas, dificilmente a gestão integrada conseguirá atingir seu objetivo.

Observa-se assim que os projetos e programas não estão normalmente centralizados nas ações de planejamento territorial e por isso não conseguem mudar os padrões de uso do solo nas áreas de interstício entre as unidades . Deve-se salientar, também, que mudanças nesse padrão dependem, especialmente, do envolvimento dos agricultores na manutenção da vegetação nativa, sobretudo nas regiões e biomas sujeitos a altas taxas de desmatamento e fragmentação.

Nos corredores de biodiversidade, nas reservas da biosfera e no entorno das unidades de conservação, dos mosaicos, ações específicas deveriam ser implantadas para esse setor, com estímulos a conservação em terras privadas.

Por fim, percebe-se que, apesar dos avanços acima apontados, relativos à gestão integrada do território, os corredores ecológicos ainda estão inseridos numa política setorial, de conservação da biodiversidade. A ênfase ainda está focada em áreas protegidas, as quais, já se sabe, não vingam por si mesmas. Entende-se que a verdadeira mudança de paradigma em relação à proteção da biodiversidade e demais recursos naturais somente ocorrerá quando houver integração de fato de instituições e de políticas públicas voltadas para o desenvolvimento regional de forma sustentável. 


\section{4) Instrumentos de incentivo posito: pagamento por serviços ambientais}

\section{1) Instrumentos de Incentivo Positivo}

Os instrumentos de incentivo positivo são criados por normas jurídicas que propõem inovações dentro da estrutura comportamento/sanção. "Trata-se do fato de imputarem a um determinado comportamento uma sanção positiva, que pode ter o caráter de prêmio, retribuição ou mesmo de facilitação da conduta desejada" (NUSDEO, 2010, p.227).

O direito pautou-se pela ideia de sancionador das condutas humanas, agindo sempre na condição de protetor das situações já ocorridas, com aplicações de sanções como resposta ao ilícito cometido. Não obstante, esta maneira de agir tem demonstrado que apenas sua ação sancionatória não é suficiente para conter as condutas negativas apresentadas pela sociedade, como a crescente degradação ambiental vivenciada.

A partir das mudanças de comportamento social que vêm ocorrendo nos últimos tempos exige-se do Estado condutas apropriadas para acompanhá-las, passa-se a valorizar e incentivar a conduta social que determina a forma positiva de agir, buscando o equilíbrio das ações humanas para a manutenção do convívio harmônico de toda a sociedade.

O direito contém sanções negativas e positivas, mas sempre com prevalência das negativas como sinônimas do cumprimento das normas. Por este motivo, a sociedade contemporânea, que vive em um estado permanente de transformações em razão dos avanços conquistados, já não se satisfaz com as sanções jurídicas codificadas como forma eficiente para a solução dos problemas. Essas constantes mudanças sociais exigem que novos instrumentos sejam criados para estimular e promover as condutas desejáveis, ou seja, aquelas que trazem benefícios à sociedade, principalmente no âmbito do direito ambiental (CHIQUITO, 2012 p.109).

Esses novos instrumentos jurídicos de premiação e incentivos, que atualmente estão surgindo como uma nova solução para os problemas ambientais, já estavam previstos na doutrina há algum tempo. Altmann (2008, p.60) com base Benthan explicita que já no século XIX acenava-se para as sanções premiais como um instrumento jurídico que poderia ser de grande valia já para a sociedade moderna. No 
entanto, o estado liberal era o estado mínimo, que se limitava a punir as condutas indesejadas, furtando-se de intervir em relação às condutas desejadas.

Norberto Bobbio, estudioso das sanções positivas, considerava o Direito como um sistema, no qual o Estado, a partir de meados do século XX, não só se restringia a coibir ou admitir condutas, mas que igualmente passou a recompensar e estimular condutas sociais. Referido jurista entendia por "função promocional":

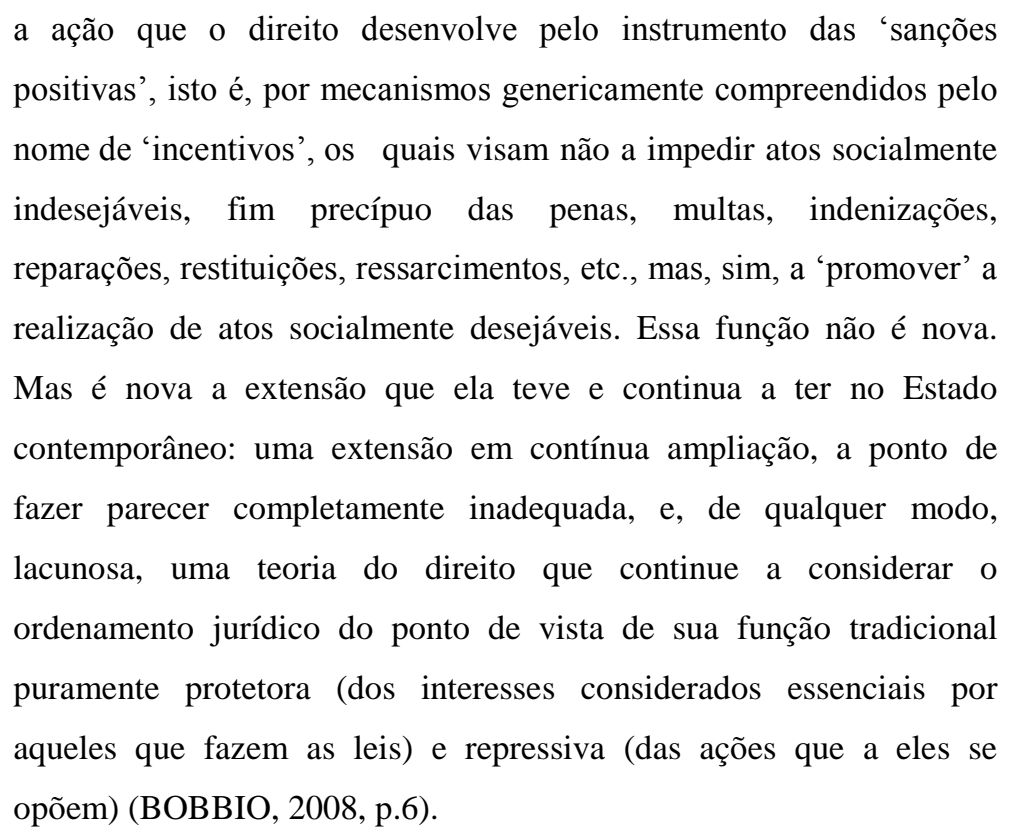

Bobbio (2008, p.17) assinala que a diferença entre as leis de incentivo e a maioria das normas sancionatórias é que aquelas empregam a técnica do encorajamento, promovendo comportamentos desejados, enquanto estas empregam a técnica do desencorajamento, ao reprimir comportamentos indesejados.

Desta forma a função promocional do direito se efetiva pelos expedientes do prêmio e do incentivo, adotando-se os incentivos para facilitar o exercício de uma determinada função econômica e os prêmios para oferecer uma satisfação a quem já tenha realizado uma determinada atividade (BOBBIO, 2008, p.71, 72).

Neste mesmo sentido, a tendência ao uso de mecanismos de caráter econômico para a gestão ambiental apoia-se em princípios como o poluidor-pagador, usuáriopagador e protetor-recebedor. Este último é o que fundamenta o pagamento pelos serviços ambientais.

Em que pese a sua importância para o bem estar humano, esses serviços até pouco tempo atrás não eram considerados pela economia e nem previstos expressa ou implicitamente pelo Direito. Ocorre que com a crise ambiental, pode-se verificar a diminuição acentuada do fluxo destes serviços. Em razão deste declínio os serviços 
ambientais passam a influenciar a economia afim de que ao uso indireto destes serviços sejam agregados valores.

Os Instrumentos de incentivo positivo, no viés do direito econômico são aqueles que atuam diretamente nos custos de produção e consumo dos agentes cujas atividades estejam inseridas nos objetivos da política em questão. Os exemplos são os tributos em geral e os preços públicos, que podem ser criados, majorados ou reduzidos, assim como a criação de mecanismos de mercado para transações no âmbito dos limites legais de utilização dos recursos naturais, como no caso dos serviços ambientais.

Destarte para a economia ambiental o conceito de serviços ambientais relacionase com o conceito de externalidades positivas, assim como o de poluição foi vinculado à ideia de externalidades negativas. O reconhecimento da importância dos serviços ambientais através de sua valoração e remuneração, portanto, significa a internalização das externalidades positivas (ALTAMANN, 2010, p.275). De acordo com Stefano Pagiola et.al (2005) citados por Altmann (2010, p.275) “as externalidades são os custos ou benefícios gerados a terceiros e que não são levados em conta nos preços de mercado."

Nesse mesmo sentido as lições de Ana Maria Nusdeo:

Nos sistemas econômicos capitalistas, os mercados se tornaram a instituição central de organização da economia. Os preços são usados pelos mercados para comunicar as necessidades, desejos e limites da sociedade e dirigir as decisões econômicas para que resultem na provisão de tais necessidades e desejos pelo menor custo. Entretanto, os preços de mercado não refletem adequadamente o valor de vários bens e serviços ambientais e, portanto, eles não são providos ou prestados no montante desejado pela sociedade [...] A falha de mercado ocorre quando o mercado não aloca os recursos sociais de modo a gerar o maior bem estar social possível. ${ }^{23}$

Nota-se do exposto acima, que a economia tradicional preocupa-se prioritariamente com aquilo que possui utilidade aos homens, por isso a análise da economia ambiental se direciona para a valoração de recursos ambientais que anteriormente eram considerados livres (NUSDEO, 2010, p. 57). Contudo, esta visão sofre várias críticas, uma delas advindas da economia ecológica, que busca ampliar o espectro de valoração dos recursos ambientais, vez que considera a escassez física dos mesmos.

\footnotetext{
${ }^{23}$ NUSDEO, Ana Maria. O papel dos mercados e dos direitos de propriedade na proteção ambiental. Disponível em:<http://www.law.yale.edu/documents/pedf/sela/Nusdeo_porthuguese
} 
Os parágrafos acima permitem inferir que os estudos relativos aos instrumentos econômicos e a técnica promocional necessitam de uma abordagem interdisciplinar. É preciso que o Direito dialogue com metodologia da econômica, como análise de custo benefício e o comportamento racional dos agentes. Dialogar com essa metodologia, por outro lado, torna conveniente a compreensão de como as linhas econômicas trabalham essa relação com o meio ambiente, o que será feito brevemente no item abaixo.

Diante dessas premissas estudadas e ressaltadas acima, pode-se afirmar que chegou a hora do nosso Direito Ambiental passar a adotar as técnicas do incentivo positivo, instituto promocional do direito, estimulando as condutas dos protetores do meio ambiente nacional, que são onerados sem qualquer novo estímulo ou incentivo para ação de proteção e controle da degradação.

Como exemplo deste tipo de legislação pode-se citar o ICMS ecológico. O Imposto sobre Circulação de Mercadorias e Prestação de Serviços (ICMS) é um imposto estadual, que constitui uma importante fonte de recursos para os governos locais, uma vez que a Constituição Federal estipula que $25 \%$ do total do ICMS arrecadado pelo estado sejam distribuídos aos municípios (art. 158). Além disso, a Constituição prevê que a distribuição de três quartos do valor a ser alocado considere o valor agregado em cada município. O estado pode estabelecer critérios de distribuição para o um quarto restante.

Tradicionalmente, para distribuição desse um quarto dos recursos, os governos estaduais utilizam critérios que consideram o tamanho da população, a área geográfica e a produção primária. Com essas regras, municípios que detêm, por exemplo, áreas ambientalmente protegidas ou de proteção de mananciais argumentam que são prejudicados, uma vez que as restrições de uso da terra restringem o desenvolvimento de atividades produtivas. Note-se que esses municípios em regra perdem no recebimento da parcela do ICMS que depende do valor agregado (JURAS, ARAÚJO 2008).

A fim de modificar esse quadro, o estado do Paraná instituiu, em 1991, sistema de distribuição do ICMS que inclui critério ecológico aplicado a 5\% do total de recursos distribuído aos municípios (Lei Complementar $n^{\circ} 59$, de $1^{\circ}$ de outubro de 1991 , do estado do Paraná). Desses 5\%, metade vai para municípios com mananciais de abastecimento de água e metade para aqueles com unidades de conservação, terras indígenas, faxinais e reservas florestais legais. Muitos estados tem tomado como experiência o Paraná, e editado normas sobre a distribuição dos $25 \%$ dos recursos 
recebidos do ICMS que levam em consideração parâmetros de proteção ao meio ambiente. São exemplos São Paulo (1993), Minas Gerais (1995), Rondônia (1996), Rio Grande do Sul (1998), Pernambuco (2000), Mato Grosso do Sul (2001), Mato Grosso (2001), Rio de Janeiro (2007) e Piauí (2008) (JURAS, 2009,p.32).

Entre as exigências do ICMS ecológico, definidos nas leis estaduais, estão a conservação de espaços protegidos, iniciativas de saneamento e outras caracterizadas no conceito mais amplo do desenvolvimento sustentável. Os resultados positivos são aparentes: o aumento da superfície de áreas protegidas, no Paraná, foi de 142,82\% até 1999, e em Minas Gerais, de 48\%, entre 1991 e 1998 (JURAS, 2009, p.8).

Outras iniciativas destinadas a ampliar os incentivos concedidos ao meio ambiente tramitam no Congresso Nacional, entre as quais se destacam três grupos: as que preveem regras semelhantes às aplicadas no ICMS ecológico à repartição dos tributos federais aos Estados (FPE) e aos Municípios (FPM); uma prevê deduções do Imposto sobre a Renda para aplicação em projetos ambientais (IR ecológico) (JURAS, 2010, p.62) e vários projetos que tratam do pagamento por serviços ambientais, estes últimos serão tratados de maneira pormenorizada nos tópicos a seguir, senão vejamos.

\section{2) Serviços Ambientais: Introdução, Definição e Caracterização}

Quando se examina os serviços ambientais, serviços ecossistêmicos para alguns autores, e sua importância para a sustentabilidade, a caracterização dos mesmos é o ponto de partida (VEIGA, 2008, p.8). Segundo um dos primeiros trabalhos sobre este tema, serviços ambientais podem ser definidos como sendo os serviços prestados pelos ecossistemas naturais e as espécies que os compõem, na sustentação e preenchimento das condições para a permanência da vida humana na Terra (DAYLE,1997 citado por VEIGA, 2008, p.8). Ou, de acordo Robert Constanza e co-autores (1997, p.254) serviços ambientais são "fluxos de materiais, energia e informação de estoques de capital natural que são combinados ao capital de serviços humanos para produzir bem estar aos seres humanos."

Mas o que este conceito traz a tona é a importância que estes serviços tem para a manutenção e continuidade da vida na terra. Um dos principais esforços de levantamento de informações realizado até o momento sobre este tema, o Millenium 
Ecosystem Assessment ${ }^{24}$, trabalho realizado entre 2001 e 2005, por solicitação das Nações Unidas, teve como seu principal escopo aferir os impactos das mudanças que estão ocorrendo nos ecossistemas em relação ao bem estar das sociedades humanas. Este estudo conceituou os serviços ecossistêmicos como os benefícios que as pessoas e as sociedades humanas obtém dos ecossistemas, e os dividiu em quatro grupos, a saber: a) Serviços de provisão: alimentos, água, madeira e fibra; b) Serviços de regulação: manutenção do clima, prevenção de enchentes, controle de doenças, ciclagem de lixo e outros dejetos e manutenção da qualidade da água; c) Serviços culturais: benefícios recreativos, estéticos e espirituais; d) Serviços de apoio: formação de solo, fotossíntese e ciclagem de nutrientes (VEIGA, 2008, p.8).

A discussão propriamente dita sobre o pagamento dos serviços realizados pelos ecossistemas inicia-se a partir de alguns pontos importantes. O primeiro deles diz respeito ao conhecimento pela sociedade da deterioração constante destes serviços, baseado na informação repassada por cientistas de todas as áreas do conhecimento ligadas às ciências naturais, assim como pelas inúmeras Organizações Não Governamentais ambientais em todo o mundo que desempenham de maneira importante o papel de conscientizar a população para os problemas ambientais (VEIGA, 2011).

Outro aspecto que chama a atenção é a percepção de que por um longo período, a sociedade vem recebendo estes serviços sem pagar nada por eles, sem considerá-los na contabilidade das ações empreendidas.

Para alguns autores, o desenvolvimento do conceito de Pagamentos por Serviços Ambientais ${ }^{25}$, se origina no debate sobre a eficiência das abordagens tradicionais para a conservação dos ecossistemas, comumente associadas ao desenvolvimento rural, que foram bastante privilegiadas, particularmente no mundo tropical, nos países em desenvolvimento, nas décadas recentes, particularmente depois da Conferência - Rio 92. Os dois enfoques mais importantes, os "Projetos Integrados de Conservação e Desenvolvimento - PICD" e o "Manejo Florestal Sustentável - MFS" sofreram diversas críticas quanto à eficácia de suas ações em relação à conservação, basicamente por conta de dúvidas em relação à possibilidade de combinação destas duas

\footnotetext{
${ }^{24}$ MA. Millenium Ecosystem Assessment. Ecosystems and Human Well-being: Synthesis. Washington DC. Disponível em português em: http://www.maweb.org/documents/document.446.aspx.pdf: IslandPress, 2005.

${ }^{25}$ WUNDER, Sven. Payments for environmental services: some nuts and bolts. Center for internacional forestry research - CIFOR.(2005). Disponível em: http://www.cifor.org/publications/pdf_files/OccPapers/OP-42.pdf
} 
grandes agendas, a conservação da natureza e a redução de pobreza, assim como a forma indireta de abordar os problemas ambientais (VEIGA, 2008, p.10).

$\mathrm{O}$ autor citado emprega cinco critérios para definir quais seriam os pagamentos por serviços ambientais "puros": a) uma transação voluntária onde; b) um serviço ambiental (ou um uso de solo que claramente seja capaz de gerar aquele serviço) bem definido; c) é comprado por (pelo menos um) comprador de serviço ambiental; d) de (pelo menos um) vendedor de serviço ambiental; e) se e apenas se, o vendedor de fato entregar o serviço. ${ }^{26}$

Dos critérios supra se extrai alguns pontos importantes. O primeiro diz respeito a voluntariedade da participação, predicado do instrumento econômico, aversa às medidas de comando e controle. Esta característica possuiu como pressuposto a possibilidade do provedor ter outras opções de uso da terra. O segundo ponto, é a necessidade da clara definição do serviço ambiental em pauta. Neste caso, quanto menor a certeza em relação ao serviço entregue, maior a possibilidade de questionamento em relação às vantagens de pagar por elas. Igualmente fica claro que esta se falando de uma transferência de recursos entre um comprador e um vendedor; recursos estes que somente serão pagos, se existir a provisão dos serviços. (VEIGA, 2008, p.10).

Fora dos PSA's conceituados como "puros”, outros autores tais como LandellMills e Porras (2002) admitem um conjunto muito mais amplo de arranjos, também como PSA's. No caso deste trabalho, os pagamentos por serviços ambientais foram tidos como aqueles em que havia algum tipo de pagamento cuja intenção seria a promoção de serviços ambientais (VEIGA, 2008, p.10).

De acordo com Powell e White (2001), citados por Veiga (2008, p.11), os pagamentos por serviços ambientais também podem ser classificados em três categorias de acordo com o nível de intervenção governamental:

A primeira delas, onde o grau de intervenção governamental é menor, é aquela em que preponderam as combinações privadas entre os produtores de serviços e os beneficiários e ocorre predominantemente quando há a constatação por parte dos usuários que o custo de tratamento ou a redução da renda advinda da perda do serviço ultrapassa o pagamento pelo serviço ambiental. É o caso no qual fica claro para o

\footnotetext{
${ }^{26}$ WUNDER, Sven. Payments for environmental services: some nuts and bolts. Center for internacional forestry research - CIFOR(2005). Disponível em: http://www.cifor.org/publications/pdf_files/OccPapers/OP-42.pdf
} 
usuário, a vantagem do enfoque ecossistêmico ao invés da approach tradicional, de tratamento ou de reparo. Está fundamentada em transações intensas entre beneficiários e provedores dos serviços e a priori dispensa novos arranjos legais e regulatórios. É a que mais se aproxima do mercado "puro" proposto por Wunder (VEIGA, 2008, p.11).

A segunda categoria seria aquela onde prevalecem os mecanismos de permuta entre os agentes, geralmente usados a partir da definição pela autoridade reguladora de certo padrão a ser obtido por meio de transação entre os atores. Na realidade, seria outra forma de se fazer referência às licenças comercializáveis. Depende de um forte sistema de regulação e de um efetivo sistema de monitoramento (VEIGA, 2008, p.11).

Ao final, a última categoria sugerida seria aquela que enquadra os pagamentos realizados pelo setor público, assim considerado quando algum nível de Governo ou uma instituição pública (não necessariamente estatal) paga pelo serviço ambiental. Os recursos para estas negociações provêm de diferentes fontes, entre elas, orçamentos gerais de governos em seus diversos níveis e taxas de usuários. Os pagamentos podem ser destinados a provedores privados ou entidades públicas administradoras de recursos naturais. $\mathrm{O}$ fato de serem esquemas públicos não afasta a negociação. Pelo contrário, transações acuradas entre poderes públicos municipais, estaduais, empresas e outros stakeholders são importantes para o desenho de mecanismos como estes. Um bom exemplo seria a gestão de bacias hidrográficas, no caso brasileiro. Geralmente, necessita de alterações no aparato regulador (VEIGA, 2008, p.11).

Neste trabalho, utilizar-se-á o conceito de pagamento por serviços ambientais mais abrangente, englobando todas as categorias acima descritas por Powell e White e Landell-Mills e Porras. Para iniciarmos a reflexão teórica sobre o desenvolvimento dos pagamentos por serviços ambientais, a primeira questão a ser colocada é quais são as contribuições de cada escola econômica para o tema.

\section{3) Contribuições das escolas econômicas}

Fundamentada na teoria geral de sistemas, matemáticas não-lineares, termodinâmica de não-equilíbrio e da economia enquanto ciência da vida, a economia ecológica revela a necessidade de uma visão holística e transdisciplinar no estudo dos sistemas ecológicos e econômicos, pois, de acordo com Cavalcanti (2004, p.155) "são sistemas vivos complexos e adaptativos, que necessitam ser estudados como sistemas 
integrados em coevolução para que possam ser adequadamente compreendidos, trabalhados e desenvolvidos".

Sob a ótica da sustentabilidade como finalidade da economia ecológica, Daly (2004) relaciona algumas de suas diretrizes: deter os níveis de consumo ora praticados através de taxações da exploração dos recursos naturais; fazer compensações financeiras reduzindo o imposto de renda dos mais desprovidos em face da elevação do rendimento público; explorar os recursos não-renováveis proporcionalmente à criação de substitutos renováveis, dentre outras (SOUZA, et.al. 2010, p.8).

Martínez-Alier (1998, p.268) citado por Souza et. al.(2010, p.8) coloca:

O que é economia ecológica? É uma economia que usa os recursos renováveis (água, pesca, lenha e madeira, produção agrícola) com um ritmo que não exceda sua taxa de renovação, e que usa os recursos esgotáveis (petróleo, por exemplo) com um ritmo não superior ao de sua substituição por recursos renováveis (energia fotovoltaica, por exemplo). Uma economia ecológica conserva, assim, a diversidade biológica, tanto silvestre quanto agrícola. [...] é também uma economia que gera resíduos apenas na quantidade que o ecossistema pode assimilar ou reciclar.

Atenta para relação entre os sistemas econômicos e os sistemas ecológicos que os amparam e os contém, a economia ecológica sinaliza para a importância de uma escala sustentável, ou seja, a existência de um estoque de capital natural que seja capaz de manter as funções ecossistêmicas básicas, assim como o abastecimento de matériasprimas e a capacidade de absorção dos resíduos gerados pelas atividades econômicas ao longo do tempo. É neste contexto que o crescimento econômico que ultrapasse o ponto onde os custos ecológicos sejam maiores que os benefícios econômicos é ineficiente e extrapola a escala desejável. Ou seja, os limites ao crescimento baseados na carência dos recursos naturais são autênticos e não fundamentalmente superáveis através do avanço da tecnologia. A escala sustentável é aquela que se amolda de maneira progressiva às inovações tecnológicas, de modo que a capacidade de suporte não diminua com o tempo (VEIGA, 2008, p.12) (MAY, 1995).

A repartição alude para divisão relativa dos fluxos de recursos entre os distintos atores da sociedade, abarcando as futuras gerações, sendo a equidade na partição dos recursos uma questão central para a economia ecológica. Nesta temática, já direcionando para um dos aspectos fundamentais dos PSA, uma distribuição justa seria aquela, onde os que ultrapassaram a escala desejável ou que se beneficiaram das 
restaurações das funções ecossistêmicas são os mesmos que irão pagar por isto (VEIGA, 2008, p.12).

Embora e economia ecológica não tenha conseguido se desvencilhar da necessidade de uma expressão econômica para expressar a importância dos recursos ambientais, seus adeptos tem buscado desenvolver metodologias que incorporem outros fatores ao espectro de valoração, tem surgido assim as valorações multicriterias.

Para a concepção econômico-ecológica, os bens e serviços Ecossistêmicos possuem mais de uma dimensão de valor, além da econômica (dimensões ecológica e socioambiental), que exigem metodologias específicas para sua valoração, não redutíveis à métrica monetária (ROMEIRO, MAIA, 2011, p.18).

Deste modo a avaliação ecossistêmica está no núcleo do método científico da abordagem econômico-ecológica, que se considera uma abordagem inerentemente interdisciplinar por oposição à abordagem historicamente monodisciplinar da economia neoclássica (ROMEIRO, MAIA, 2011, p.19)

O apreço a parâmetros mais realistas sobre o comportamento e capacidade humana na avaliação de recursos naturais e a abertura da "caixa preta da fabricação de bens e serviços ecossistêmicos" pela abordagem econômico ecológica convergem para proposições metodológicas de valoração bem mais complexas, em que se busca levar em conta a natureza complexa dos ecossistemas e os distintos valores que lhes são associados, bem como os riscos de perdas irreversíveis potencialmente catastróficas de estruturas e funções ecossistêmicas (ROMEIRO, MAIA, 2011, p.21).

Lado outro, no que tange à economia neoclássica o fato dos serviços ambientais terem se mantido fora do mercado é explicado por duas principais razões derivadas da Teoria das Externalidades.

“A Teoria das Externalidades chama de efeitos externos à economia quando há um descolamento entre os custos ou benefícios privados e os custos ou benefícios sociais de uma ação empreendida por um indivíduo" (VEIGA, 2008, p.16).

Sob este ponto de vista, a solução neoclássica revela a necessidade das políticas ambientais internalizarem estes efeitos externos, ou seja, igualarem ao custo privado do ator econômico, o custo social da ação empreendida por ele, abrangendo nos seus custos este valor, que pelo menos em tese, recompensaria os custos sociais da ação empreendida. Segundo esta vertente teórica, elaborada pelo economista A.C.Pigou em trabalho publicado em 1920, estas diferenças entre os custos privados e sociais 
poderiam ser corrigidas através de taxas e subsídios, de forma a alterar os custos privados até que eles se equiparem aos custos sociais (VEIGA, 2008, p.16).

Esta concepção teórica foi uma políticas ambientais europeias no século passado, integrada aos instrumentos de comando e controle usualmente utilizados. Este enfoque recebe muitas críticas, em razão da dificuldade de se contabilizar corretamente o custo social ou da função de dano do agente poluidor, fazendo com que as taxas sejam praticadas muito mais em função de critérios políticos ou técnicos e não econômicos (VEIGA, 2000). Outra crítica sobre sua aplicação até o momento e que se refere especificamente aos serviços ambientais é que ela foi usada preponderantemente através do princípio do poluidor-pagador, ou seja, com o objetivo básico de punir poluidores e trazê-los mais próximo do ótimo social, mas praticamente nunca através do princípio protetor-recebedor, ou seja, remunerando aqueles que protegendo o ambiente gerem benefícios sociais não incorporados ao mercado.

Por sua vez, a contribuição da economia institucional dá-se na medida em que chama atenção dos formuladores de políticas públicas para a necessidade de compreender que os arranjos que serão criados para o desenvolvimento dos pagamentos por serviços ambientais se relacionarão com as instituições formais e informais existentes nas comunidades e localidades que os programas se desenvolverão. A noção de instituição relaciona-se com as normas, hábitos e consensos relacionados à vida econômica e social.

Em resumo, com base nas lições de Ana Maria de Oliveira Nusdeo, a iniciativa de lançar luz sobre a dimensão e valor dos ecossistemas coube aos economistas ecológicos. Esta corrente busca alargar a abordagem econômica dos recursos naturais não apenas para os apropriáveis e que tem valor de troca mas para os aspectos ecossistêmicos que dão suporte ao uso dos recursos. Ademais a maior proximidade da economia ecológica à ciência da ecologia permite que se compreenda melhor a dinâmica dos ecossistemas, sua capacidade de resiliência e como as políticas ambientais podem ser construídas com estas informações. Observa-se, contudo que ao inserir os serviços dentro de uma análise econômica, subjazem as dificuldades de esse estabelecer critérios de valoração, nesta feita a economia ecológica tem trabalhado em técnicas que conjuguem valores ecológicos, econômicos e sociais, ou seja, em avaliações multicriteriais.

Ainda que o tema da remuneração pelos serviços ambientais se relacione com questões sociais que transcendem a análise limitada da economia neoclássica, a 
apresentação dos serviços ambientais como externalidades contribui para fundamentação de seu pagamento.

Por fim, análises institucionalistas permitem a compreensão da necessidade de ajustar os programas de pagamento por serviços ambientais à instituições formais e informais de cada localidade e a fomentar a participação de diversos agentes na construção destes arranjos.

\section{4) 0 que é necessário para o pagamento por serviços ambientais}

Seguindo a definição de Wunder, propõe-se que, ao elaborar um sistema de PSA, sejam considerados alguns componentes: a transação, o serviço ambiental (ou uso da terra capaz de prover o serviço), o comprador, o provedor e a condicionalidade. Adicionalmente, quando o PSA for um sistema mediado por governos, pode ser necessário estabelecer um marco legal. São diversos os fatores que definem se um projeto de PSA terá êxito ou não (SEEHUSEN, PREM, 2011, p.45).

Primeiramente, é preciso pesquisar em que medida o instrumento de PSA é mais apropriado do que outros para alcançar os objetivos ambientais desejados. Como levantam Pagiola e Platais (2007) citados por Seehusen, Prem (2011, p.45,46), “é preciso considerar que o escopo para o uso de PSA é restrito a um limitado número de problemas, em que os ecossistemas são mal manejados". Outro fator importante está ligado aos custos de transação do instrumento. É aconselhável utilizar o PSA como opção de gestão, se os benefícios gerados pelo instrumento (a melhora no provimento dos serviços ambientais) forem maiores que seus custos de implantação (custos de administração do mecanismo, das atividades em campo, de conscientização e articulação, etc.). Se este não for o caso, há a indicação para se verifique se existem opções de gestão mais custo-efetivas para se lidar com o problema ambiental (SEEHUSEN, PREM, 2011, p.46).

Finalmente, para que um PSA tenha êxito, seja eficaz e sustentável, é cogente o trabalho dedicado e constante para gerar espaços de participação interinstitucionais, incorporando a sociedade civil. É preciso trabalhar a conscientização, o diálogo e a educação ambiental, bem como fomentar capacidades nos temas relacionados (PERU MINAM, 2010 apud (SEEHUSEN, PREM, 2011, p.46). 
Não há uma receita única para se conceber um sistema de PSA e sempre é preciso adaptar a estratégia de intervenção às realidades locais (PERU MINAM, 2010 (SEEHUSEN, PREM, 2011, p.46).

No entanto, identificam-se muitas dificuldades por parte de instituições interessadas em ter um panorama sobre os pontos principais que envolvem um PSA. (SEEHUSEN, PREM, 2011, p.46). Neste contexto, como resultado da sistematização de lições aprendidas de uma experiência piloto conduzida no Peru, são propostos abaixo alguns passos e questões orientadoras para apoiarem o processo de desenvolvimento de um sistema de PSA dentro da estratégia de conservação, recuperação e uso sustentável dos recursos naturais em questão. Segundo esta proposta, o processo de desenvolvimento de PSA é dividido em tem três fases: de diagnóstico, desenho e implementação (PERU MINAM, 2010 apud SEEHUSEN, PREM, 2011, p.46).

Durante a fase de diagnóstico, pretende-se confrontar as condições atuais e desejadas e as tendências que se notam no uso da terra e no manejo dos ecossistemas, identificando os fatores críticos. Os resultados técnicos são apresentados aos atores, para empoderá-los sobre o processo no curto, médio e longo prazos (SEEHUSEN, PREM, 2011, p.46) .

Esta fase é dividida em três passos. O primeiro abarca a caracterização do ecossistema, a identificação dos serviços ambientais e a definição do problema ambiental. Para a caracterização, é necessário recolher informações sobre a área, usos da terra, serviços ambientais relevantes e fatores que estão influenciando o seu provimento, entre outros. Esse passo é fundamental para definir a importância do uso do PSA em uma determinada área para a sociedade (SEEHUSEN, PREM, 2011, p.46).

O seguinte trata-se da análise dos atores abrangidos (compradores e provedores de serviços ambientais) e da conjuntura econômica da região. É preciso angariar as seguintes informações: atividades humanas (tipo e localização); análise socioeconômica dos atores (incluindo o enfoque de gênero); e sistemas de manejo da terra e a sua relação com o fluxo dos serviços ambientais. Dependendo do interesse dos atores locais em aprovisionar os serviços ambientais ou da existência de demanda potencial, pode-se verificar em alguns casos que, a partir deste passo, a opção de implantar um PSA não é viável devido a conflitos, falta de capacidade institucional, falta de disposição a pagar, etc. (PERU MINAM, 2010 apud SEEHUSEN, PREM, 2011, p.47).

Depois, no terceiro passo, é preciso identificar as alternativas de manejo, valoração econômica e instrumentos financeiros. As informações necessárias são: 
informação biofísica para priorizar as áreas a conservar e/ou recuperar; e, identificação/priorização das medidas de proteção, conservação/uso sustentável, alternativas econômicas e cálculo de rentabilidade.

Como saldo desses três passos, deve-se procurar, a partir dos resultados obtidos, a análise da viabilidade da implementação do PSA, sopesando aspectos técnicos,

financeiros, institucionais, legais, culturais e políticos. É preciso também analisar as possíveis fontes de financiamento e os instrumentos financeiros existentes, explorar alternativas (SEEHUSEN, PREM, 2011, p.47).

Acessar a complementaridade do PSA com outros instrumentos e políticas é extremamente relevante também.

Se a análise de viabilidade sugerir que o PSA é uma estratégia conveniente para se adotar no contexto em questão, dá-se seguinte a próxima fase: desenho do esquema. Neste, os pagadores pelos serviços ambientais e instrumento financeiro que será usado, serão identificados. Ademais, deve-se definir o arranjo institucional e os aspectos de governança, que incluem a estrutura organizacional na gestão do mecanismo e na condução das atividades em campo, acordos e contratos, sistema de monitoramento etc. Finalmente, a terceira fase trata da implementação do sistema. Ela engloba a execução, o monitoramento e a avaliação (gestão adaptativa) (SEEHUSEN, PREM, 2011, p.47).

\section{5) Pagamentos por serviços ambientais para conservação da biodiversidade}

A biodiversidade é responsável pela manutenção da integridade e da dinâmica intrínseca dos ecossistemas naturais, é fundamental para a regulação do clima, para o provimento e regulação da qualidade e quantidade da água, para a produção de alimentos, cosméticos e medicamentos. Adicionalmente, a biodiversidade tem elementos que trazem consigo valores estéticos, espirituais e morais. Todos esses benefícios da biodiversidade são muito valiosos para a sociedade como um todo e são conhecidos como serviços ambientais.

A perda de biodiversidade afeta negativamente, e de forma imediata, o provimento destes serviços. Como exemplos tradicionais pode-se citar o impacto 
econômico da queda na produtividade de setores agrícolas devido à diminuição ou extinção de polinizadores ou de predadores naturais que controlam as pragas. Além disso, a manutenção da variabilidade genética, através da conservação e manejo de variedades selvagens pode proporcionar a resistência de culturas agrícolas a pragas ou a novas condições ambientais. A conservação dos habitats naturais e da diversidade de espécies que os compõem também preserva um acervo bioquímico e genético com potencial de uso e de descobertas para cura de diversas doenças, bem como de inspiração para inovações tecnológicas (SEEHUSEN et. al. 2011, p. 185).

Sopesando a situação de vulnerabilidade que se encontram vários ecossistemas, ações de proteção de áreas naturais, recuperação e regeneração natural, estabelecimento de corredores ecológicos e combate a espécies invasoras também devem ser valorizadas, por sua importância em garantir o provimento de serviços ambientais relacionados à biodiversidade.

Ademais, são também importantes para a proteção da biodiversidade as atividades produtivas sustentáveis, como sistemas produtivos agrobiodiversos e sistemas de manejo dos recursos naturais. Os sistemas agrobiodiversos geram externalidades positivas para a sociedade ao proteger a biodiversidade e garantir serviços a ela relacionados, esses benefícios geralmente não se concretizam em benefícios econômicos àqueles que as adotam, reduzindo o interesse na sua adoção. Mecanismos que permitam a internalização dos ganhos relativos às externalidades positivas geradas por práticas sustentáveis podem influenciar positivamente na competividade dessas atividades (SEEHUSEN et. al. 2011, p.185).

Destaca-se ainda a existência de uma grave carência de incentivos e subsídios financeiros e fiscais para atividades de produção sustentável. Opondo-se aos incentivos históricos providos para atividades econômicas extremamente danosas ao meio ambiente, como destruição de florestas para formação de pastos para agropecuária e monoculturas com uso intensivo de agrotóxico (YOUNG, 2003).

Nesse contexto os mecanismos de pagamentos por serviços ambientais para a proteção da biodiversidade, como alternativa para apoiar iniciativas de proteção, restauração, manejo e uso sustentável da biodiversidade, que garantam o provimento destes serviços ambientais à sociedade apontam como um caminho.

No mundo, existem múltiplos sistemas de pagamentos para a proteção da biodiversidade, tanto maduros quanto nascentes. Existem iniciativas de compra de habitat de alto valor, pagamentos pelo acesso à biodiversidade (espécies ou habitats) e 
ao conhecimento tradicional relacionado, pagamento por práticas de gestão e conservação da biodiversidade, assim como comercialização de cotas de conservação da biodiversidade sob tetos estabelecidos por regulamentações (cap and trade) e apoio a negócios de conservação da biodiversidade (Forest Trends; e Grupo Katoomba, 2008) (SEEHUSEN et. al. 2011, p. 196).

Mas os sistemas de PSA-Biodiversidade ainda enfrentam diversos desafios em sua concepção e implementação, que vão desde dificuldades de se estabelecer o que será monitorado até o de se determinar como será comprovada a adicionalidade das atividades. No entanto, um dos maiores desafios é encontrar os pagadores para os serviços ambientais (SEEHUSEN et. al. 2011, p.198).

Ilustrando a dificuldade acima um estudo realizado na Mata Atlântica, aferiu que o número de iniciativas de programas de pagamento por serviços ambientais relacionados à conservação da biodiversidade é inferior as demais iniciativas de pagamento por serviços ambientais, direcionados por exemplo para serviços ambientais hidrológicos e captura de carbono. Apenas cinco iniciativas levantadas focaram na biodiversidade (SEEHUSEN et. al. 2011, p.200).

$\mathrm{Na}$ pesquisa conduzida no estudo acima foram identificados apenas dois projetos de pagamento para a proteção da biodiversidade induzidos por interesses voluntários na Mata Atlântica. Sistemas voluntários surgem por motivos éticos, filantrópicos e até por interesses privados para a geração de lucro e para o consumo (Becca et al., 2010 APUD SEEHUSEN et. al. 2011 p.200).

Os programas de PSA para a conservação da biodiversidade surgem também por meio de programas de pagamentos mediados, em geral, por governos. Neste caso, governos ou outras organizações atuam como comprador ou pagador ao comprar áreas para conservação ou ao criar programas de pagamento para atividades que mantenham a biodiversidade (Becca et al., 2010). Na Mata Atlântica, já há leis e programas quem preveem o PSA por serviços de proteção da biodiversidade, como a Lei 17.727/2008 do estado de Minas Gerais e a Lei 8.995/2009, do estado do Espírito Santo (SEEHUSEN et. al. 2011, p.202).

Ainda no que tange ao pagamento por serviços ambientais mediados por governos um programa que demonstrou aspectos interessantes na articulação de instrumentos de comando e controle com pagamento por serviços ambientais relacionados à biodiversidade foi o PROMATA, projeto de proteção da Mata Atlântica em Minas Gerais. 
De acordo com o levantamento da cobertura florestal realizado pela Universidade Federal de Lavras, sob os auspícios da Secretaria Estadual de Meio Ambiente e Desenvolvimento Sustentável - SEMAD e do Instituto Estadual de Florestas de Minas Gerais - IEF em 2007, o Estado possuía apenas 23,4\% de cobertura florestal do bioma, que originalmente cobria cerca da metade do território mineiro.A devastação resultou na diminuição em $82 \%$ da fauna original do Estado, sendo $60 \%$ associada à Mata Atlântica (SEMA, Relatório Final PROMATA, p.15)

Coordenado pela Secretaria de Meio Ambiente e Desenvolvimento Sustentável de Minas Gerais (SEMAD) e executado pelo Instituto Estadual de Florestas (IEF), o PROMATA resultou de um acordo com a Cooperação Financeira Brasil-Alemanha.O programa esta baseado em cinco estratégias (SEMA, Relatório Final PROMATA, p.21).

A primeira se refere ao fortalecimento das unidades de conservação. Neste aspecto o PROMATA trabalhou em 15 unidades de conservação, das quais 13 estaduais e 2 federais, com um total de 566.615 hectares de matas preservadas, além das Reservas Particulares do Patrimônio Natural. Das 102 RPPNs mineiras, que totalizam 64.408 hectares protegidos, 7.012 hectares (77 unidades) se encontram em áreas de Mata Atlântica (SEMA, Relatório Final PROMATA, p.24).

Entre as ações idealizadas para este componente está a elaboração de Planos Manejo, que procuraram enfatizar os aspectos gerenciais, com o intuito de melhor atender à administração das unidades. Outro mecanismo importante foi o Diagnóstico Participativo em Unidades de Conservação - DIPUC, que conseguiu envolver os funcionários na implantação de melhorias nos parques. Junto a isso, soma-se a implantação dos Conselhos Consultivos, visando ampliar a participação da comunidade no processo de gestão dos parques e na adoção de práticas sustentáveis em suas áreas de entorno e de conectividade (SEMA, Relatório Final PROMATA, p.25).

A segunda estratégia estava voltada para o monitoramento e fiscalização na prática, o PROMATA agiu no fortalecimento das bases materiais e como facilitador nos processos de aprimoramento técnico dos profissionais do IEF, para uma atuação planejada, monitorada e avaliada em seus resultados. Melhor aparelhamento e capacitação contribuíram com o surgimento de uma abordagem integrada das ações, entre o Instituto, a SEMAD, a Polícia Militar Ambiental, o Corpo de Bombeiros e o Ministério Público (SEMA, Relatório Final PROMATA, p.25,26).

O terceiro componente trata da prevenção e combate aos incêndios florestais, foi criado um sistema de um sistema de prevenção e combate aos incêndios florestais, 
denominado Força-Tarefa/Previncêndio, resultado de parcerias entre o IEFF e outros órgãos responsáveis pela questão (SEMA, Relatório Final PROMATA, p.26).

A quarta estratégia aborda o desenvolvimento sustentável no entorno das unidades de conservação e áreas de conectividade, tendo como objetivos o incentivo a recomposição e a regeneração da floresta e a promoção da conectividade entre os remanescentes de Mata Atlântica no entorno das Unidades de Conservação, através da instituição de um incentivo financeiro para os agricultores engajados, como pagamento pelos serviços ambientais por eles prestados ao recuperar a floresta em suas propriedades. Estudos especialmente realizados indicaram as áreas com maior potencial de conectividade e as modalidades de intervenção apropriadas (SEMA, Relatório Final PROMATA, p.27,28).

De acordo com o relatório final do PROMATA a aplicação pura e simples da legislação ambiental, sem uma contrapartida de compensações aos habitantes do entorno das UCs, muitas vezes leva os vizinhos a considerar esta unidade um estorvo aos seus interesses.

Neste sentido foi que dentro do PROMATA desenvolveu-se um projeto-piloto com as comunidades próximas aos Parques Estaduais do Rio Doce, do Itacolomi, da Serra do Brigadeiro e da Serra do Papagaio, onde se procurou aperfeiçoar a sistemática de recuperação da mata nativa. O trabalho foi feito com apoio dos agricultores e buscou aumentar a conectividade entre fragmentos florestais de origem nativa, formando corredores de biodiversidade. Entre 2004 e 2008, foram recuperados, de acordo com_os dados do relatório final, cerca de 6 mil hectares de floresta. $O$ foco desta estratégia era trabalhar na zona de influência das UCs, para aumentar a vegetação nas imediações dos parques e enriquecer a biodiversidade (SEMA, Relatório Final PROMATA, p.63).

Este pagamento por serviço ambiental beneficiou 300 agricultores de 30 municípios mineiros, entre 2004 e 2008. Cada produtor recebeu de $\mathrm{R} \$ 140$ a $\mathrm{R} \$ 300$ por ano, por hectare recuperado, dependendo da modalidade de intervenção realizada nas suas terras. O pagamento foi feito por um período de três anos. Além dos incentivos financeiros, os agricultores beneficiados continuaram a receber gratuitamente as mudas, os insumos e a assistência aos plantios, prestada pelos técnicos do IEF e das instituições parceiras(SEMA, Relatório Final PROMATA, p.68).

Esta estratégia do PROMATA posteriormente deu origem ao programa de pagamento por serviços ambientais Bolsa Verde que possui como eixos a manutenção e recuperação da vegetação nativa no estado de Minas Gerais. 
A quinta estratégia cingiu-se à coordenação, monitoria e avaliação do programa.

Transpondo do plano teórico a análise dos componentes necessários para que um programa de PSA funcione bem para o PROMATA tem-se que o programa deu um passo importante para a complementaridade dos instrumentos de política pública.

A primeira etapa foi o diagnóstico tanto em relação à situação da mata Atlântica quanto das unidades de conservação. A partir dos dados lançados no relatório final do programa infere-se a situação de debilidade do bioma no estado de Minas Gerais. A primeira estratégia demonstrou que as unidades precisavam ser melhor administradas , por isso, investiu-se em planos de manejo que englobassem aspectos gerenciais.

O desenho do programa conferiu destaque para as ações de várias instituições a partir da criação do diagnóstico participativo em unidades de conservação e da implementação dos Conselhos.

Os dados do relatório indicam que foram realizados estudos específicos sobre as áreas com maior potencial de conectividade e sobre as modalidades de intervenção apropriadas. O programa de PSA foi direcionado para estas áreas.

Neste aspecto é possível verificar a adequação do PSA para a situação em que ele era realmente necessário, vislumbra-se que o que se buscou foi o menor custo de transação.

O programa de PSA não era suficiente para sanar todo o problema, mas era necessário para um dos objetivos do programa, a conectividade das áreas.

A valorização dos agricultores que residem nos entorno das unidades como agentes de conservação fomenta a participação destes nos conselhos, fortalecendo os espaços interinstitucionais. Ainda em relação a este aspecto ações de capacitação foram desenvolvidas para auxiliar no monitoramento e na fiscalização.

Os resultados do programa em termos de recuperação de áreas revelam que o saldo do programa foi positivo. Como principais pontos negativos têm-se o tempo de duração do programa, apenas 3 anos, este lapso temporal curto pode impedir que os resultados positivos permaneçam, estimulando os proprietários a ter outros tipos de uso de terra.

Era preciso pensar em estratégias para a continuidade do benefício. Não foram encontrados dados sistematizados que indicassem que os beneficiários do PROMATA passaram a ser do Bolsa Verde.

Outro aspecto passível de crítica é sobre a forma de cálculo do benefício, na bibliografia analisada não constam informações sobre esta metodologia. 
Os pagamentos diretos aos proprietários sem a necessidade de intermediários só pôde ser feita depois que a lei do Bolsa Verde foi editada, o que revela uma falha do programa.

Embora a legislação geral sobre os PSA's seja necessária e a expansão do número de beneficiários também, salienta-se a importância de programas mais específicos como o PROMATA para atender a realidades que também são diferenciadas. Com um objetivo específico é mais fácil avaliar o alcance do mesmo.

O programa acima demonstrou que o manejo adequado da biodiversidade requerer o uso de instrumentos de política pública, seja na forma de unidades de conservação e demais instrumentos de comando e controle, bem como, a necessidade de apoio às atividades econômicas sustentáveis. Neste contexto, os mecanismos de pagamento por serviços ambientais surgem como uma ferramenta complementar para promover atividades de conservação, manejo e uso sustentável dos recursos naturais.

Isto posto, pôde-se verificar que ainda existem muitos fatores que limitam a difusão de sistemas de PSA-Biodiversidade impedindo que eles alcancem resultados mais expressivos para a conservação da biodiversidade e melhoria da qualidade de vida das populações que contribuem para a sua conservação e uso sustentável.

O interesse em sistemas de pagamentos por serviços ambientais de proteção da biodiversidade ainda são limitados. Isto foi evidenciado pelo estudo realizado na Mata Atlântica . Isso provavelmente está relacionado às características de bens públicos quase puros dos serviços da biodiversidade. Ou seja, a falta dos serviços ambientais advindos da proteção da biodiversidade afeta muito indiretamente aqueles que se beneficiam dos serviços em contraste com o caso da água, por exemplo.

Além disso, embora seja não tão difícil saber quais são os tipos de usos da terra mais adequados para a conservação da biodiversidade, ainda é complexo calcular efetivamente qual a contribuição exata de cada um deles ao provimento de serviços ambientais. Desta forma um dos maiores desafios dos PSA-Biodiversidade é a dificuldade de definir o que deve ser monitorado e consequentemente como comprovar o benefício ambiental das atividades adotadas por sistema de PSA específico. Este desafio técnico está relacionado à variabilidade e heterogeneidade intrínseca dos sistemas ecológicos (SEEHUSEN et. al. 2011). Neste sentido faz-se necessário apoiar e desenvolver avaliações multicriteriais. 
Ademais, devem ser estimuladas as iniciativas que analisam as consequências para a biodiversidade de certos usos da terra que podem ser também alternativas econômicas para comunidades rurais.

No que tange ao monitoramento observa-se que ainda há a necessidade de aperfeiçoamento das técnicas, mas o barateamento da tecnologia de geoprocesamento (como imagens de satélite, fotografias aéreas e sistemas de informação geográfica), indica que o monitoramento remoto de serviços ambientais a partir de alvos da biodiversidade pode ser uma área promissora em um futuro próximo (SEEHUSEN et. al. 2011,p.).

A vista de todos estes aspectos conclui-se ainda há poucas políticas públicas visando implementar especificamente o pagamento por serviços ambientais para a biodiversidade. O desenvolvimento de políticas públicas municipais, estaduais e federais poderá alavancar a implantação de projetos que visem o pagamento por serviços ambientais no Brasil, permitindo grande impulso para a preservação da biodiversidade brasileira. Entretanto, é importante ressaltar que esses sistemas não devem ser vistos como substitutos às políticas ambientais de comando e controle, mas sim como mecanismos complementares de estímulo à conservação da biodiversidade, neste sentido o programa PROMATA oferece um horizonte de como estes instrumentos podem ser articulados afim de evitar a fragmentação de habitats e estimular a conservação da biodiversidade, através do desenvolvimento de um mix de políticas. 


\section{Conclusão}

O Brasil tem procurado criar um sistema jurídico capaz de implementar políticas públicas que assegurem a manutenção de sua biodiversidade e seu uso sustentável, ou genericamente, conservar seus recursos naturais.

A Constituição de Federal de 1988, alinhada com a evolução do direito constitucional comparado registrada nas ultimas décadas, consagrou, em capítulo próprio (art. 225), o direito ao ambiente ecologicamente equilibrado como autêntico direito fundamental da pessoa humana. A partir de tal inovação normativa, estabeleceuse - além da recepção da já expressiva legislação brasileira voltada a tutela ambiental todo um conjunto de princípios e regras em matéria de proteção e promoção de um ambiente saudável, equilibrado e seguro, reconhecendo o caráter vital da qualidade ambiental.

Mas os dados utilizados no primeiro capítulo mostram com clareza a atual situação de vulnerabilidade da biodiversidade brasileira.

A introdução de espécies exóticas contribuiu para a homogeneização dos ambientes, por isso necessita de planos de manejo e práticas preventivas adequadas para que se evite a disseminação de espécies.

O desmatamento, fenômeno pluricausal e com altos custos, altera os ecossistemas impactados que dificilmente serão restaurados. Faz-se necessário maior investimento em sistemas de monitoramento que abarquem todos os biomas do Brasil.

Práticas agrícolas menos danosas também devem ser estimuladas, como por exemplo, o uso controlado do fogo.

A fragmentação de habitats foi a ameaça à biodiversidade que recebeu destaque no trabalho em razão do seu potencial danoso e da necessidade de se repensar os instrumentos de políticas públicas para combatê-la. Ela esta fatalmente relacionada à dinâmica de uso da terra pelo homem, ocasionando a perda de espécies e de grupos funcionais em muitos lugares.

As ameaças à biodiversidade e a própria expansão da fronteira agrícola demonstram por suas consequências a real obrigação de se reformular as políticas públicas voltadas para a conservação da biodiversidade, a partir de estratégias que utilizem técnicas de indução de comportamentos coligadas com instrumentos de caráter coercitivo. 
A análise de políticas públicas relacionadas à biodiversidade permitiu inferir que algumas ações necessárias para a efetividade dos compromissos assumidos pelo Brasil na CDB e para a implementação da Política Nacional de Biodiversidade foram tomadas, mas para que estas medidas avancem e alcancem suas finalidades a adaptação do Plano Estratégico para a Biodiversidade 2011-2020 e das Metas de Aichi para o contexto nacional é fundamental.

A participação e discussão da sociedade brasileira é o que dará tônica a esse processo, assim é necessário que se crie ou se fortaleça os arranjos institucionais compatíveis com essa participação, de modo a assegurar legitimidade e sustentabilidade no cumprimento dos objetivos da CDB. Ademais, é fundamental definir os indicadores e metas com clareza para permitir o monitoramento dos avanços e a avaliação das estratégias e políticas públicas adotadas.

As ações governamentais derivadas das competências explicitadas pela Constituição Federal de 1988 para a conservação da biodiversidade, entre outras atribuições ambientais, ocorrem nos termos da Lei $n^{\circ} 6.938$ de 1981, que instituiu o SISNAMA, integrado por órgãos e entidades federais, estaduais, municipais e do Distrito Federal com atuação na área ambiental.

O mandamento constitucional insculpido no parágrafo único do art. 23, no qual é estabelecida, entre outras, a competência comum para a implementação das políticas públicas em meio ambiente impôs ao Congresso Nacional a elaboração de lei complementar, o que ocorreu por meio da Lei Complementar ${ }^{\circ} 140$ de 2011. Observase, contudo, que mesmo após a edição da referida norma dúvidas sobre as reais competências de cada ente ainda permanecem, ensejando insegurança jurídica e conflitos de competência. Faz-se importante a definição clara do papel dos entes federativos e dos instrumentos de cooperação entre eles, a fim de se impedir a duplicidade de ações, a ineficiência administrativa, o esperdício de recursos já insuficientes e a fragilização do sistema, com consequências deletérias a conservação da biodiversidade.

No que tange às medidas de proteção ecológica que devem ser levadas a efeito pelo Estado para a conservação da biodiversidade a Constituição de 1988, nos incisos do $\S 1^{\circ}$ do art. 225, estabelece de uma série deveres entre quais se destaca a definição em todas as unidades da Federação de espaços territoriais e seus componentes a serem especialmente protegidos, sendo a alteração e a supressão permitidas somente através de lei, vedada qualquer utilização que comprometa a integridade dos atributos que 
justifiquem sua proteção. Defende-se que os espaços territórios especialmente protegidos não constituem somente as unidades de conservação.

Em relação a estas últimas têm- se que o sistema de unidades de conservação é constituído pelo conjunto das unidades de conservação federais, estaduais e municipais e busca proteger os ecossistemas e promover o desenvolvimento sustentável. O SNUC é gerido pelo CONAMA, pelo MMA e por órgãos executores nos âmbitos federal (ICMbio), estadual e municipal. O sistema é organizado em torno de 12 categorias de manejo, consolidas em dois grupos de acordo com os objetivos de conservação grupo das unidades de conservação de proteção integral e o grupo de unidades de conservação de uso sustentável.

O sistema inova em alguns pontos a política de áreas protegidas no Brasil. Dentre suas principais inovações, destaca-se: a criação e administração mais participativa das UCs, que devem possuir instrumentos de planejamento (plano de manejo, zoneamento) e de gestão (conselhos) e a incorporação das propriedades privadas, como no caso das Reservas Particulares do Patrimônio Natural (RPPNs).

Por outro lado, o SNUC não resolveu problemas históricos das unidades de conservação, como a falta de implementação de uma série de unidades, a inefetividade de gestão, ausência de repasse de recursos e de planos de manejo efetivos.

Um primeiro passo para se superar as deficiências do sistema consiste no estabelecimento de critérios objetivos para a escolha das áreas para a conservação. Critérios estes que devem incorporar aspectos biológicos e não só políticos.

O segundo passo esbarra no planejamento da conservação, ou seja, o processo deve ser sistematizado incluindo etapas como: a definição de metas e indicadores de biodiversidade, a avaliação das áreas existentes e das prioritárias e a viabilização do manejo.

O terceiro passo diz respeito ao enfrentamento da questão fundiária, na medida em que o trabalho deve abranger agricultores, populações tradicionais e entes públicos.

O quarto passo a ser dado envolve a insuficiência de recursos destinados as áreas de conservação, o número de técnicos reduzidos, as deficiências operacionais do sistema e os incentivos negativos a instalação e manutenção das unidades. Enquanto a gestão das unidades de conservação não ganhar a importância que lhe é devida dentro das esferas estatais, estes problemas permanecerão.

A gestão eficiente das unidades e a expansão do número de áreas protegidas são a base e a principal estratégia de conservação, mas existem motivos para se supor que 
estas não são suficiente para garantir a conservação de ecossistemas, espécies, populações, que continuariam ameaçados pelos processos de destruição e fragmentação de hábitats, pela introdução de espécies exóticas e pela poluição. Um conhecimento maior da biodiversidade brasileira e o seu consequente monitoramento são urgentes para que qualquer estratégia de conservação seja bem sucedida.

Para tanto, incumbe enfatizar a importância de se investir em estudos baseados nas ciências da ecologia, da biologia, da biologia da conservação e das ciências humanas. Estratégias complementares podem e devem ser desenvolvidas visando combinar a conservação da biodiversidade com as necessidades humanas.

A biologia da conservação chama a atenção para a necessidade de áreas conectadas, vez que os processos ecológicos em geral necessitam de áreas extensas para se manterem e populações da flora e da fauna isoladas são mais vulneráveis as pressões externas, sendo susceptíveis a extinção.

Uma política eficiente de conservação da natureza requer o controle da perda e da fragmentação de hábitats. A perda e a fragmentação geram o declínio imediato da diversidade biológica e comprometem a sua manutenção futura, pela redução do tamanho das populações e pelo rompimento do fluxo gênico entre elas. As áreas com maior concentração de biodiversidade, como os hotspots, devem ser priorizadas, mas as demais regiões não podem ser negligenciadas.

Quando que se analisa as deficiências no processo de criação e implantação das unidades de conservação verifica-se que muitas vezes as unidades de conservação não estão integradas às políticas de desenvolvimento e uso da terra em nível regional ou local, desconsiderando os demais interesses em jogo. Ademais a política de criação e implantação de dissociadas de uma perspectiva mais abrangente da paisagem, não assegura a conservação em longo prazo da biodiversidade.

A eficácia dessa política depende da adoção de estratégias de gestão dos entorno das unidades de conservação. Como o isolamento dos fragmentos de floresta está avançando rapidamente as unidades de conservação e suas zonas-tampão não poderão, sozinhas, evitar o colapso das funções ecológicas e sua biodiversidade. Porém, mosaicos com múltiplos usos da terra em uma paisagem manejada podem permitir o movimento de populações por meio de "ligações" entre florestas próximas, motivo pelo qual cada vez mais se deve investir em redes de unidades de conservação conectadas às diversas áreas de interstício. 
Neste contexto, reconhece-se a maior eficácia das estratégias e ações de conservação da biodiversidade realizadas por meio de uma organização integrada e sistêmica. A integração das áreas protegidas na escala biorregional de planejamento e gestão é hoje, formalmente identificada através dos instrumentos reserva da biosfera, corredores ecológicos e mosaicos.

O Programa Homem e Biosfera contestou o dogma da separação entre o homem e a natureza ao propor formas de gestão integrada dos ecossistemas e promover o conhecimento, a prática e os valores humanos para implementar as boas relações entre as populações e o meio ambiente em todo o planeta. As Reservas da Biosfera são áreas de ecossistemas reconhecidas pelo programa $\mathrm{MAB}$ como importantes, em nível mundial, para a conservação da biodiversidade e o desenvolvimento sustentável.

A complexificação das formas de gestão integrada levou à instituição de formas de reconexão biológica conduzindo ao conceito de corredor como forma de planejar a conservação e a conectividade em larga escala envolvendo unidades de conservação e áreas de interstício submetidas a diferentes formas de uso da terra.

O mosaico, enquanto sistema de gestão integrada surge para proporcionar maior efetividade de governança das áreas protegidas, fortalecendo, também, as reservas da biosfera, aparece ainda como possível instrumento de ordenamento territorial em áreas de conflito entre unidades de conservação de proteção integral e população local.

Ademais, as áreas de preservação permanente e reserva legal constituem, outrossim, instrumentos fundamentais para uma gestão cada vez mais integrada da conservação da biodiversidade, que precisam ser garantidos. Buscou-se desta forma analisar mesmo que de maneira inicial e sintética o novo Código Florestal, Lei 12.651, de 25 de maio de 2012, com as modificações introduzidas pela Medida Provisória 571, de mesma data. Embora mantenha definições semelhantes de área de preservação permanente e de reserva legal, o Novo Código introduziu em seus dispositivos uma série de medidas reducionistas que não levam à conservação da biodiversidade.

O Novo Código Florestal trata das questões florestais sob dois prismas, um mais brando para as condutas lesivas levadas a cabo até o dia 22 de julho de 2008 e um mais duro para as condutas efetuadas após esta data.

Mudanças como as relacionadas à delimitação das áreas de preservação permanente, que passam a serem medidas a partir da borda do leito regular, como a possibilidade de cômputo de áreas de preservação permanentes conservadas ou em processo de recuperação nas áreas de reserva legal e como a compensação das áreas de 
reserva legal no mesmo bioma flexibilizaram as normas referentes a estas áreas, contrariando orientações científicas, colocando em risco a biodiversidade e os serviços ecossistêmicos que dependem desta última para sua manutenção e estabelecendo um padrão ambiental notadamente inferior ao anterior.

A presente dissertação buscou ainda elaborar apontamentos iniciais acerca da função promocional do Direito Ambiental, ou seja, a utilização de mecanismos de incentivo como forma de concretizar o direito fundamental ao meio ambiente ecologicamente equilibrado, tendo em vista a insuficiência da utilização exclusiva de mecanismos de comando e controle, tal como tradicionalmente previsto pela legislação pátria.

O tema revela-se atual e importante, notadamente diante do recente crescimento do debate acerca dos pagamentos por serviços ambientais, tanto no âmbito nacional quanto internacional, sendo certo que o aprofundamento da compreensão teórica e prática sobre a matéria consubstancia importante elemento para a adequada criação e aplicação de tais instrumentos de promoção da conservação da biodiversidade.

Os pagamentos por serviços ambientais podem ser classificados de diversas maneiras. Os PSA's puros possuem como características a voluntariedade, a definição clara dos serviços ambientais, pelo menos um comprador e um vendedor, e a transferência de recursos condicionada a entrega do serviço ambiental. Já os PSA's entendidos de maneira mais ampla, são todos aqueles que envolvem algum tipo de pagamento para a provisão dos serviços ambientais. Os pagamentos por serviços ambientais também podem ser classificados de acordo com o nível de intervenção governamental.

Como os pagamentos por serviços ambientais envolvem estudos interdisciplinares fez-se necessário para maior compreensão do tema lançar mão, por exemplo, do conceitual teórico de algumas escolas econômicas que tratam das questões ambientais.

A economia ecológica contribui para a temática dos PSA's na medida em que chama a atenção para a capacidade de suporte dos ecossistemas e para o imperativo de valorizá-los.

A teoria das externalidades advinda da economia ambiental também contribui para a fundamentação dos programas e os estudos institucionalistas a desenhar e analisar os papéis que cada stakeholder tem nos programas. 
Embora não exista uma receita única para conceber programas de pagamento por serviços ambientais, já que a estratégia sempre deve estar adaptada a realidade alguns fatores importantes precisam ser analisados.

Quando se fala nestes pagamentos deve se verificar se o mesmo é o mais adequado para se atingir os objetivos ambientais desejados, se a melhora dos serviços ambientais é maior que o seu custo de implantação, mas ainda é preciso estar-se ciente de que o PSA exige a criação de espaços interinstitucionais de participação.

Além do mais é preciso acompanhar o processo de desenvolvimento do programa que como sugestão deve englobar as fases de diagnóstico, desenho e implantação.

Constatou-se, que os pagamentos por serviços ambientais relacionados à biodiversidade, embora, promissores ainda são incipientes, isso provavelmente decorre da característica de bens públicos quase puros dos serviços da biodiversidade e das dificuldades metodológicas em se calcular efetivamente qual a contribuição de cada uso de terra para provimento de serviços ambientais. Definir como os serviços ambientais serão monitorados e consequentemente como serão comprovados os benefícios das atividades que proveem os serviços ambientais ainda revelam-se como um desafio, carecendo de definição e de estudos mais específicos. Esta dificuldade técnica está relacionada à variabilidade e heterogeneidade intrínseca dos sistemas ecológicos.

Lado outro, programas como o PROMATA demonstram que a gestão integrada da biodiversidade, embora necessite de aperfeiçoamento e planejamento segundo a realidade local, tem sido eficiente na conservação da biodiversidade. O programa foi feito com apoio dos agricultores e buscou aumentar a conectividade entre fragmentos florestais de origem nativa, formando corredores de biodiversidade.

O PROMATA desenvolveu-se de acordo com cinco estratégias, dentre as quais se destaca o fortalecimento das unidades de conservação através da elaboração de planos de manejo, que procuraram enfatizar os aspectos gerenciais, com o intuito de melhor atender à administração das unidades e fomentar participação da comunidade no processo de gestão dos parques e na adoção de práticas sustentáveis em suas áreas de entorno e de conectividade.

Outra estratégia que merece destaque teve como objetivo o incentivo a recomposição e a regeneração da floresta e a promoção da conectividade entre os remanescentes de Mata Atlântica no entorno das Unidades de Conservação, através da instituição de um incentivo financeiro para os agricultores engajados, como pagamento 
pelos serviços ambientais por eles prestados ao recuperar a floresta em suas propriedades.

O que se verifica, portanto, é que o PROMATA na estratégia de pagamento aos agricultores, pelo menos no plano teórico, possuía os requisitos para ser um bom programa, já que na fase de diagnóstico foram feitos estudos específicos para averiguar os problemas e assim serem traçadas as estratégias. O objetivo claro do programa fez com que o PSA fosse direcionado para as localidades nas quais era necessário, evitandose assim os altos custos de transação. E, a participação dos agricultores conjuntamente com as diversas entidades públicas e privadas favorece o fortalecimento da participação.

A descontinuidade do programa aliada a falta de clareza quanto aos cálculos de custo de oportunidade que deram origem aos valores dos pagamentos forma alguns dos problemas detectados.

De maneira geral, o PROMATA possuiu bom desenho vez que atacava os principais problemas das unidades de conservação diagnosticados neste trabalho, fomentava a recuperação de áreas degradadas, colocava em relevo as áreas de preservação permanente e reserva legal, tinha o intuito de formar corredores e utilizavase dos pagamentos por serviços ambientais para atingir seu objetivo quando os demais instrumentos não revelavam-se suficientes.

Conclui-se, a vista de todo o exposto que qualquer instrumento individual para a conservação da biodiversidade possui pontos fortes e fracos e a elaboração de uma boa estratégia incidirá sobre qual o instrumento mais adequado para atingir um objetivo, podendo utilizar instrumentos adicionais e complementares para compensar os pontos fracos de instrumentos individuais.

Face às dificuldades de se lidar com a matéria ambiental um mix de instrumentos de políticas pode garantir, com maior eficácia e eficiência, a proteção da biodiversidade, pois abordam vários objetivos e estratégias.

Essas estratégias envolvem intervenções diretas nas atividades humanas, notadamente nas formas como extraímos e exploramos os recursos naturais. Portanto, a conservação da biodiversidade, por definição, indica restrições ou adequações ao desenvolvimento das atividades produtivas, a exploração do solo, a construção de infraestrutura e ao regime de uso da propriedade privada e pública. 


\section{Referências Bibliográficas}

ANDRADE, Daniel Caixeta; BORGES, Lucas Marins de Camargos. A utilização de policy mix em arranjos de política ambiental: notas preliminares. IX Encontro Nacional da ECOECO. Brasília, 2011.

AHRENS, Sergio. O Código Florestal Brasileiro no século XXI: Histórico, Fundamentos e Perspectivas. IN FIGUEIREDO, Guilherme J. P.; SILVA, Lindamir M.; RODRIGUES, Marcelo A ; LEUZINGER, Márcia D. (Org.). Código Florestal 45 anos. Estudos e Reflexões. $1^{\text {a }}$. ed. Curitiba: Letra da lei, 2010, p. 63-82.

ALTAMANN, Alexandre. Pagamento por serviços ambientais: aspectos jurídicos para a sua aplicação no Brasil. In. Anais do Congresso Internacional de Direito Ambiental: Florestas, Mudanças Climáticas e Serviços Ecológicos. (Coords.).BENJAMIN, Antônio Herman Et. Al.. São Paulo: Imprensa Oficial do Estado de São Paulo, 2010.

ALTMANN, Alexandre. Pagamento por serviços ecológicos: uma estratégia para a restauração e preservação da mata ciliar no Brasil?. Caxias do Sul: UNICS, 2008, p.60. Originalmente apresentada como dissertação de mestrado. Universidade de Caxias do Sul, RS, 2008.

ALTAMANN, Alexandre. A função promocional do direito e o pagamento pelos serviços ecológicos. Revista de direito ambiental 52, 2008, p.11-26.

ANTUNES. Paulo de Bessa. Direito Ambiental. 14 ed.- São Paulo: Atlas, 2012.

AYALA, Patríck de Araújo. Deveres ecológicos da atividade econômica na Constituição Brasileira. Direito Constitucional Brasileiro. José Joaquim Canotilho, José Rubens Morato Leite (org.). São Paulo: Saraiva, 2007, p.262 -316.

BECCA, M.; CARROL, N. und MOORE BRANDS, K. State of Biodiversity Markets Report: Offset and Compensation Programs Worldwide. Disponível em:

http://www.ecosystemmarketplace.com/documents/ acrobat/sbdmr.pdf, 2010.

BENSUSAN, Nurit. Conservação da biodiversidade em áreas protegidas. Reimpressão. Rio de Janeiro: FGV, 2006, p.14.

BOBBIO, Norberto. Da estrutura à função: novos estudos da teoria do direito. Tradução de Daniela Beccaria Versiani. Barueri: Manole, 2008.

BRASIL. Ministério do Meio Ambiente. Secretaria de Coordenação da Amazônia. Instituto Brasileiro do Meio Ambiente e dos Recursos Naturais Renováveis. Programa piloto para a proteção das florestas tropicais do Brasil: PPG7, projeto corredores ecológicos. Brasílai: MMA, 2001.

BUCCI, Maria Paula Dallari. Notas para uma metodologia de análise de políticas públicas. In: Fortini, Cristiana; Esteves, Júlio César dos Santos; Dias, Maria Tereza Fonseca (Org.). Políticas públicas possibilidades e limites. Belo Horizonte: Editora Fórum, 2008, p.225-260. 
BUCCI, Maria Paula Dallari. O conceito de política pública em direito. Políticas Públicas e Ciência Política.Políticas públicas: reflexões sobre os conceito jurídico/ Maria Paula Dallari Bucci (organizadora)- São Paulo: Saraiva. 2006.

CAMARA DOS DEBUTADOS. Conservação da Biodiversidade: Legislação e Políticas Públicas. Ganem, Roseli Senna (org.). 2011.

CAVALCANTI, C. Uma tentativa de caracterização da economia ecológica. Ambiente \& Sociedade, v. 7, n. 1, p.149-156, jan./jun. 2004. Disponível em: http://www.scielo.br/pdf/asoc/v7n1/23541.pdf.

CAVALCANTI, Roberto Brandão. Estratégias de conservação em nível regional: priorização de áreas e corredores de biodiversidade. In: ROCHA, C. F. D.; BERGALLO, H. G.; SLUYS, M. Van; ALVES, M. A. S. Biologia da conservação: essências. São Carlos: Rima, 2006. p. 350351.

CERQUEIRA, R.; BRANT, A.; NASCIMENTO, M. T. \& PARDINI, R. Fragmentação: alguns conceitos. In: RAMBALDI, D. M.; OLIVEIRA, D. A. S. (orgs.). Fragmentação de ecossistemas: causas, efeitos sobre a biodiversidade e recomendações de políticas públicas. Brasília: MMA, SBF. 2003. p. 23-40.

CHIQUITO, Ailton. Pagamento por serviços ambientais: aspectos legais. Dissertação de Mestrado. Marília. 2012.

CIPRIANO.Tasso Richetti, Pires. A reforma do Código Florestal Brasileiro. Prelo. São Paulo.2011.

CONSTANZA, Robert et al. The value of the world's ecosystem services and natural capital. In Nature,v.387,issue 6630,1997,p.254. Apud NUSDEO, Ana Maria de Oliveira. Pagamento por serviços ambientais no Brasil: elementos para uma regulamentação ambientalmente íntegra e socialmente justa. Tese de Livre-Docência. São Paulo. 2010.p 80

COASE, Ronald. The problem of social cost. Journal of Law and Economics, v.3, Oct 1960.

DALY, H. E. Crescimento sustentável? Não, obrigado. Ambiente \& Sociedade (on line), v. 7, n. 2,p. 197-202, 2004. Disponível em: http://www.scielo.br/pdf/asoc/v7n2/24695.pdf.

DAILY, G.C. (Ed.) Nature's Services: Societal Dependence on Natural Ecosystems. Washington, DC: Island Press, 1997.

DOUROJEANNI, Marc Jean, PÁDUA, Maria Tereza Jorge. Biodiversidade a hora decisiva. $2^{\mathrm{a}}$ ed. Curitiba: UFPR, 2007.

FERREIRA, Heline Sivini. Política Ambiental Constitucional. Direito Constitucional Brasileiro. José Joaquim Canotilho, José Rubens Morato Leite (org.). São Paulo: Saraiva, 2007.

FISZON, Judith, Tiommy. et. al. Causas Antrópicas. In: RAMBALDI, D. M.; OLIVEIRA, D. A. S. (orgs.). Fragmentação de ecossistemas: causas, efeitos sobre a biodiversidade e recomendações de políticas públicas. Brasília: MMA, SBF. 2003.p.65-101. 
GANEM, Sueli Senna. Gestão integrada da biodiversidade: corredores, mosaicos e reservas de biosfera. In GANEM, Roseli Senna (org.).Conservação da biodiversidade: legislação e políticas públicas / -Brasília : Câmara dos Deputados, Edições Câmara, (Série memória e análise de leis ; n. 2). 2011.

GANEM, Roseli Senna (org.).Conservação da biodiversidade: legislação e políticas públicas / Brasília : Câmara dos Deputados, Edições Câmara, (Série memória e análise de leis ; n. 2). 2011.

GANEM, Roseli Senna. Políticas de conservação da biodiversidade e conectividade entre remanescentes de cerrado. 2007. 431 f., il. Tese (Doutorado em Desenvolvimento Sustentável)UnB, Brasília, 2007.

GANEM, Roseli Senna. Corredores ecológicos. Câmara dos Deputados. 2005.

GANEM, Roseli Senna, Drummont, José Augusto. Biologia da Conservação: as bases científicas da conservação. In GANEM, Roseli Senna (org.).Conservação da biodiversidade: legislação e políticas públicas / -Brasília : Câmara dos Deputados, Edições Câmara, (Série memória e análise de leis ; n. 2). 2011.

GRANZIERA, Maria Luiza Machado. Direito Ambiental. 2a ed. rev .at. São Paulo: Atlas, 2011.

HERCOWITZ, Marcelo et al. Estudo de casos sobre serviços ambientais. In NOVION, Henry e VALLE, Raul. É pagando que se preserva? São Paulo: Instituto Socioambiental, Documentos ISA no. 10, 2009.

JOLY, Carlos A., METZGER, Jean Paul, CASSATI, Lilian, MARTINELLI, Luiz, RODRIGUES, Ricardo R. e LEWINSOHN, Thomas M. Impactos potenciais das alterações propostas para o Código Florestal Brasileiro. p. 5. 2011. Disponível em: http://www2.unesp.br/revista/wp-content/uploads/2010/10/Biota-Fapesp-ABECO-Sintese-CFBe-biodiversidade.pdf.

JURAS, I. A. G. M. Instrumentos para conservação da biodiversidade. In GANEM, Roseli Senna (org.).Conservação da biodiversidade: legislação e políticas públicas / -Brasília : Câmara dos Deputados, Edições Câmara, (Série memória e análise de leis ; n. 2). 2011.p.223-284.

JURAS, I. A. G. M. Uso de instrumentos econômicos para a gestão ambiental: países da OCDE e América Latina. Câmara dos Deputados, Consultoria Legislativa, 2009. Disponível em: http://bd.camara.gov.br/bd/handle/bdcamara/1025.

JURAS, I. A. G. M.; ARAÚJO, S. M. V. G. Instrumentos econômicos de política ambiental e reforma tributária. Cadernos Aslegis, Brasília, n. 33, 2008, p. 109-127.

LANDELL-MILLS, N.; PORRAS, I.T. Silver bullet or fools' gold? A global review of markets for forest environmental services and their impacts on the poor. London: International Institute for Environment and Development - IIED, 2002 
LERNER, Lucy Claudia. Convenção da Diversidade Biológica- Compromisso assumidos e resultados obtidos pelo Brasil. Disponível em:

http://www.google.com.br/url?sa=t\&rct=j\&q=LERNER\%2C+Lucy+Claudia.+Conven\%C3\%A $7 \% \mathrm{C} 3 \% \mathrm{~A} 3 \mathrm{o}+\mathrm{da}+$ Diversidade+Biol\%C3\%B3gica+Compromisso+assumidos+e+resultados+obti dos+pelo+Brasil.\&source $=$ web $\& c d=1 \& v e d=0 \mathrm{CDMQFj} A A \& u r l=h t t p \% 3 \mathrm{~A} \% 2 \mathrm{~F} \% 2 \mathrm{Fwww}$.anppa s.org.br\%2Fencontro_anual\%2Fencontro3\%2Farquivos\%2FTA20403032006163000.DOC\&ei= Ap3PUIWLMtO40AGrrIGIAg\&usg=AFQjCNEfWtdQKUEe3BWjPEBUkUf9Pp0bbw\&bvm= bv.1355325884,d.dmQ Acesso em: 17 dez.2012.

MA. Millenium Ecosystem Assessment. Ecosystems and Human Well-being: Synthesis. Washington DC. Disponível em português em: http://www.maweb.org/documents/document.446.aspx.pdf: IslandPress, 2005

MACHADO, Paulo Affonso Leme. Direito ambiental brasileiro. São Paulo: Malheiros, 2005.

MACIEL, Bruno de Amorim. Mosaicos de Unidades de Conservação: uma estratégia de conservação para a Mata Atlântica. Dissertação de Mestrado. Centro de Desenvolvimento sustentável, Universidade de Brasília, Brasília. 2007.

MAGALHÃES, Vladimir Garcia, O código florestal e o aquecimento global, in Paula Lavratti e Vanêsca Buzelato Prestes, Direitos e mudanças climáticas, 4 - Reforma do código florestal: limites jurídicos, São Paulo, Instituto o Direito por um Planeta Verde, 2010, p.59. Disponível em: http://www.observatorioeco.com.br/wp-content/uploads/up/2010/12/cadigo-florestal.pdf.

MASSA- ARZABE, Patrícia Helena . Políticas públicas sociais: aspectos da dimensão jurídica. APUD Gonçalves Alcindo.Políticas Públicas e Ciência Política.Políticas públicas: reflexões sobre os conceito jurídico/ Maria Paula Dallari Bucci (organizadora)- São Paulo: Saraiva. 2006.

MARTÍNEZ-ALIER, J. Da economia ecológica ao ecologismo popular. Blumenau: Ed. da FURB,1998.

MAY, P.H. Economia Ecológica e o Desenvolvimento Equitativo no Brasil. In: MAY, P.H. (Ed.) Economia Ecológica: Aplicações no Brasil. Rio de Janeiro: Campus, 1995.Cap. 1, p. 1-20.

MEDEIROS, Rodrigo. YOUNG, Carlos Eduardo Frickmann (Ed.).Contribuição das unidades de conservação brasileiras para a economia nacional: Relatório Final - Brasília: UNEP-WCMC, 2011.

METZGER, Jean Paul. CASSATI, Lilian. Do diagnóstico à conservação da biodiversidade: o estado da arte do programa BIOTA/FAPESP. Biota Neotropica v6. $\mathrm{n}^{\circ} 2$. Disponível em: < http://www.biotaneotropica.org.br/v6n2/pt/abstract?point-of-view+bn00106022006>.

MINISTERIO DO MEIO AMBIENTE. Quarto relatório nacional para a convenção sobre diversidade biológica: Brasil /Ministério do Meio Ambiente. Brasília: MMA, 2011.

MINISTERIO DO MEIO AMBIENTE, IBAMA .I Seminário sobre Corredores Ecológicos no Brasil: Nota Técnica, 2001. 10 p. 
MOTTA, Ronaldo Seroa. A estimativa do custo econômico do desmatamento na Amazônia. IPEA, 2011.

NUSDEO, Ana Maria de Oliveira. Pagamentos por serviços ambientais no Brasil: Elementos para uma regulamentação ambientalmente íntegra e socialmente justa. Tese de Livre Docência. São Paulo, 2010.

NUSDEO, Ana Maria. O papel dos mercados e dos direitos de propriedade na proteção ambiental. Disponível em:< http://www.law.yale.edu/documents/pedf/sela/Nusdeo_porthuguese

PÁDUA, Maria Tereza Jorge. Do Sistema Nacional de Unidades de Conservação. In Dez anos do Sistema Nacional de Unidades de Conservação da Natureza: lições do passado, realizações presentes e perspectivas para o futuro / Rodrigo Medeiros, Fábio França Silva Araújo; Organizadores. - Brasília: MMA, 2011, p. 21-36.

PAGIOLA, S.; PLATAIS, G. Payments for Environmental Services: From Theory to Practice. Washington: World Bank, 2007. APUD GUEDES, Fátima Becker. SEEHUSEN, Susan Edda. Org. Pagamentos por Serviços Ambientais na Mata Atlânica: lições aprendidas e desafios. Brasília: MMA, 2011.

PERU. MINAM. Compensación por servicios ecosistémicos: Lecciones aprendidas de una experiência demonstrativa. Las microcuencas Mishiquiyacu, Rumiacu y Almendra de San Martín, Peru. Lima:Ministerio del Ambiente, 2010.APUD GUEDES, Fátima Becker.

SEEHUSEN, Susan Edda. Org. Pagamentos por Serviços Ambientais na Mata Atlânica: lições aprendidas e desafios. Brasília: MMA, 2011.

PEREIRA, Osny Duarte.Direito Florestal Brasileiro. Rio de Janeiro: Borsoi, 1950.

PRIMACK, Richard B., RODRIGUES, Efraim. Biologia da Conservação. Londrina: Rodrigues. 2001.

POWELL, I.; WHITE, A. Conceptual Framework - Developing Markets and Market-Based Instruments for Environment Services of Forests. Washington, D.C.:Forest Trends, 2001. Katoomba Group. Disponível em: <HTTP://www.foresttrends.org>.APUD VEIGA NETO, Fernando César da. A construção de serviços ambientais e suas implicações para o desenvolvimento no Brasil. Tese de Doutorado - Universidade Federal do Rio de Janeiro, Instituto de Ciências Humanas e Sociais. Rio de Janeiro. 2008.

RANIERE, Victor Eduardo Lima. Passado, presente e futuro do Sistema Nacional de Unidades de Conservação: uma síntese dos resultados do seminário nacional. In Dez anos do Sistema Nacional de Unidades de Conservação da Natureza: lições do passado, realizações presentes e perspectivas para o futuro / Rodrigo Medeiros, Fábio França Silva Araújo; Organizadores. Brasília: MMA, 2011, p. 149-163.

RAMBALDI, D. M.; OLIVEIRA, D. A. S. (org.). Fragmentação de ecossistemas: causas, efeitos sobre a biodiversidade e recomendaçoes de políticas públicas. Brasília: MMA/ SBF, 2003. p. 367- 389. 
RESENDE, Keila Maria. Legislação Florestal Brasileira: Uma Reconstituição Histórica. Dissertação apresentada à Universidade Federal de Lavras. Lavras, 2006.

ROMEIRO, Ademar; MAIA, Alexandre Gori.Avaliação dos custos e benefícios ambientais. Brasília: ENAP, 2011.

RODRIGUES, Marta M. Assumpção. Políticas públicas. São Paulo: Publifolha, 2010.

SCARIOT, A.; FREITAS, S. R. de; NETO, E. M.; NASCIMENTO, M. T.; OLIVEIRA, L. C. de; SANAIOTTI, T.; SEVILLA, A. C.; VILLELA, D. M. In: RAMBALDI, D. M.; OLIVEIRA, D. A. S. (org.). Fragmentação de ecossistemas: causas, efeitos sobre a biodiversidade e recomendaçoes de políticas públicas. Brasília: MMA/SBF, 2003. p. 103-123.

SEEHUSEN ,Susan Edda; CUNHA, André A., OLIVEIRA JUNIOR , Arnaldo Freitas de. Iniciativas de PSA para a proteção da biodiversidade na Mata Atlântica. GUEDES, Fátima Becker. SEEHUSEN, Susan Edda. Org. Pagamentos por Serviços Ambientais na Mata Atlânica: lições aprendidas e desafios. Brasília: MMA, 2011.p. 184 a 214.

SEMAD. Relatório Final. Projeto de Proteção da Mata Atlântica em Minas Gerais. 2009.

SOUZA, Gláucia Cardoso de. Economia Ecológica e Sustentabilidade Socioambiental. Florianópolis: V Encontro Nacional da Anppas, 2010.

SILVA, José Afonso. Direito Ambiental Constitucional. São Paulo: Malheiros, 2010.

UICN, WWF-BRASIL e IPÊ. Metas de Aichi: Situação atual no Brasil. Ronaldo Weigand Jr; Danielle Calandino da Silva; Daniela de Oliveira e Silva. Brasília: UICN, WWF-Brasi e IPÊ, 2011.

VEIGA NETO, Fernando César da. A construção de serviços ambientais e suas implicações para o desenvolvimento no Brasil. Tese de Doutorado - Universidade Federal do Rio de Janeiro, Instituto de Ciências Humanas e Sociais. Rio de Janeiro. 2008.

VEIGA NETO, Fernando César da. Análise de Incentivos Econômicos nas Políticas Públicas para o Meio Ambiente - O caso do "ICMS Ecológico" em Minas Gerais. 2000. $161 \mathrm{f}$. Dissertação (Mestrado em Desenvolvimento, Agricultura e Sociedade) - CPDA, ICHS, Universidade Federal Rural do Rio de Janeiro, Rio de Janeiro, 2000.

VEIGA NETO, Fernando César da. Usando mecanismos de compensação fiscal para incentivar a conservação da biodiversidade: o ICMS ecológico. In: SEMINÁRIO ICMS ECOLÓGICO: DIAGNÓSTICO E PERSPECTIVAS, 2004, Brasília. [Anais...]. Brasília: Comissão de Meio Ambiente e Desenvolvimento Sustentável da Câmara dos Deputados; Secretaria de Políticas Públicas para o Desenvolvimento Sustentável do MMA, 2004.

VIANA, Maurício Boratto. A contribuição parlamentar para a política florestal no Brasil. Câmara dos Deputados, Consultoria Legislativa. 2004, p.07. Disponível em http:// nbd.camara.gov.br/bd/handle/bdcamara/1203. Acessado em: 08 de julho de 2013. 
WUNDER, Sven. Payments for environmental services: some nuts and bolts. Center for internacional forestry research - CIFOR. (2005). Disponível em:

http://www.cifor.org/publications/pdf_files/OccPapers/OP-42.pdf

YOUNG, C. E. F. Socioeconomic causes of deforestation in the Atlantic Forest of Brazil. In: Atlantic Forest: biodiversity status, threats, and outlook. C. Galindo-Leal \& I. G. Câmara (eds). Washington, D.C., USA: Island Press, 2003. p. 103-117. 